\title{
Mariusz Chrostek
}

ORCID 0000-0003-4679-796X

Uniwersytet Rzeszowski, Instytut Polonistyki i Dziennikarstwa

(Rzeszów, Polska)

mchrostek@ur.edu.pl

\section{Przełomowe osiągnięcia lwowskich filologów w badaniach polskiego romantyzmu do roku 1939}

\begin{abstract}
Abstrakt
Celem artykułu jest pokazanie wyjątkowych zasług polskich literaturoznawców związanych ze Lwowem w badaniach romantyzmu na tle osiągnięć uczonych z innych polskich uniwersytetów. Analizowany problem obejmuje okres do roku 1939, ponieważ dotąd funkcjonował we Lwowie polski uniwersytet. Zainteresowanie rodzimym romantyzmem, zwłaszcza trójcą wieszczów: Adamem Mickiewiczem, Juliuszem Słowackim i Zygmuntem Krasińskim, dominowało w pracach naukowych filologów epoki pozytywizmu, Młodej Polski i dwudziestolecia międzywojennego. Porównanie dorobku Lwowa z „resztą Polski” obejmuje monografie największych pisarzy i ich ocenę, rozprawy i artykuły oraz stosowaną w badaniach metodologię. W czasach zaborów
\end{abstract}

\begin{tabular}{|c|c|c|c|c|c|}
\hline \multicolumn{2}{|c|}{$\begin{array}{l}\text { INFORMACJA } \\
\text { O PUBLIKACJI }\end{array}$} & Pistoriae & $\begin{array}{r}\text { e-ISSN 2543-702X } \\
\text { ISSN 2451-3202 }\end{array}$ & 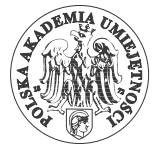 & $\begin{array}{l}\text { } \\
\text { BRYLANTOWY MODEL } \\
\text { OTWARTEGO DOSTĘPU }\end{array}$ \\
\hline \multicolumn{6}{|c|}{$\begin{array}{l}\text { CYTOWANIE } \\
\text { Chrostek, Mariusz 2021: Przełomowe osiągnięcia Iwowskich filologów w badaniach polskiego romantyzmu } \\
\text { do roku 1939. Studia Historiae Scientiarum 20, ss. 87-166. DOI: } \underline{10.4467 / 2543702 X S H S .21 .005 .14036} \text {. }\end{array}$} \\
\hline \multicolumn{3}{|c|}{$\begin{array}{l}\text { OTRZYMANO: } 05.12 .2020 \\
\text { ZAAKCEPTOWANO: } 11.07 .2021 \\
\text { OPUBLIKOWANO ONLINE: } 13.09 .2021\end{array}$} & $\begin{array}{l}\text { POLITYKA } \\
\text { ARCHIWIZOWANIA } \\
\text { Green SHERPA/ } \\
\text { RoMEO Colour }\end{array}$ & 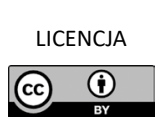 & $\begin{array}{l}\text { CrOSSTe' } \\
\text { Similarity Check } \\
\text { Powered by ithenticate }\end{array}$ \\
\hline WWW & \multicolumn{5}{|c|}{ https://ojs.ejournals.eu/SHS/; http://pau.krakow.pl/Studia-Historiae-Scientiarum/archiwum } \\
\hline
\end{tabular}


(do 1918 r.) poloniści lwowscy konkurowali głównie z krakowskimi (UJ) i kilkoma z Warszawy. W Krakowie powstało najwięcej monografii trzech wieszczów, ale to we Lwowie Juliusz Kleiner napisał najlepszą (o Krasińskim). Filolodzy krakowscy stosowali przestarzałą metodologię (oceniali literaturę ze względu na poglądy ideologiczne pisarzy, nie interpretowali samych dzieł). We Lwowie badano głównie teksty utworów literackich, ich wartość artystyczna. Przed rokiem 1914 Juliusz Kleiner stworzył nowoczesną metodologię (dzieło literackie w centrum zainteresowań). Sformułował też pojęcie epoki romantyzmu, które przyswoili potem inni uczeni. Poglądy Kleinera stały się podstawą w badaniach literatury w dwudziestoleciu międzywojennym.

W wolnej Polsce w latach 1919-1939 działało sześć uniwersytetów: we Lwowie, Krakowie, Warszawie, Wilnie, Lublinie i Poznaniu. Polonistyka we Lwowie przeżywała wtedy okres największej świetności. To kolejne zasługi wybitnego Juliusza Kleinera, uznawane za najlepsze w Polsce i ponadczasowe: dwie ogromne monografie - Słowackiego i Mickiewicza, znakomicie opracowane Dżieła wszystkie Słowackiego (większość tomów), historia literatury polskiej po polsku i niemiecku i inne. We Lwowie pracował Eugeniusz Kucharski - najlepszy w Polsce znawca Aleksandra Fredry; Konstanty Wojciechowski i Zygmunt Szweykowski - najwybitniejsi specjaliści od polskiej powieści. We Lwowie działało od 1886 r. Towarzystwo Literackie im. Adama Mickiewicza (w innych miastach po roku 1919 jego filie). Tam też ukazywał się „Pamiętnik Literacki” - najbardziej zasłużone czasopismo badaczy literatury. W porównaniu z pozostałymi miastami we Lwowie najliczniejsza grupa uczonych badała polski romantyzm i poświęciła mu najwięcej publikacji.

Słowa kluczowe: Uniwersytet Lwowski, Uniwersytet Jana Kazimierza, polonistyka lwowska, Juliusz. Kleiner, Eugeniusz Kucharski, monografie trzech wieszczón, polski romantyzm, badanie romantyzmu, polscy literaturoznawcy do 1939 roku, historia literatury 


\title{
The groundbreaking achievements of Lviv philologists in the study of Polish Romanticism until 1939
}

\begin{abstract}
The aim of the article is to show the exceptional merits of Polish Lviv-affiliated literary scholars in the study of Romanticism against the background of the achievements of scholars from other Polish universities. The analyzed problem covers the period until 1939, as this was when the Polish university in Lviv ceased to function. Interest in native Romanticism, especially in the three poet-prophets: Adam Mickiewicz, Juliusz Słowacki and Zygmunt Krasiński, was central to the work of positivist, Young-Poland and interwar-period philologists. The comparison of the achievements of Lviv with the "rest of Poland" includes monographs by the greatest authors along with their evaluation, dissertations and articles, as well as the methodology used in the research. During the Partitions of Poland (that is, until 1918), Polish studies experts from Lviv competed mainly with those from Kraków (Jagiellonian University) and several others from Warsaw. Most of the monographs on the three poet-prophets were written in Kraków, but it was in Lviv where Juliusz Kleiner wrote the best of them (on Krasiński). Kraków philologists would rely on an outdated methodology (they assessed literature on the basis of the ideological views of writers, without interpreting the works themselves). Meanwhile in Lviv, it was the text of the literary works and its artistic value that were mainly explored. Before 1914, Juliusz Kleiner developed a modern methodology (a literary work in the center of interest) and formulated the concept of the period of Romanticism that was later adopted by other scholars. Kleiner's views became the basis for research into interwar literature.

In the Second Polish Republic (1919-1939), there were six active universities: in Lviv, Kraków, Warsaw, Vilnius, Lublin, and Poznań. At that time, the field of Polish studies in Lviv was at its zenith, owing largely to the further outstanding achievements of Juliusz Kleiner, which were considered the best in Poland and timeless. They include, among others: two extensive monographs on Słowacki and Mickiewicz, the excellently compiled Complete
\end{abstract}


Workes of Juliusz Stowacki (most volumes), or the history of Polish literature released in Polish and German. In addition, Lviv was the place of work for Eugeniusz Kucharski, prominent expert on Aleksander Fredro in Poland, as well as for Konstanty Wojciechowski and Zygmunt Szweykowski, both eminent specialists in Polish novels. The city was also the place where the Adam Mickiewicz Literary Society was active since 1886 (it branched out into other cities after 1919) and the place of publication of Pamietnik Literacki, the most distinguished literary research journal. Compared to other cities, Lviv gathered the largest group of scholars who studied Polish Romanticism and who devoted the greatest number of publications to it.

Keywords: University of Lviv, Jan Kazimierz University, Lviv Polish Studies, Juliusz. Kleiner, Eugeniusz. Kucharski, monographs of the three poet-prophets, Polish Romanticism, study of Romanticism, Polish literary studies until 1939, bistory of literature

\section{Literaturoznawcy wobec dziedzictwa romantyzmu}

W badaniach polskich historyków literatury romantyzm zajmował uprzywilejowane miejsce, odkąd tylko starano się go objać naukową refleksja, to znaczy od lat 60 . XIX wieku, kiedy po upadku powstania styczniowego stał się on zamkniętą epoką literacką i formacją kulturowa. Taki stan rzeczy utrzymywał się co najmniej do roku 1939. Pogrążone w niewoli kolejne pokolenia Polaków rozumiały i doceniały wyjątkowość tej epoki, która w Polsce była - jak to określiła Maria Janion - „bardzo kunsztownie obmyślonym i bardzo głęboko uwewnętrznionym sposobem ocalenia ojczyzny". Dzieła literackie, zwłaszcza poezja stworzona przez najwybitniejszych przedstawicieli, wieszczów, podnosiła cierpienia narodu poprzez mesjanistyczną analogię do rangi męczeńskiej śmierci Chrystusa, z patriotyzmu czyniła rodzaj ofiary i szczególnego posłannictwa. Nic dziwnego, że uważano ją niemal za narodową ewangelię, tym bardziej cenioną, że zakazana pod zaborem rosyjskim i pruskim.

Wychowani na lekturze utworów Adama Mickiewicza, Juliusza Słowackiego czy Zygmunta Krasińskiego młodzi pozytywiści potraktowali tę niezwykłą spuściznę jak duchowe dziedzictwo, jak zbiór wskazań

1 Janion 1986, s. 118. 
moralnych, zestaw haseł patriotycznych, wreszcie ideowy przewodnik dla narodu, aktualny dopóty, dopóki nie odzyskał on niepodległości. Badając tak niezwykły dorobek minionej epoki, w pewnym sensie czuli się jego strażnikami, dlatego traktowali go z pietyzmem, nie unikając apologii i hagiografii. Takie tendencje dominowały zwłaszcza w Galicji.

Działające tam w ramach autonomii dwa uniwersytety - w Krakowie i we Lwowie - były aż do roku 1918 jedynymi polskimi uniwersytetami na ziemiach trzech zaborów, dlatego ówczesne badania historycznoliterackie powinny być oceniane przede wszystkim z perspektywy dorobku tych uczelni (pewien wkład do badań nad romantyzmem wniosło również kilku filologów związanych ze środowiskiem warszawskim). W dwudziestoleciu międzywojennym funkcjonowało, jak wiadomo, już kilka uniwersytetów: w Warszawie ${ }^{2}$, Lublinie, Wilnie, Poznaniu, no i oczywiście w Krakowie i Lwowie, dlatego celowe staje się porównanie osiągnięć lwowskich literaturoznawców z tego okresu z badaniami przedstawicieli tej samej dyscypliny reprezentującymi pozostałe pięć miast. W październiku 1939 r. Uniwersytet Jana Kazimierza przestał być polską uczelnia (8 stycznia $1940 \mathrm{r}$. zmienił nazwę na Uniwersytet Iwana Franki). Sprawiedliwa ocena dokonań lwowskich filologów wymaga uwzględnienia badań uczonych z pozostałych uniwersytetów na terenie II Rzeczypospolitej również do 1939 roku. Porównanie ich w perspektywie synchronicznej pozwala zauważyć to, co wówczas uznawano za nowatorskie i wybitne.

Aby móc wartościować konkretne osiagnięcia badawcze, trzeba zwrócić uwagę na stosunek literaturoznawców do romantyzmu oraz metodologię obowiązująca w zakresie uprawianej dyscypliny. Zagadnienia te już dawno stały się przedmiotem analizy ${ }^{3}$, dlatego w tym miejscu zasygnalizuję jedynie, że pozytywiści, zgodnie z ideologią budowaną na przesłankach racjonalistycznych i empirycznych, odrzucali w badaniach romantyzm rewolucyjny, nie rozumieli fantastyki ani estetycznych dysonansów tamtej literatury. Poszukiwali w niej elementów bardziej umiarkowanych, co uwidoczniło się w szczególnym zainteresowaniu $\mathrm{Pa}$ nem Tadeuszem. To właśnie pozytywiści wysunęli to dzieło na najwyższe

${ }^{2}$ W latach 1870-1915 funkcjonował w Warszawie Cesarski Uniwersytet Warszawski, będący uczelnią prowadzoną na wzór rosyjski i z rosyjskim językiem wykładowym. W 1915 r. został utworzony polskojęzyczny Uniwersytet Warszawski.

${ }^{3}$ Por. Wyka 1951, ss. 186-211; Markiewicz 1987, ss. 703-725. 
miejsce w narodowej literaturze. W 1884 r. ukazała się obszerna książka lwowianina Henryka Biegeleisena „Pan Tadeusz” Mickiewicza, dziesięć lat później Walerego Gostomskiego Arcydrieto poesji polskiej A. Mickiewicza „Pan Tadeusz”. Przez długie lata pozostawały one jedynymi w Polsce monografiami dzieła literackiego.

Badacze pozytywistyczni sporadycznie dokonywali syntezy większych zjawisk historycznoliterackich czy nawet całej epoki, nie zajmowali się (z wyjątkiem wspomnianego Pana Tadeusza) poszczególnymi utworami. Ich zainteresowania przybierały charakter głównie personalny, co skutkowało powstawaniem obszernych, nieraz kilkutomowych monografii Mickiewicza, Słowackiego i Krasińskiego. To one ustaliły na długo karierę „trójcy” wieszczów. Pisarzom mniejszego formatu rzadko poświęcano książki. Monografie wielkich poetów budowane były według schematu ,życie i dzieło”, przy czym życie determinowało dzieło. Zarówno okoliczności powstawania poszczególnych utworów, jak i kreacje bohaterów oraz zawarte w nich problemy interpretowano biograficznie. Nie traktowano tekstu literackiego jako bytu samoistnego. Nie interesowano się walorami artystycznymi dzieła. Stosowano zatem metodę poetocentryczna (życie pisarza w centrum uwagi). Udowadniano, że rozwój literatury determinują czynniki materialne (poglądy Henryka Tomasza Buckle'a) oraz środowisko, w jakim wychował się i tworzył pisarz (filozofia Hipolita Taine'a). Jeżeli literatura stanowi gotowy zestaw wskazówek ideowych, moralnych, obywatelskich, to zadaniem nauki o literaturze jest te wskazówki rozpowszechniać. Subiektywizm badaczy, ich sympatie i antypatie, uwidaczniał się zwłaszcza w monografiach trzech wieszczów.

Wraz z nadejściem Młodej Polski dokonało się przewartościowanie literatury romantycznej. Doceniono jej elementy fantastyczne, spirytualistyczne, podniesiono w badaniach rolę mesjanizmu narodowego, zwrócono się ku Słowackiemu mistycznemu. W mniejszym stopniu eksponowano tendencje moralizatorskie i wychowawcze płynące $z$ książek o pisarzach, ale nadal apologetyzowano trzech wieszczów i w dalszym ciagu badania liczących się literaturoznawców legitymizowały obszerne monografie o Mickiewiczu czy Słowackim, nieco rzadziej o Krasińskim. Ważnym odkryciem była twórczość Cypriana Norwida. Kryteria materialistyczno-środowiskowe, warunkujące rozwój literatury, zaczęły ustępować dopiero po 1900 roku bergsonowskiemu psychologizmowi. Przełomowe znaczenie miały dwie rozprawy lwowianina Juliusza 
Kleinera - „Charakter i przedmiot badań literackich” (1913) oraz „Analiza dzieła" (1914), w których domagał się odtąd od badacza traktowania dzieła jako odrębnego tworu w rzeczywistości ludzkiej, nakazywał też przyjęcie wobec niego postawy estetycznej. W swoich poglądach powoływał się na Wilhelma Diltheya i Henryka Rickerta. Idąc za Henrykiem Bergsonem, nakazywał obcować duchowo z dziełem, aby na początku badania intuicyjnie ująć jego całość. Ustalenia Kleinera stanowiły odejście od poetocentryzmu na rzecz ergocentryzmu, gdzie dzieło jest w centrum uwagi. Koncepcja Kleinera, którą pochwycili inni uczeni, prowadziła do strukturalizmu i stała się podstawą do badań filologicznych w okresie międzywojennym.

W dwudziestoleciu zainteresowanie romantyzmem weszło w fazę kulminacyjną. W powszechnej świadomości odzyskanie niepodległości w 1918 roku kojarzono z zasługami romantycznych wieszczów ${ }^{4}$. Czytelnikami ich dzieł byli znani politycy i wybitni wojskowi. Badacze literatury uznali je za zjawisko wciąż wpływające na świadomość Polaków. Ponieważ jednak romantyczne dążenia i marzenia ziściły się, Polska stała się wolna, należało potraktować tę samą literaturę z nieco innej perspektywy. Obecność tradycji romantycznej była jednak stale odczuwalna w świadomości społecznej: „, [...] i apologeci, i krytycy utwierdzali tradycję ujmowania węzłowych problemów życia polskiego w ścisłym związku z romantyzmem: odwoływali się bowiem do tego samego systemu pojęć i wartości" ${ }^{5}$. Wśród historyków literatury w zasadzie wszyscy wybitni zajmowali się przeważnie romantyzmem, a kilku z nich wyłącznie tą epoka. Wydawało to różnorodne owoce, o czym będzie mowa. Przegląd ważniejszych osiagnięć filologicznych należy jednak rozpocząć od badań prowadzonych pod zaborami.

\section{Monografie Mickiewicza, Słowackiego i Krasińskiego przed rokiem 1918}

Najbardziej reprezentatywne pozycje w dorobku naukowym ówczesnych literaturoznawców stanowiły, jak już wspomniałem, monografie któregoś z trzech wieszczów. Do roku 1914 pod względem ich liczby

4 Janion 1986, s. 121.

${ }^{5}$ Kamiński 1981, s. 354. 
przodował Kraków (ukazało się aż siedem pozycji czterech autorów). Lwowscy filolodzy napisali w tym czasie trzy, pozostałe dwie wyszly spod pióra badaczy literatury niezwiązanych z żadnym uniwersytetem.

Porządkując te publikacje chronologicznie, wypada zacząć od dwutomowej książki Antoniego Małeckiego pt. Juliusz. Stowacki. Jego àycie i drieta w stosunku do wspótczesnej epoki, która wydana w latach 1866-1867 niemal o dwadzieścia lat wyprzedziła kolejne tego typu opracowanie. Małecki, wcześniej profesor filologii klasycznej w Krakowie i Innsbrucku, od 1856 r. do końca życia związał się z Uniwersytetem Lwowskim. Inspiracją do podjęcia kompleksowych studiów nad twórczością autora Kordiana stały się niewydane za jego życia rękopisy, które matka poety, Salomea Słowacka-Bécu, za radą Karola Szajnochy przywiozła z Paryża i zdeponowała właśnie w lwowskim Ossolineum. Małecki jako pierwszy zapoznał się z całą spuścizną wieszcza. Rezultatem, oprócz wspomnianej monografii, były także trzy tomy wydane w 1866 r. jako Pisma pośmiertne Słowackiego. Sama monografia na równi traktuje o życiu i twórczości poety. Zgodnie z ówczesnymi metodami pisania biografii Małecki uzależnił wywody od biografistycznej interpretacji twórczości, co - zdaniem Anity Całek - ,powoduje często utożsamianie rzeczywistości z fikcją literacka, myśli i opinii postaci z wypowiedziami poety" ${ }^{\prime 6}$. Filolog nie rozumiał twórczości okresu mistycznego, ale pozostawił cenne analizy dramatów. Szczególnie wartościowe okazały się dla późniejszych badaczy ustalenia na temat Lilli Wenedy i Anhellego. Książka Antoniego Małeckiego zapoczatkowała typ monografii-rzeki.

Nic zatem dziwnego, że rychło doczekała się ona licznych recenzji i komentarzy. Nie od rzeczy będzie tutaj przypomnienie najsłynniejszej i chyba najbardziej napastliwej polemiki Stanisława Tarnowskiego. Imponujących rozmiarów tekst zatytułowany „Profesora Małeckiego «Juliusz Słowacki»” ukazał się w trzech obszernych częściach w Pržgladzie Polskim już w roku 1867. Cieszący się w tamtym czasie opinią największego w Krakowie autorytetu w sprawach literatury Tarnowski ostro zaatakował sposób ukazania Słowackiego jako człowieka. Oskarżając go, wbrew Małeckiemu, o egocentryzm, izolowanie się od ludzi, adwersarz negował przy okazji romantyzm, czym wpisywał się w retorykę popularną kilka lat po upadku powstania styczniowego. W subiektywnych,

${ }^{6}$ Całek 2012, s. 119. 
emocjonalnych wywodach nie stronił nawet od inwektyw, imputując wieszczowi na przykład zaburzenia psychiczne, czego dowodem miało być konstruowanie przez niego postaci literackich chorych umysłowo (casus Kordiana). Dzisiaj podobny spór można traktować na prawach historycznej ciekawostki albo anegdoty.

Kolejną monografia poświęconą wieszczowi była książka Józefa Tretiaka Mickienvicz, w Wilnie i Kownie. Życie i poesja, którą pisał i wydał jeszcze we Lwowie (1884), gdzie pracował jako nauczyciel szkół gimnazjalnych. $\mathrm{Na}$ jej podstawie uzyskał w Krakowie doktorat w 1885 r., ale jego promotor Stanisław Tarnowski traktował tę rozprawę jako pozycję popularnonaukową ${ }^{7}$. Ponieważ Tretiak po pomyślnym złożeniu kolokwium habilitacyjnego (1890) został zatrudniony w Uniwersytecie Jagiellońskim, z którym był związany aż do emerytury (1911), a książkę doktorską wydał ponownie w znacznie rozszerzonej, dwutomowej wersji w 1898 r. jako Młodość Mickiewricza (1798-1824). Życie i poerja, zostaje ona tutaj zaliczona do dorobku autora jako uczonego krakowskiego. Monografia Tretiaka od początku budziła poważne zastrzeżenia innych badaczy, ponieważ była bardzo subiektywna, tendencyjna. Autor, który był wielkim miłośnikiem wieszcza, bez skrępowania dawał w niej upust swojemu uwielbieniu dla bohatera, kreując z niego apologetyczny wzór wszelkich cnót.

Większą wartość naukową posiada monografia Piotra Chmielowskiego pt. Adam Mickiewicz. Zarys biograficzno-literacki, pozycja dwutomowa wydana w 1886 r. Jej autor, jeden z najbardziej zasłużonych polskich pozytywistów, wychowanek warszawskiej Szkoły Głównej, wybitny publicysta i redaktor kilku czasopism, a zarazem wnikliwy badacz ojczystej literatury, odrzucił w 1882 r. nominację na docenta Imperatorskiego Uniwersytetu Warszawskiego, bo nie chciał wykładać w języku rosyjskim. Monografia Chmielowskiego charakteryzuje się typowo pozytywistyczną metodologia badawcza. Życiorys Mickiewicza rekonstruowany jest ściśle według praw ewolucjonizmu, któremu podlegają nie tylko poczynania poety, ale też otaczające go zjawiska. Zaletą książki są interpretacje dzieł, które pojawiają się obok dokładnych streszczeń. Wadą w opinii Anity Całek okazał się zbyt krótki okres, jaki upłynął między śmiercia poety a napisaniem o nim monografii, To spowodowało, że

${ }^{7}$ Kijas 1966, s. 144. 
o wielu faktach nie można było jeszcze pisać otwarcie, nie udało się też odnaleźć wielu materiałów archiwalnych ${ }^{8}$. Widać skłonność autora do tuszowania wydarzeń niepochlebnych z życia pisarza.

Rok 1892 przyniósł pierwszą monografię poświęconą Zygmuntowi Krasińskiemu autorstwa Stanisława Tarnowskiego (w roku 1912, w setną rocznicę urodzin wieszcza, ukazało się jej drugie wydanie, znacznie rozszerzone, wznowione w 2014 r. z wstępem Andrzeja Waśki). Pokaźnych rozmiarów książka, napisana ze swadą właściwą wytrawnemu mówcy, miała za zadanie przekonać czytelników, że Zygmunt Krasiński, jako przedstawiciel romantyzmu, stanowił najpełniejsze ucieleśnienie tej epoki. Subiektywna narracja Tarnowskiego obejmowała zarówno modelowany wizerunek poety (uczony usprawiedliwiał jego związek z mężatką Joanną Bobrowa, rozgrzeszał go z wieloletniego romansu z Delfiną Potocką, winą obarczając kobietę), jak i specyficzne omówienie twórczości. W niektórych utworach - jak zauważył Henryk Markiewicz - Tarnowski starał się znaleźć uwznioślającą sankcję dla własnych poglądów: „Wystarczała mu ideologia konserwatystów krakowskich, przez pół wieku prawie niezmienna w swoich wytycznych: ortodoksyjna wierność wobec katolicyzmu, poszanowanie „rodziny i własności”, organicznikowska ostrożność, patriotyzm zachowawczy i legalistyczny"'. Charakter prowadzonego wywodu już w czasie ukazania się pierwszego wydania monografii okazywał się anachroniczny i dla wielu badaczy nienaukowy, gdyż - jak to ujął Andrzej Waśko najbardziej uderzającą cechą stylu tej książki jest jej retoryczność: „Tarnowski nie wyjaśnia na sposób pozytywistyczny formy i treści dzieł Krasińskiego czynnikami biograficznymi, oddziaływaniem środowiska czy wpływami literackimi. Nie interesuje go, dlaczego dzieła Krasińskiego sa takie, a nie inne [...]"10. Dla badacza rozstrzygającym kryterium było własne odczucie piękna i prawdy (lub ich braku w tekście). Wyrażanego w taki sposób stanowiska nie uzasadniał. Inną słabą stroną Tarnowskiego jako monografisty była nieznajomość nawet podstaw filozofii, a także brak ,gruntowniejszych studiów filologicznych”, o czym przed laty przypomniał Juliusz Kijas ${ }^{11}$. Książka Tarnowskiego

\footnotetext{
${ }^{8}$ Całek 2012, s. 76.

${ }^{9}$ Markiewicz 1977, s. 20.

10 Waśko 2014, s. XII.

${ }^{11}$ Kijas 1966, s. 118.
} 
szybko straciła aktualność ze względu na nowe badania i kolejne monografie wieszcza.

W roku 1895 ukazała się dwutomowa książka Henryka Biegeleisena zatytułowana Juliusz Stowacki. Autor, związany ze Lwowem od czasu studiów do końca życia, nauczyciel w gimnazjach oraz szkołach innego typu, przez dziesięć lat poszukiwał i opracowywał utwory Słowackiego. W rezultacie wydał w 1894 r. czterotomowe Drieła poety, zaś rok później ogłosił tom 5 i 6 Objaśnień jako osobną pozycję Juliusz Słowacki, która stanowi szczegółowy komentarz do twórczości wieszcza. Biegeleisen podsumował w nim stan badań do 1895 r. Jak zaświadcza Jerzy Starnawski, znacznie wzbogacił rękopiśmienną spuściznę poety wydaną wcześniej przez Antoniego Małeckiego ${ }^{12}$. Nie zajmował się natomiast biografią Słowackiego.

Juliuszowi Słowackiemu poświęcił swoją trzytomową monografię Ferdynand Hoesick. Książka opatrzona tytułem Życie Juliusza Stowackiego na tle wspótcæesnej epoki (1809-1849). Biografia psychologicænna ukazała się w latach 1896-1897. Jej autor, niebędący nauczycielem akademickim, mieszkający przeważnie w Warszawie, mniej w Krakowie, kontynuował rodzinną tradycję księgarzy i wydawców. Badania historycznoliterackie koncentrował przeważnie na romantyzmie. Dzieło o Słowackim tym różni się od pozycji innych autorów, że traktuje wyłącznie o życiu poety (spotykamy w nim jednak cytaty z korespondencji, rzadziej z utworów wieszcza, które mają lepiej ilustrować pewne życiowe sytuacje). Czytelnik znajduje tu rekonstrukcję całego życiorysu - od narodzin do śmierci. Zaletą monografii jest próba obiektywnego ukazania jej bohatera Hoesick rezygnuje z idealizacji, ujawnia słabe strony charakteru poety. Wadą okazuje się niezbyt rzetelny stosunek piszącego do prezentowanych faktów i wykorzystanych źródeł. Jak trafnie zauważyła Anita Całek, autor manipuluje cytatami z tekstów poety, używając ich na poparcie swoich tez albo i hipotez, które często podaje jako fakty. Rzadko też komentuje cytaty. W rezultacie „książka ta stanowi raczej barwną opowieść o życiu Słowackiego"13, co zbliża ją do literatury popularnonaukowej.

Naukową sławę Józefa Kallenbacha ugruntowały dwie monografie o Mickiewiczu i o Krasińskim. Związany z pięcioma uniwersytetami

12 Starnawski 2009, ss. 29-30.

13 Całek, 2012, s. 121. 
(wykładał kolejno we Fryburgu Szwajcarskim, Lwowie, Warszawie, Wilnie i Krakowie) uczony najdłużej pracował we Lwowie (1904-1914 i 1916-1919). Obejmował tam katedrę po zmarłym Piotrze Chmielowskim już jako autor obu prac. W 1897 r. ukazało się dwutomowe dzieło Adam Mickiewicæ. Napisane gładką, potoczystą, prawie literacką polszczyzna przynosiło wiele nieznanych dotąd szczegółów związanych z biografią wieszcza, w tym mnóstwo ciekawostek. Kallenbach, wytrawny archiwista, zawdzięczał je licznym odkrytym przez siebie rękopisom. Książka stała się bardzo poczytna, obiegła ziemie trzech zaborów i doczekała się aż czterech wydań $(1897,1918,1923,1926)$. Na pewien czas stała się podstawowym kompendium wiedzy o Mickiewiczu. Niestety, sądy o jej naukowej wartości były już zdecydowanie mniej pochlebne. Autorowi zarzucano:

przeładowanie biograficznymi szczegółami, skłonność do eksponowania drobiazgu, ciekawostek (co Wilhelm Feldman określił nawet jako «zwyczajne plotkarstwo») - przy jednoczesnym niedoborze interpretacji twórczości, przy powierzchownych uogólnieniach w sądach o utworach poetyckich ${ }^{14}$.

Powierzchowne badania filologiczne przygniatał wszechobecny biografizm, w dodatku opracowany z zastosowaniem przestarzałej metodologii zwanej poetocentryzmem, która prowadziła Kallenbacha do łączenia życia z twórczością, do tworzenia analogii między Mickiewiczem a jego bohaterami literackimi. Najczęściej jednak oskarżano Kallenbacha o idealizację wieszcza. A czynił to, trzeba przyznać, z niesłychaną konsekwencją: rozmyślnie manipulował ogromnym zbiorem faktów, eksponując tylko te wygodne, a pozostałe cenzurując. Kiedy już nie mógł przemilczać wydarzeń bardzo znanych i ważnych, na przykład zaniechania starań Mickiewicza, by się przedostać na teren Królestwa Polskiego w czasie powstania listopadowego, usprawiedliwiał na wszelkie sposoby poetę, posuwając się do fałszowania ówczesnych opinii o nim. W toku obszernej narracji wielokrotnie podkreślał, że Mickiewicz był wyjątkowy pod każdym względem, a w konkluzji nie wahał

${ }^{14}$ Chrostek 2016, s. 64. 
się przekonywać, że był on bodaj najlepszym z ludzi. Hagiografia, pietyzm, ślepe ubóstwienie - każde z tych określeń trafnie charakteryzuje postawę Kallenbacha.

W kolejnej monografii Zygmunt Krasiński. Życie i twórczość lat młodych, wydanej w 1904 r., uczony w zasadzie powtórzył większość wytykanych mu błędów. Stan badań nad życiorysem trzeciego wieszcza znacznie poszerzył o liczne szczegóły dzięki wyzyskaniu ogromnych bloków korespondencji poety zarówno z ojcem, jak i z Henrykiem Reevem (jako dyrektor Biblioteki Ordynacji Krasińskich miał uczony znacznie ułatwiony dostęp do rękopisów). Wzbogaciły one jego portret psychologiczny o nieznane wcześniej cechy. Niestety, również w tym przypadku Kallenbach usprawiedliwiał wszelkie niebudzące aprobaty poczynania poety, rozgrzeszał nawet jego ojca, Wincentego, carskiego generała, z tłumienia powstania listopadowego. Przemyślna manipulacja materiałem dokumentarnym, bezwzględne cenzurowanie faktów oraz subiektywna, wartościująca narracja autora sprawiały, że czytelnik otrzymywał kolejny wyidealizowany portret wieszcza, na tle którego gubiły się niezbyt liczne i powierzchowne omówienia twórczości.

Dwutomowa monografia Józefa Tretiaka z 1904 r. pod tytułem $J u$ liusz Stowacki budziła w środowisku naukowym znacznie silniejsze emocje niż obie ksiażki Józefa Kallenbacha (Piotr Chmielowski i Wilhelm Feldman nazwali ją wprost pamfletem ${ }^{15}$ ). Nic dziwnego. Uczony, który w pierwszej swojej monografii dał się poznać jako bezkrytyczny apologeta Mickiewicza, w drugiej ujawnił niespotykaną w środowisku filologów niechęć do Słowackiego. Subiektywną narrację oparł on na ciagłym porównywaniu Mickiewicza i Słowackiego jako dwóch przeciwieństw. W mocno tendencyjnym wywodzie stale dominuje gloryfikacja Mickiewicza oraz deprecjonowanie Słowackiego. Wszelkie poczynania tego drugiego rozpatrywane są wyłącznie przez pryzmat Mickiewicza - na niekorzyść jego konkurenta. Dla Tretiaka Słowacki nie jest wybitnym ani nawet zdolnym poeta. Monografista co prawda odwołuje się do jego twórczości, część utworów interpretuje, w tym dzieła z okresu mistycznego, co było wówczas rzadkością i stanowi pewną zaletę tej osobliwej książki. Niestety, ocena wszelkich poczynań Słowackiego, jego poglądów, relacji z innymi, wartości jego utworów jest nieuczciwa. Stanowi

15 Por. Aleksandrowska 1970-1983, t. 16, s. 106. 
emanację osobistych uprzedzeń Tretiaka, które ten w sposób kategoryczny stara się narzucić czytelnikom.

W atmosferze wzmożonego zainteresowania osobą i twórczością Słowackiego, zjawiska charakterystycznego dla okresu Młodej Polski, którego kulminacja nastapiła w setną rocznicę urodzin poety (w $1909 \mathrm{r}$. we Lwowie odbył się ogólnopolski Zjazd historycznoliteracki imienia Juliusza Słowackiego), obok rozpraw i artykułów poświęconych poecie ukazuje się w latach 1909-1912 kolejna monografia wieszcza - dwutomowa praca Tadeusza Grabowskiego Juliusz Stowacki. Jego synwoti dzieła na tle wspótczesnej epoki. Autor, związany zawodowo najpierw z Uniwersytetem Jagiellońskim (1909-1919), a później z Uniwersytetem Poznańskim (1919-1939), zastosowal w niej stosunkowo nową metodę badawcza, jaką był wówczas psychologizm. Dzięki temu udało mu się nieco inaczej niż dotąd zinterpretować część twórczości Słowackiego. Zadaniem monografii stała się rekonstrukcja psychologicznego wizerunku wieszcza. Aby temu sprostać, korzystał jednak Grabowski z ustaleń biograficznych już znanych. Wysoko szacując talent i twórczość poety, analizował ją badacz na tle szeroko ukazanej panoramy romantyzmu polskiego i europejskiego, co okazało się zarówno zaletą, jak i wadą tej książki. Doceniał wyzyskanie tak wielu kontekstów Juliusz Kleiner, jednak - jak zauważyła Anita Całek - charakterystyka epoki zdecydowanie dominuje ilością informacji nad głównym bohaterem ${ }^{16}$. Ma to swoje konsekwencje w niedoborze interpretacyjnym niektórych utworów - według Kleinera Grabowski unika drobiazgowej analizy, powierzchownie omawia technikę poetycką i styl ${ }^{17}$. Słabą stroną jego wywodów jest większa skłonność do referowania wcześniejszych ustaleń niż do samodzielnego komentowania.

W roku 1912, w stulecie urodzin poety, ukazała się pierwsza monografia Juliusza Kleinera Zygmunt Krasiński. Džieje myśli. Praca, którą niespełna 26-letni filolog związany z Uniwersytetem Lwowskim napisał zaledwie w 6-7 miesięcy, od początku była nazywana wielka, nie tylko z powodu objętości (ponad 600 stron w dwóch tomach), ale także przełomowego znaczenia w badaniach nad Krasińskim. Kleiner przyjął nową strategię badawczą - odszedł od dominującej wówczas metody

16 Całek 2012, s. 125.

17 Kleiner 1912, ss. 631-632. 
poetocentrycznej, natomiast „osią konstrukcyjną uczynił myśl filozoficzną poety, której ewolucję ukazał na szerokim tle prądów myślowych romantyzmu europejskiego" ${ }^{18}$. W tym celu czytał wszystko to, co Krasiński, w dodatku - jak podaje Zygmunt Matracki - w tej samej kolejności ${ }^{19}$, następnie badał oddziaływanie tych lektur na poetę. Udowodnił, że Krasiński nie stworzył własnego systemu filozoficznego (jak dotąd uważano), lecz był jedynie filozofującym poetą, który wykorzystywał rozmaite idee do rozwiązywania własnych dylematów intelektualnych. Przewartościował też Kleiner wiele wcześniejszych sądów o twórczości wieszcza, dowodząc, że spadek jego formy poetyckiej nastapił po napisaniu Irydiona. Rekonstruując osobowość Krasińskiego, udowodnił, że zna najnowsze osiagnięcia badań psychologicznych (jako pierwszy zastosował ustalenia Wilhelma Diltheya do badań polskiej literatury), dowiódł niezwykłej znajomości filozofii (uczeń Kazimierza Twardowskiego) oraz niespotykanego w tak młodym wieku oczytania w literaturach europejskich. Zaskakiwał błyskotliwością niezliczonych skojarzeń i budowaniem niekończących się analogii, co wskazywało na wielki talent komparatysty. Monografia Kleinera stanowiła w tamtym czasie i w ciągu kilku następnych dziesięcioleci najlepsze i najpełniejsze opracowanie dotyczące Krasińskiego ${ }^{20}$.

\section{Książki, rozprawy, artykuły o polskim romantyzmie - osiągnięcia filologów pod zaborami}

Na dorobek naukowy literaturoznawców składają się, jak wiadomo, nie tylko monografie (choć te pod zaborami i jeszcze w dwudziestoleciu ceniono najwyżej), ale również publikacje o skromniejszych rozmiarach - obszerne rozprawy, mniejsze artykuły i drobne przyczynki. Do 1914 r. pisali je uczeni związani głównie ze Lwowem, Krakowem i Warszawa, kojarzeni zawodowo zarówno z dwoma uniwersytetami, jak i ze szkolnictwem gimnazjalnym albo redakcjami czasopism. Analiza obszernej bibliografii historii literatury wykazuje prymat pozycji dotyczących polskiego romantyzmu, ze szczególnym uprzywilejowaniem

18 Chrostek 2016, s. 110.

19 Matracki 1975, s. 150.

20 Starnawski, Jerzy 1999, s. 9; Starnawski, Jerzy 1997, ss. 154-155; Chrostek, Mariusz 2016, ss. 110-111. 
postaci i twórczości trzech wieszczów, co po krótkim omówieniu monografii wydaje się oczywiste. Zdarzają się jednak wśród nich teksty poświęcone innym pisarzom tej epoki, w tym sporadycznie monografie. Najliczniejsza grupa badająca często lub tylko okazjonalnie romantyzm reprezentuje Lwów. Na uwagę zasługuja poloniści, w większości zatrudnieni w Uniwersytecie Lwowskim: Antoni Małecki, Roman Pilat, Wilhelm Bruchnalski, Juliusz Kleiner, Konstanty Wojciechowski, Wiktor Hahn, Bronisław Gubrynowicz, Eugeniusz Kucharski, Tadeusz Pini, Henryk Biegeleisen, Stefan Vrtel-Wierczyński, Kazimierz Kolbuszewski, Karol Badecki; romaniści Edward Porębowicz, Zygmunt Czerny i Kazimierz Jarecki; germaniści Richard Maria Werner i Emil Petzold; absolwenci różnych fakultetów Jan Kasprowicz i Jan Gwalbert Pawlikowski. Dołącza do nich Józef Kallenbach, którego lwowski dorobek był zdecydowanie najbogatszy, a nawet związany stale z Warszawą Piotr Chmielowski, dla którego ostatni, lwowski, rok życia okazał się wyjątkowo płodny.

W ośrodku krakowskim (Uniwersytet Jagielloński) częściej lub sporadycznie romantyzmem zajmowali się Stanisław Tarnowski, Józef Tretiak, Stanisław Windakiewicz, Tadeusz Grabowski, Marian Zdziechowski oraz Ignacy Chrzanowski. W Warszawie, działając zwykle poza katedrami rosyjskiego uniwersytetu, podobne zainteresowania dokumentowali Aleksander Tyszyński, Bronisław Chlebowski, Piotr Chmielowski, Józef Ujejski, Manfred Kridl, Walery Gostomski. W Wilnie jako uczony dobrze zapowiadał się młody nauczyciel gimnazjalny Stanisław Cywiński, w Lublinie Piotr Bańkowski. Niezwiązani zawodowo ze szkołami, w którymś z wymienionych miast, publikowali Stanisław Szpotański i Ferdynand Hoesick.

Omawianie, czy choćby tylko wyliczanie w porządku chronologicznym bądź tematycznym, wszystkich pozycji bibliograficznych wymienionych uczonych, które dokumentuja postęp w badaniach polskiego romantyzmu, przekracza rozmiary jednego artykułu. Byłoby to zresztą niecelowe ze względu na funkcjonujące już dawno bibliografie spuścizny większości tych osób. Prawie kompletne zestawienie dorobku niektórych przynosi Bibliografia Literatury Polskiej „Nony Korbut”, tomy 13-16 poświęcone epoce pozytywizmu i Młodej Polski pod redakcja Zygmunta Szweykowskiego i Jarosława Maciejewskiego. Część sylwetek nieuwzględnionych w „Nonym Korbucie” (tych, których dorobek wykracza poza rok 1914) rejestruje Stownik wspótczesnych pisaray polskich pod 
redakcją Ewy Korzeniewskiej, w którym ograniczono się do bibliografii w bogatym wyborze. Cenne uzupełnienie stanowi dziesięciotomowy Stownik badaczy literatury polskiej pod redakcja Jerzego Starnawskiego, w którym autorzy haseł pieczołowicie odnotowali wszystkie ważniejsze publikacje każdego bohatera. W przypisie podaję szczegóły dotyczące większości wymienionych badaczy ${ }^{21}$. Obecnie zwrócę uwagę na bardziej istotne ich dokonania.

\subsection{Dorobek lwowskich uczonych}

Nestor lwowskiej polonistyki Antoni Małecki, oprócz wymienionej już dwutomowej monografii poświęconej Słowackiemu, jako pierwszy opublikował wiele rękopisów tego wieszcza w trzytomowej edycji pt. Pisma pośmiertne (1866), ponadto wydał czterotomowy wybór twórczości poety w 1880 r. Jego najwybitniejszy uczeń Roman Pilat, którego badania dały początek tak zwanej lwowskiej szkole filologicznej, należał do współzałożycieli istniejącego do dziś Towarzystwa Literackiego im. Adama Mickiewicza (1886). Za jego profesury powołano do życia czasopismo Pamiętnik Towaraystwa Literackiego im. A. Mickiewicza (1887), znane od 1902 r. jako Pamietnik Literacki. Publikował zwłaszcza o Mickiewiczu, m.in. „Geneza Farysa” (1888), „Głosy publicystyki emigracyjnej o pierwszych wykładach Mickiewicza w Collège de France” (1889), „Nieznana rozprawka Mickiewicza o Karpińskim”

${ }^{21}$ Bibliografia literatury polskiej „Nowy Korbut” rejestruje dorobek: Antoniego Małeckiego [t. 8: Romantyzm, ss. 348-354], Henryka Biegeleisena [t. 13, ss. 239-242], Wilhelma Bruchnalskiego [t. 13, ss. 270-274], Bronisława Chlebowskiego [t. 13, ss. 332-334], Piotra Chmielowskiego [t. 13, ss. 344-353], Bronisława Gubrynowicza [t. 14, ss. 166-169], Ferdynanda Hoesicka [t. 14, ss. 190-198], Józefa Kallenbacha [t. 14, ss. 264-270], Jana Gwalberta Pawlikowskiego [t. 15, ss. 213-215], Stanisława Pilata [t. 15, ss. 241-242], Tadeusza Piniego [t. 15, ss. 246-249], Edwarda Porębowicza [t. 15, ss. 263-266], Stanisława Tarnowskiego [t. 16, ss. 9-16], Józefa Tretiaka [t. 16, ss. 102-105], Stanisława Windakiewicza [t. 16, ss. 176-179], Konstantego Wojciechowskiego [t. 16, ss. 210-212]. Stownike wspótczesnych pisarayy polskich (wydanie trzytomowe z lat 1963-1964) obejmuje sylwetki: Ignacego Chrzanowskiego [t. 1, ss. 350-357], Stanisława Cywińskiego [t. 1, ss. 373-374], Tadeusza Grabowskiego [t. 1, ss. 599-602], Wiktora Hahna [t. 1, ss. 640-647], Juliusza Kleinera [t. 2, ss. 119-126], Kazimierza Kolbuszewskiego [t. 2, ss. 145-146], Manfreda Kridla [t. 2, ss. 240-243], Eugeniusza Kucharskiego [t. 2, ss. 287-289], Stanisława Szpotańskiego [t. 3, ss. 297-298], Józefa Ujejskiego [t. 3, ss. 385-387], Stefana Vrtela-Wierczyńskiego [t. 3, ss. 466-471]. 
(1890). Najważniejsze i najobszerniejsze prace poświęcił Panu Tadeuszowi, np. „Opis «matecznika» w trzech redakcjach” (1890), „Autografy pierwszych trzech ksiag «Pana Tadeusza»” (1891), „Autografy późniejszych ksiąg «Pana Tadeusza»” (1898), „Opis gry Wojskiego w «Panu Tadeuszu» według autografu" (1899).

Następcą Romana Pilata na Katedrze Języka i Literatury Polskiej (w latach 1904-1931) był Wilhelm Bruchnalski. On również najwięcej uwagi poświęcił Mickiewiczowi. Mocno związany z Towarzystwem Literackim im. Adama Mickiewicza przez wiele lat pozostawal jego prezesem (1900-1905 oraz 1918-1934) lub wiceprezesem (1908-1917). O Mickiewiczu publikowal prace od 1889 r. Wśród pierwszych warto wymienić „Reminiscencje w «Panu Tadeuszu» z Homera, Wergiliusza i Tassa” (1889), „Źródła historyczne «Konrada Wallenroda»” (1889), „ «Grażyna». Według autografu znajdującego się w posiadaniu Konstantego hr. Przezdzieckiego” (1889), „Mickiewicz a Moore” (1891). Wysoko ceniona jest rozprawa „Mickiewicz - Niemcewicz. Studium historycznoliterackie. 1. Twórczość Mickiewicza do roku 1824" (wyd. osobne w 1907 roku). Zainteresowania Driadami zaowocowały kolejnymi pozycjami: „O przyczynki do genezy «Dziadów» wileńskich” (1910), „Przyczynek do genezy «Upiora» i drugiej części «Dziadów». Wyimek z większej całości” (1910). Osobna grupę w Mickiewiczowskiej bibliografii Bruchnalskiego stanowia tak zwane galiciana, które dokumentuja związki wieszcza z Galicją oraz recepcję jego utworów na tym terenie, m.in. „Sąd Galicjanina o Mickiewiczu z lat 1822-1824” (1891), „Pierwsze utwory Mickiewicza naśladowane w literaturze galicyjskiej 1822-1830” (1894), „Sonety Mickiewicza w literaturze galicyjskiej w latach 1827-1828” (1898), „Z tradycji galicyjskiej o dziełach Mickiewicza” (1898).

Jeszcze większe zasługi dla tego wieszcza oddał Bruchnalski jako edytor jego dzieł, zwłaszcza jako popularyzator Pana Tadeusza na skalę wcześniej niespotykaną. Znakomicie opracowany tekst, niedrogi znany jako „Pan Tadeusz za 20 halerzy” - drukowała Macierz Polska w latach 1888-1913 w kolejnych, nienotowanych wówczas, nakładach dziesięciotysięcznych - aż przekroczono w sumie 170 tysięcy egzemplarzy. Epos poety rzeczywiście zaczął trafiać pod strzechy. Z dwunastu tomów Drieł Mickiewicza pod redakcją Romana Pilata do 1914 r. Bruchnalski wydał cztery.

Kiedy w 1903 r. utworzono w Uniwersytecie Lwowskim II Katedrę Języka i Literatury Polskiej, powołano na nią z Warszawy Piotra 
Chmielowskiego. O jego zasługach naukowych wypadnie wspomnieć przy okazji środowiska warszawskiego. Warto jednak podkreślić, jak płodny okazał się dla niego ostatni, właśnie lwowski rok życia. Zdażył tam opublikować rozprawy z zakresu romantyzmu: „Młodość ducha i Mickiewicz” (1903), „Album Mickiewicza” (1903), „Kazimierz Brodziński" (1903). Wydał też ze swoim opracowaniem: Lille Wenede, Nie-Boskea komedie, Pana Tadeusza, Tray poemata Słowackiego, O klasycrności i romantycźności Brodzińskiego (1904).

Józef Kallenbach do Lwowa przybył w 1904 r. już jako monografista Mickiewicza i Krasińskiego, jednak to tutaj, dzięki odkryciu archiwum filomatów i udostępnieniu unikatowych rękopisów przez Stanisławę Pietraszkiewiczównę, znacznie pogłębił badania nad Mickiewiczem, zrewidował wiele dotychczasowych tez, co doprowadziło do drugiego, mocno zmienionego i poszerzonego wydania monografii wieszcza (1918). Autorowi Grasiyny poświęcił również liczne artykuły, jak choćby „Filologia Adama Mickiewicza” (1908), „O nieznanych utworach młodzieńczych Adama Mickiewicza («Mieszko», «Pani Aniela», «Darczanka», «Kartofla», «Warcaby»)” (1909), „Archiwum filomatów” (1909), „Lata uniwersyteckie Adama Mickiewicza” (1910), „Nieznane pisma Adama Mickiewicza (1818-1823)” (1910), „Mickiewicz w Kownie. 1. Pierwszy rok szkolny” (1911), „Tradycja domowa w «Panu Tadeuszu»” (1912), „Ród filomatów” (1914). Wydał też siedmiotomowe Pisma Mickiewicza (1911).

Krasińskiemu poświęcił Kallenbach rozprawę „Lata szkolne Zygmunta Krasińskiego. Nowe materiały” (1906), szkic „Do genezy «Przedświtu»" (1914) oraz studium porównawcze „«Anhelli» i «Ostatni»” (1916). Wydał ponadto dwa tomy listów poety do Zygmunta Cieszkowskiego (1912). O Słowackim pisał niewiele, ale jako jeden z pierwszych literaturoznawców zainteresował się Cyprianem Norwidem, wydając w 1908 r. Assuntę. Nieco uwagi poświęcił w lwowskim okresie poetom krajowym, publikując artykuły o Wincentym Polu, Teofilu Lenartowiczu i Edmundzie Wasilewskim. Wypowiadał się również o publicystyce Maurycego Mochnackiego i twórczości Aleksandra Fredry.

Bronisław Gubrynowicz, związany ze Lwowem do 1920 r., znakomitą większość swoich prac napisał właśnie tam. Koncentrował je głównie wokół Mickiewicza i Słowackiego. Do znaczniejszych należy rozprawa „Piast Dantyszek. Karta z twórczości poetyckiej J. Słowackiego” (1893), obszerna recenzja książki Ferdynanda Hoesicka Życie Stowackiego pod 
tytułem ,Juliusz Słowacki w świetle najnowszej krytyki” (1898) oraz referat wygłoszony w jubileuszowym roku 1909 podczas pamiętnego ogólnopolskiego zjazdu historyków literatury we Lwowie pt. „Stan dotychczasowych badań nad Słowackim" (publikowany w 1910 roku). Najważniejszym jednak dokonaniem okazało się zrealizowane na spółkę z Wiktorem Hahnem wydanie Drię Słowackiego w dziesięciu tomach ${ }^{22}$. Gubrynowicz opracował połowę. O Mickiewiczu publikował artykuły w Pamiętniku Towarsystwa Literackiego im. Adama Mickiewicza od początku lat dziewięćdziesiątych XIX w. Z innych poetów romantycznych upodobał sobie Kazimierza Brodzińskiego, któremu poświęcił rozprawę doktorska (1892), gromadzone zaś w kolejnych latach materiały przyniosły plon w postaci wartościowej monografii Kazimierz Brodziński. Życie $i$ dzieła. C₹. ${ }^{23}$ (ukazała się w 1917 r. we Lwowie).

Wiktor Hahn, mieszkający we Lwowie do 1945 r., jeden z najbardziej zasłużonych w Polsce bibliografów historii literatury polskiej, ze szczególną uwagą traktował w swoich badaniach twórczość Słowackiego. Opracował i wydał pięć z dziesięciu tomów jego Drię. Ogłaszał obszerne studia nad geneza Mindowego, Marii Stuart i Lilli Wenedy, opracował Anbellego, Króla-Ducha, Samuela Zborowskiego, Balladynę. Mniejsze teksty pomieścił w dwóch ksiażkach: Sqkice literackie o Juliuszu Stowackim oraz O ṡycin i dziełach Juliusza S towackiego. Duża popularność zyskała rozprawa „O tzw. bluszczowatości Słowackiego”. Odkrywczy charakter miała praca „Cyprian Norwid o Słowackim”. Pod redakcją Hahna ukazał się w 1910 roku Pamietnik. Zjazdu Historycznoliterackiego im. Juliusza Stowackiego we Lwowie. W trudnych latach pierwszej wojny światowej pilnie przygotowywał bibliografię Słowackiego (druk w 1918 r.), swoją wytężona pracą decydująco przyczynił się do kontynuacji Pamiętnika Literackiego od $1919 \mathrm{r}$.

Konstanty Wojciechowski, najlepszy wówczas znawca polskiej powieści (po jego śmierci w 1924 r. to zaszczytne miano przypadnie innemu lwowskiemu wykładowcy Zygmuntowi Szweykowskiemu), wy-

22 Przygotowywaniu monumentalnej edycji dzieł Słowackiego towarzyszyło ustalanie przez Gubrynowicza wariantów tekstu Benionskiego i Króla-Ducha, które ogłaszał w ówczesnych czasopismach nie tylko lwowskich. Przypomina o tym i lokalizuje te przyczynki w czasopismach Jerzy Starnawski (Starnawski 1997a, s. 106).

${ }^{23}$ Książka imponuje materiałem bibliograficznym, ale urywa narrację na 1817 roku, nie uwzględniając licznych późniejszych dokonań pisarza. 
powiadał się również o Mickiewiczu (np. w znakomitej rozprawie, jednej z pierwszych komparatystycznych w Polsce, „Hrabia w «Panu Tadeuszu» a «Don Kichot»" z 1900 r.). Jednak większe zasługi oddał jako edytor jego dzieł - wydał m.in. Grażyne (1902), Džiady wileńskie (1905), Driadón cześćc III (1905).

Najwybitniejszy reprezentant lwowskiej polonistyki, Juliusz Kleiner, w czasach zaborów dał się poznać nie tylko jako autor najlepszej monografii o Krasińskim. Już doktorat uzyskany przez 22-latka (1908) na podstawie Studiów o Stowackim stał się wydarzeniem podziwianym we Lwowie. Obdarzony genialna pamięcią jako student chłonął ossolińskie rękopisy wieszcza i publikował swoje pierwsze rozprawy o trudnych dziełach z okresu mistycznego poety: „Bohaterka «Króla-Ducha»” (1906), „Książę Michał Twerski. Czwarte wcielenie Króla-Ducha" (1906). Wkrótce wzbogacił dorobek o pozycje poświęcone Mickiewiczowi i Krasińskiemu. Rok 1909 okazał się przełomowy w karierze naukowej młodego badacza. W zbiorowej księdze Cieniom Juliusza Stowackiego, której trzy tomy wypełniły teksty lwowskich studentów oraz nauczycieli gimnazjalnych, umieścił pracę „Dzieło filozoficzne Słowackiego (Układ i stosunek fragmentów)”. Na Zjeździe historycznoliterackim im. J. Słowackiego wygłosił referat „Najważniejsze problemy estetyczne w «Królu-Duchu»”. Największe jednak uznanie zyskał dzięki recenzji dziesięciotomowego wydania Drieł Słowackiego pod redakcją Gubrynowicza i Hahna - „Układ i tekst dzieł Słowackiego (O pierwszym krytycznym wydaniu zbiorowym dzieł poety)". Rozprawa licząca 114 stron petitu została uznana za najbardziej wnikliwą pracę $z$ teorii edytorstwa, za dokonanie ważniejsze nawet niż opracowanie twórczości wieszcza w dziesięciu tomach. Nazwano ją arcyrecenzją. Prorocze, jak dowiodły kolejne lata, okazały się słowa wypowiedziane wówczas przez Tadeusza Grabowskiego: „Nie żył już Chmielowski, Pilat, ale żył jeszcze Małecki, nie mówiąc o Bruchnalskim, Kallenbachu. Z takiego środowiska lwowskiego wyrósł krytyk, mający prześcignąć ich wszystkich [...]. Ogrom erudycji dzielił z Brücknerem, ale przewyższał go głębią spostrzeżeń" 24 .

Kolejna rewelacją w dorobku młodego Kleinera (po uzyskaniu w 1912 r. habilitacji na podstawie wymienionej już monografii o Kra-

${ }^{24}$ Juliusz. Kleiner. Ksiega ₹biorowa..., ss. 170-171. 
sińskim) i zarazem przełomowa w Polsce wypowiedzia z zakresu teorii literatury okazała się rozprawa „Charakter i przedmiot badań literackich" (1913), o której wspomniałem przy okazji zastosowania nowej, ergocentrycznej metody badań w literaturoznawstwie. Odtąd literatura miała stanowić odrębną sferę rzeczywistości, dzieło literackie miało być traktowane jako fakt artystyczny niepowtarzalny, nieutożsamiany z biografią autora. Miało się ono stać, jako spisane słowo, przedmiotem badań historyka literatury. W opublikowanej rok później pracy pt. „Z zagadnień metodologii literackiej. Analiza dzieła” Kleiner rozwijał głoszone poglądy, konstruując nową teorię poznania dzieła.

Z grona pozostałych badaczy polskiego romantyzmu, związanych ze Lwowem w czasie zaborów, którzy w dwudziestoleciu międzywojennym zasilą kadrę naukową Uniwersytetu Jana Kazimierza, warto przypomnieć Eugeniusza Kucharskiego, Kazimierza Kolbuszewskiego i Stefana Vrtela-Wierczyńskiego. Kucharski w centrum swoich zainteresowań umieścił Aleksandra Fredrę. Doktoryzował się na podstawie dysertacji Romantyzm w komediach Fredry (druk w 1911 r.). Do roku 1914 publikował pierwsze o nim prace, przygotował i wydał też Śluby panieńskie. Interesował się również Słowackim (rozprawa „Strofy osobiste w «Beniowskim». I. Geneza” oraz artykuł „U źródeł duszy” (o Genezis z Ducha) i Krasińskim (studium „Do genezy «Snu» w I części «Nie-Boskiej» Zygmunta Krasińskiego"). Największe sukcesy jako pierwszy w Polsce fredrolog odniesie Kucharski w dwudziestoleciu międzywojennym. Kazimierz Kolbuszewski, nauczając w gimnazjach, publikował o Słowackim („Czasy barskie w poezji Słowackiego” - 1909, „Ludwika Śniadecka w rzeczywistości i w poezji Słowackiego” - 1909), Krasińskim („Zygmunta Krasińskiego twórczość w stosunku do literatury niemieckiej” - 1912 oraz „Napoleonizm w twórczości Krasińskiego” 1912) i księciu Józefie Poniatowskim („Książę Józef w powieści polskiej" - 1913). Stefan Vrtel-Wierczyński, który doktoryzował się na podstawie rozprawy poświęconej Krasińskiemu („Przyroda w warszawskim okresie twórczości Zygmunta Krasińskiego" - druk w 1912 r.), sięgał również do twórczości Słowackiego („«Rycerz-Lud» Słowackiego" - z 1916 r.). Interesował się piśmiennictwem Wielkiej Emigracji („Do dziejów satyry na Emigracji po r. 1831” - z 1914 r.).

W sprawach polskich pisarzy romantycznych wypowiadal się również z pozycji uczonego Jan Kasprowicz. Ten wybitny młodopolski poeta, autor licznych przekładów z literatur obcych, związany ze Lwowem 
od 1888 roku, dla którego uniwersytet - aby go pozyskać do grona pracowników - utworzył specjalnie Katedrę Historii Literatury Porównawczej (w 1909 r.), dał się poznać jako autor artykułów o Mickiewiczu („Pojęcia społeczno-polityczne Mickiewicza” - 1890, „Pod znakiem Mickiewicza” - 1898 i „Pod pomnikiem Mickiewicza” - 1904), Słowackim („Słowacki i poezja najnowsza” - 1899) i Lenartowiczu („Lirnik mazowiecki” z 1893 r. oraz „Wieś mazowiecka a poezja Lenartowicza” - z 1898 r., a także dysertacja doktorska „Liryka Teofila Lenartowicza" z 1905 r.).

Znaczący wkład w poznanie polskiej literatury romantycznej wnieśli lwowscy filolodzy nowożytni - romaniści i germaniści. W badaniach prowadzonych do roku 1914 na czoło wysuwa się Edward Porębowicz, uczony wszechstronny, wytrawny znawca wielu europejskich języków i literatur wielu narodów, uważany wówczas za najlepszego polskiego romanistę. Wnikliwe rozprawy komparatystyczne poświęcił trzem wieszczom. Z Mickiewiczem wiąże się „Urywek pierwszego brulionu «Pana Tadeusza»” (1893) oraz kilka prac z roku 1898: „Przyczynek do pojęcia «romantyczność» u Mickiewicza”, „Słówko o motywie ballady «Powrót taty»”, „Gdzie jest źródło wiary Mickiewicza w godność prorocza poety?". Słowackiego przypominal trzykrotnie: $\mathrm{w}$ artykule "Jeszcze «Beatrix Cenci»" (1896), publikując na łamach Chimery nieznane fragmenty Króla-Ducha (1901) oraz ogłaszając „Glosę do «Genezis z Ducha»" (1917). Powracał również do Krasińskiego: w rozprawie „Triady Zygmunta Krasińskiego” (1900), w artykule o Nie-Boskiej komedii, Irydionie oraz o Niedokończonym poemacie. Inny romanista Kazimierz Jarecki dokumentował swoje badania w kolejnych artykułach o Słowackim. Otworzyła je duża rozprawa ,Juliusz Słowacki i poemat «W Szwajcarii)” (1901). Wkrótce ukazały się kolejne, między innymi „Do genezy «Mazepy»” (1903), „Kiedy powstał «Wacław» Słowackiego?” (1903), „Słowackiego «Beatrix Cenci»” (1904), „Testament mój” (1909). Publikował też prace o polskim mesjanizmie („Idee historiozoficzne Woronicza a mesjanizm polski” - 1904) i postaci Andrzeja Towiańskiego („Śp. Karol Baykowski i towianizm”-1904). Trzeci romanista Zygmunt Czerny nawiązywał do wielkich polskich romantyków jedynie okazjonalnie, np. w komparatystycznej rozprawie „Krasiński w literaturze francuskiej" (1912).

Wśród germanistów związanych z Uniwersytetem Lwowskim dwaj zasługują na wzmiankę: Richard Maria Werner i Emil Petzold. Obaj 
Mariusz Chrostek

Przełomowe osiągnięcia Iwowskich filologów w badaniach...

interesowali się polskim romantyzmem, ze szczególnym uprzywilejowaniem Mickiewicza, obaj współpracowali z TLiAM. Pod koniec XIX w. Werner ogłosił m.in. artykuły: „Wiersz Uhlanda do Mickiewicza”, „Wspomnienie Alfreda Meissnera o Mickiewiczu” (1887), „Niemiecki nekrolog Mickiewicza” (1887), „Parę uwag o motywie zasadniczym "Alpuhary»" (1898). Na początku XX w. Petzold wzbogacił lwowskie mickiewicziana o kilka pozycji: „Przyczynek do genezy «Romantyczności» Mickiewicza” (1902), ogłoszone w tym samym roku „Motywy Mickiewiczowskie” (1902), ważną rozprawę „O «Czatach» Mickiewicza" (1905), ponadto komparatystyczne studium polsko-niemieckie: „Reminiscencje z Tiecka w «Dziadach»” (1906), a także „Balladę Mickiewicza a Goethego” (1910). Ta ostatnia należy do najlepszych w dorobku autora.

Omawiając zasługi lwowskiego środowiska naukowego w badaniach polskiego romantyzmu, nie sposób pominać kilku postaci niezwiązanych z uniwersyteckimi katedrami. Głośne w epoce Młodej Polski stały się studia Jana Gwalberta Pawlikowskiego nad twórczością mistyczną Słowackiego. Jako jeden z pierwszych eksplorował tę część dorobku poety. Każda kolejna publikacja miała pionierski charakter: „O mistycyzmie Słowackiego” (1899), „Ze studiów nad «Królem-Duchem». Popiel” (1904), „Z komentarzy do «Króla-Ducha». Sen anhelliczny Mieczysława o dwunastu aniołach" (1906), wreszcie ukoronowanie tych dociekań - słynna książka „Studiów nad «Królem-Duchem» cz. I. Mistyka Słowackiego" (1909). W wolnej Polsce filolog kontynuował te badania.

Henryk Biegeleisen, nauczyciel gimnazjalny, przede wszystkim zaś niestrudzony badacz biografii i twórczości największych romantycznych poetów, pozostawił imponujący dorobek zarówno naukowy, jak i edytorski. Poza wspomniana już pierwszą w Polsce monografią dzieła literackiego, którą była ponad 400-stronicowa książka habilitacyjna „ „Pan Tadeusz» Adama Mickiewicza. Studium estetyczno-literackie” (1884), poza 6-tomową edycją Dzieł Słowackiego (z ogromnym, dwutomowym aparatem krytycznym), pozostawił szereg obszernych rozpraw i mniejszych artykułów o Mickiewiczu (m.in. „Atak Mickiewicza na obóz klasyków” - 1885, „Adam Mickiewicz jako rewolucjonista” - 1887, „Tło ludowe ballady «Ucieczka» A. Mickiewicza” - 1885, „Motywy ludowe w balladzie Mickiewicza «Lilie»” - 1891), Słowackim (np. „Wpływ rodziny na Słowackiego” - 1885, „Wrażenia z podróży J. Słowackiego”1891, „Juliusz Słowacki i Maria Wodzińska” - 1893, „Kobiety w życiu 
Słowackiego” - 1895, „Nieznany dziennik podróży do Ziemi Świętej J. Słowackiego” - 1906) i Krasińskim (m.in. „Komedia Nieboska w świetle współczesnej krytyki” - 1896, „Myśl społeczna «Irydiona»” 1898, „Do genezy Nieboskiej” - 1907). Sporo miejsca w dorobku uczonego zajmują również inni poeci. Teofilowi Lenartowiczowi poświęcił Biegeleisen monografię, co było rzadkością w odniesieniu do pisarza innego niż któryś z wieszczów. Książka „Lirnik mazowiecki. Jego życie i dzieło w świetle nieznanej korespondencji poety" (1913) stanowi pierwsze tego typu opracowanie poświęcone Lenartowiczowi. Odkrywał tajniki spuścizny Fredry (,Z nieznanego pamiętnika A. Fredry” 1892), a także Pola („Nieznany pamiętnik Wincentego Pola” z 1901 r. oraz kilka późniejszych prac). Nie pomijał bardziej ogólnych zjawisk epoki („Echa walki romantyków z klasykami” - 1885). Jako pierwszy opublikował dziennik Słowackiego z ostatnich lat jego życia (1883). Jest twórca 4-tomowej edycji Dzieł Mickiewicza (1893), 5-tomowej edycji Diieł Fredry (1897) oraz monumentalnych, również 5-tomowych „Ilustrowanych dziejów literatury polskiej” (1898-1906), w których oświecenie i romantyzm wypełniaja tom ostatni.

Tadeusz Pini, nauczyciel w szkołach średnich, redaktor kilku cenionych serii wydawniczych, dał się poznać zarówno jako historyk literatury jak i zasłużony edytor. Zainteresowania polskim romantyzmem rozdzielał bardziej sprawiedliwie między jego przedstawicieli, o czym świadczą tytuły ważniejszych publikacji. Koncentrował się oczywiście na najwybitniejszych: „Zygmunta Krasińskiego tak zwany «Niedokończony poemat»” (1895), „Studium nad genezą «Irydiona» Zygmunta Krasińskiego” (1899), „Mickiewicz jako wydawca poezji Garczyńskiego” (1898). Nie pomijał jednak poetów mniejszego formatu: „Stefan Garczyński. Szkic biograficzno-literacki” (1898), „Garczyński i Krasiński. Szkic literacki” (1899), „Władysław Syrokomla i jego utwory” (1901). Najbardziej znacząca pozycję w naukowym dorobku Piniego stanowi monografia o Krasińskim, która ze względu na datę wydania (1928) zostanie omówiona nieco dalej. Jako edytor twórczości romantyków zdziałał Pini chyba więcej niż inni lwowscy filolodzy - zarówno we Lwowie pod zaborami, jak i w wolnym polskim mieście. Do ważniejszych osiagnięć z tego pierwszego okresu wypadnie zaliczyć ośmiotomowe Pisma Zygmunta Krasińskiego (Lwów 1904), dwutomowy Wybór pism Mieczysława Romanowskiego (Lwów 1904-1905), dwutomowe Drieła Juliusza Słowackiego (Lwów 1909), dwunastotomowe Drieła 
wsaystkie Adama Mickiewicza (Lwów 1911-1913), ponadto Mickiewicza Diqeła zbiorowe (1912) oraz Wybór pism (1915), Krasińskiego Wybór pism (1915), Słowackiego Wybór pism (1915) oraz wiele edycji pojedynczych utworów trzech wieszczów.

Polonista Karol Badecki, którymi mimo habilitacji w UJK nie związał się z żadną uczelnią, autor cenionych prac z literatury staropolskiej, zasłużony historyk Lwowa, czasami również sięgał do twórczości romantyków, o czym świadczy rozprawa „Aleksander Fredro a Zygmunt Krasiński” (1910).

\subsection{Dokonania literaturoznawców $\mathrm{z}$ Krakowa, Warszawy $\mathrm{i}$ innych miast}

W ośrodku krakowskim zainteresowania literaturą romantyczną dokumentowali autorzy monografii o Mickiewiczu, Słowackim lub Krasińskim. Stanisław Tarnowski do końca XIX w. opublikował m.in. artykuły „Komedie Aleksandra Fredry” (1876) i „Henryk Rzewuski” (1887). Większość prac pomieścił w czterech tomach Studiów do historii literatury polskiej. Wiek. XIX. Rozprawy i sprawozdania (1895-1896) (romantyzm obejmuje jednak dwa tomy, pozostałe dotyczą literatury staropolskiej). Wybrane rozdziały traktują o utworach Mickiewicza, Słowackiego, Fredry, o poetach Stefanie Garczyńskim, Lucjanie Siemieńskim i Teofilu Lenartowiczu. Po roku 1900 wrócił jeszcze Tarnowski do dwóch wieszczów (w rozprawie z 1903 r. „Czyściec Słowackiego” oraz w artykule z 1905 r. „Mickiewicz Adam. «Pan Tadeusz». Uwagi”). Żywa, zajmujaca narracja, kwiecisty język zapewniały tym pracom poczytność, jednak subiektywne kryteria wartościowania, zależne od gustu i estetycznego przeżycia autora, przy braku filologicznych metod analizy tekstu, sprawiały, że szybko traciły one wartość naukową.

Józef Tretiak, który w monografiach dał się poznać jako stronniczy apologeta Mickiewicza i pogromca Słowackiego, należy do tych nielicznych autorów, którzy równie obszerna pracę poświęcili jednemu z pomniejszych poetów romantycznych. Dwutomowa monografia Bobdan Zaleski (1911-1914) stanowi pierwsze takie opracowanie życia i dorobku tego poety. W artykułach z upodobaniem zajmował się Mickiewiczem - kilka publikowanych w czasopismach w różnych latach ukazało się ponownie w zbiorze Szkice literackie. Seria I (1896). Komparatystyczny charakter maja pozycje pomieszczone w książce Mickiewiczi i Pus₹łkin. 
Studia i sqkice (1906). Do innych pisarzy tej epoki nawiązywał sporadycznie - do wyjątków trzeba zaliczyć większe omówienie „Kornel Ujejski i jego poezja" (1893).

Filologiczne zainteresowania romantyzmem bliskie były Stanisławowi Windakiewiczowi, który przed rokiem 1910 przedłożył je ponad dotychczasową literaturę staropolską. W badaniach literackich preferował wówczas metodę komparatystyczna, krytykował pozytywistyczny materializm i ewolucjonizm, deklarując się jako zwolennik psychologizmu ${ }^{25}$. Dla Tarnowskiego zbyt nowoczesny jako wykładowca uniwersytecki, uprawiał jednak Windakiewicz metodologię typową dla schyłku Młodej Polski. Monografii wieszcza wprawdzie nie napisał, ale do roku 1918 wydał aż trzy książki przynoszące wiele wartościowych ustaleń na temat ich dorobku: Badania \{́ródtowe nad twórczościa Stowackiego (1910), Walter Scott i Lord Byron w odniesieniu do polskiej poezji romantycznej (1914) oraz Prolegomena do „Pana Tadeusza” (1918). Szczególnie ta ostatnia wywołała krytykę innych literaturoznawców, którzy dostrzegali w niej, podobnie jak we wcześniejszej, wadliwe założenia metody komparatystycznej, polegające na doszukiwaniu się w utworach nadmiernych wpływów z innych literatur, innych pisarzy, co obarczało balastem zapożyczeń nawet arcydzieła.

Związany z Uniwersytetem Jagiellońskim do 1919 r. Tadeusz Grabowski oprócz monografii o Słowackim trzy prace poświęcił Krasińskiemu w jubileuszowym roku poety, spośród których rozmiarami wyróżnia się broszura Zygmunt Krasiński. Jego ṡywot $i$ dzৃieła na tle wspótczesnej epoki (1912). Pozostając pod nazbyt dużym wpływem swojego mistrza Stanisława Tarnowskiego, ignorował badania genetyczno-historyczne w literaturze, skupiając się na zawartej w niej ideologii. Jego narracja skażona była ,apodyktycznym subiektywizmem ocen”26. Nieznajomość metodologii czy może nieumiejętność wykorzystania jej zdobyczy maskował stosowanym w każdej rozprawie eklektyzmem ${ }^{27}$. Józef Ujejski również łączył swoje losy z Krakowem do 1919 r., gdzie doktoryzował się na podstawie rozprawy Juliusza Stowackiego „Kordian” (1907, druk w 1909) i habilitował (1917). Ulubioną epoką filologa stał się romantyzm, w obrębie którego koncentrował się zwłaszcza na ideach,

\footnotetext{
${ }^{25}$ Kijas 1966, s. 149.

${ }^{26}$ Maciejewski 1992, s. 57.

${ }^{27}$ Ibidem, s. 57.
} 
prądach umysłowych, duchowym obliczu tego okresu. Do ważniejszych rozpraw z tego czasu należy „Ogólny rzut oka na prądy religijno-społeczne wśród emigracji po r. 1831” (1915) i „Główne idee w «Anhellim» Słowackiego" (1916). Interpretacja Anhellego, zawierająca krytyczną ocenę ukazanych tam Polaków na zesłaniu i wykładnię sensu ich cierpienia, pozostaje aktualna do dziś. Ignacy Chrzanowski, który w 1910 r. przybył z Warszawy do Krakowa na katedrę uniwersytecka, szczególnym zamiłowaniem darzył literaturę Pierwszej Rzeczypospolitej. Romantyzmu dotyczy kilka pozycji, m.in. rozprawa „O komediach Aleksandra Fredry” (1917) oraz przedruki wcześniejszych artykułów w zbiorze $Z$ epoki romantyzmu. Studia i szkeice (1918), głównie o Mickiewiczu. Niedługą listę uczonych związanych z Krakowem zamyka Marian Zdziechowski, doktor filozofii i znawca literatury powszechnej nowożytnej. Z romantyzmu polskiego interesował go głównie mesjanizm, któremu poświęcił tom Wirja Krasińskiego. Ze studión nad literatura i filozofiapolska (1912) oraz komparatystyczną rozprawę „Mesjanizm polski a mesjanizm włoski” (1916).

W Warszawie mimo braku polskiego uniwersytetu działało do roku 1918 kilku zasłużonych literaturoznawców. Jako pierwszy badania nad romantyzmem podjął Aleksander Tyszyński zaledwie kilka lat po zakończeniu tej epoki. Powołany w 1866 r. na Katedrę Historii Literatury Polskiej w Szkole Głównej dokonał wstępnej oceny poezji romantycznej w rozprawie „Dwie Świtezianki, czyli rzut oka na ostatni okres poezji polskiej” (1871). W tomie Wizerunki polskie. Zbiór sækicón literackich (1875) pisał o poezji Władysława Syrokomli i Wincentego Pola. Syntetyczny charakter ma praca ,Józef Ignacy Kraszewski i jego powieści historyczne" (1877). W drobniejszych publikacjach zajmował się poezja Słowackiego i Krasińskiego.

Absolwentem Szkoły Głównej był Bronisław Chlebowski. Nauczyciel warszawskich gimnazjów i redaktor wydawnictwa Wiek XIX. Sto lat myśli polskiej część swoich rozpraw dotyczących Mickiewicza, Słowackiego i Krasińskiego publikowal w kolejnych tomach tej serii: Adam Mickiewicz (1907), Stowacki Juliusz (1908), Krasinski Zygmunt (1909), Kraszenski Józef Ignacy (1913). Warte wymienienia są także artykuły „Idea, układ i artyzm «Dziadów» kowieńskich i «Fragmentów» pośmiertnych" (1907), „Słowacki i Szekspir” (1908) oraz „Jak powstawały «Dziady» kowieńskie" (1911).

Szczególną przysługę późniejszym historykom literatury oddał Piotr Chmielowski. Monografista Mickiewicza, jeden z dwóch - obok 
Aleksandra Świętochowskiego - najwybitniejszych publicystów pozytywistycznych, niezwykle pracowicie przewertował ogromne archiwalia i opracował bardzo dokładnie bazę źródłową literatury XIX w. Do zasobów polskiego romantyzmu sięgał wielokrotnie, chociaż, zdaniem Janiny Kulczyckiej-Saloni, był on raczej historykiem idei, a nie samej literatury ${ }^{28}$. Pierwszym dojrzałym owocem tych zainteresowań, wydanym w 1873 r., była poczytna książka Kobiety Mickiewicza, Stowackiego $i$ Krasińskiego. Studium literackie (do końca XIX w. miała aż cztery wydania). Oprócz obszernych prac o Mickiewiczu (m.in. „Odczyty Mickiewicza w Lozannie” - 1884, ponad 180-stronicowe „Estetyczno-krytyczne poglądy Adama Mickiewicza" - 1888-1898 czy ponad 100-stronicowe „Filozoficzne poglądy Mickiewicza” - 1897-1898) publikował artykuły traktujące o romantycznych powieściopisarzach, gdyż preferował w literaturze racjonalizm i zdrowy intelekt (np. „Zygmunt Kaczkowski. Jego życie i działalność literacka” - 1876, „Józef Korzeniowski. Charakterystyka pisarza i dzieł jego" - 1890-1892). Korzeniowskiemu i Kraszewskiemu poświęcił też dwie książki Nasi powieściopisaræe. Zarysy literackie $(1887,1895)$. Osobnej niedużej książeczki doczekał się również poeta Kazimierz Brodziński (1903). Syntetycznego ujęcia romantyzmu dokonał w sześciotomowej Historii literatury polskiej, ma ono jednak charakter popularnonaukowy. W ocenianiu pisarzy $\mathrm{i}$ ich dorobku Chmielowski nigdy nie był stronniczy. Nawet trzeciorzędnych literatów starał się traktować z szacunkiem. Nikogo nie ośmieszał ani zanadto nie chwalił, mimo to nieraz zarzucano mu, że przecenia beztalencia.

Romantyczne inklinacje zdradzał od początku naukowej kariery absolwent lwowskiej polonistyki i kolega Kleinera z czasów studenckich Manfred Kridl. Po uzyskaniu doktoratu jeszcze we Lwowie na podstawie pracy Mickiewricz i Lamennais. Studium porównawcze (1909) i dodatkowych studiach za granicą przeniósł się do Warszawy. W czasach zaborów pisał przede wszystkim o Mickiewiczu oraz relacjach między Mickiewiczem a Słowackim: „Walka Słowackiego z Mickiewiczem. (Próba uzasadnienia końcowego ustępu V pieśni «Beniowskiego»)” (1909), „Z dziejów stosunku Słowackiego do Mickiewicza. Streszczenie” (1910), „Mickiewicz w świetle nieznanych pism” (1910) oraz „Ustęp z «Kursu literatury polskiej w. XIX» [o Mickiewiczu]” (1911). Walery Gostomski, który

${ }^{28}$ Kulczycka-Saloni 1964, s. 222. 
mieszkał w Warszawie od 1895 r., kojarzony jest z romantyzmem dzięki wymienionej wcześniej monografii Arcydzieło poez̧ïpolskiej. A. Mickiewicza „Pan Tadeusz”. Studium krytyczne (1894).

Spośród historyków literatury działających poza Lwowem, Krakowem i Warszawą na wyróżnienie niewątpliwie zasługuje związany z Wilnem Stanisław Cywiński. Ucząc w gimnazjach, ujawnił się jako jeden z pierwszych badaczy twórczości Norwida: w pracy „O Cyprianie Norwidzie słów kilka" (1909), w recenzji Pism zebranych wydanych przez Miriama [Zenona Przesmyckiego] (rec. z 1912) oraz w artykule „Ewolucja w literaturze" (1914), gdzie określił stopień wpływu trzech wieszczów na poetę, a także jego oryginalność w literaturze europejskiej. Nieco filozoficzny charakter zachowała obszerna rozprawa „Romantyzm a mesjanizm" (1914). Kojarzony w dwudziestoleciu międzywojennym z Lublinem (KUL) Piotr Bańkowski, polonista i historyk, jeszcze jako student opublikował dwa interesujące artykuły dotyczące romantyzmu: „Adam Mickiewicz i romantycy warszawscy. (Pierwsze płody poezji romantycznej w świetle krytyki Mickiewicza)” (1909) i „Norwidowe poglądy na sztukę" (1910), ponadto doktoryzował się, przedstawiając rozprawę Maurycy Mochnacki jako teoretyk i krytyk romantyzmu polskiego (1913). Zygmunt Lubicz-Zaleski, wykładowca paryskich uczelni, a od 1929 r. Uniwersytetu Warszawskiego, pierwszą ważniejszą pracę zatytułowal „Kobieta i kobiecość w poezji J. Słowackiego” (1910). Pisał też o Krasińskim (broszura Zygmunt Krasiński. O dziełach $i$ syciu poety w setna rocznice urodzin z 1912 r.), a także o kontaktach Mickiewicza z Edgarem Quinetem (Stosunki A. Mickiewicza z. E. Quinetem wg nieznanych swriadectw i listón - 1913). W 1914 r. ogłosił listy Mickiewicza i Quineta. Ignacy Matuszewski nie był historykiem literatury, lecz jej krytykiem, ale nie sposób pominać jego głośnej pracy Stowacki i nowa sqtuka (1902), jednej z pierwszych, która popularyzowała badania okresu mistycznego w twórczości poety.

Niezwiązani zawodowo z uniwersytetami dwaj monografiści romantycznych wieszczów, Stanisław Szpotański i Ferdynand Hoesick, również mniejszymi publikacjami pomnażali badania nad tą epoka. Szpotański do 1918 r. zdążył wydać monografię poświęconą krytykowi literackiemu i pisarzowi Maurycemu Mochnackiemu (Maurycy Mochnacki - 1910). Opracowywał też ze Stanisławą Pietraszkiewiczówną rękopiśmienną spuściznę po filomatach, która ukazała się jako część 2. Archiwum filomatów już w wolnej Polsce (1920-1921). Hoesick koncentrował się na 
szczegółach z biografii Słowackiego i Krasińskiego, rzadziej Mickiewicza, a spoza pisarzy Chopina, chociaż pierwsza jego duża rozprawa (80 stron) „«Anhelli» i «Trzy poematy». Przyczynki do dziejów twórczości Juliusza Słowackiego" z 1895 r. traktuje o literaturze. W książce O Stowackim, Krasinsskim i Mickiewiczu. Studia historycznoliterackie (1895) pomieścił artykuły zarówno o dziełach jak i życiu tych poetów. Najważniejszym dokonaniem filologa była omówiona już trzytomowa biografia o Słowackim. O Chopinie pisał w roku 1899 (Fryderyk Chopin. Zarys biograficæny - 1899). Od 1896 r. ogłaszał w odcinkach cykl zatytułowany Miłośc w syciu Zygmunta Krasinskiego (wydany osobno w 1909 r.). Z innych pozycji godne uwagi sa dwie obszerne prace biograficzne o charakterze popularnonaukowym: Nad woda wielka $i$ caysta. $Z$ siycia poetów nad Lemanem (1902-1903) oraz Nad jeziora wtoskim brzegiem. Wspomnienie ₹. sycia Zjgmunta Krasińskiego (1902-1903), a także spore studium „«Siła fatalna» poezji Słowackiego. Przyczynek do sławy pośmiertnej poety” (1918), która zamyka dokonania uczonego w latach zaborów.

\section{W dwudziestoleciu międzywojennym}

\subsection{Monografie trzech wieszczów - prymat Juliusza Kleinera}

W dwudziestoleciu międzywojennym zainteresowanie polskim romantyzmem odegrało jeszcze większą rolę w badaniach historyków literatury. Nadal dawano pierwszeństwo wieszczom, przy czym nastapił wyraźny spadek popularności Zygmunta Krasińskiego na rzecz odkrywanego ciagle Cypriana Norwida. Monografii poświęconych wielkiej trójce poetów powstało mniej, ale za to były wśród nich dwie najwybitniejsze. Autorzy starali się unikać nadmiernego subiektywizmu, apologetyzowania swoich bohaterów, chociaż nie zawsze im się to udawało. Podwaliny nowoczesnej koncepcji romantyzmu położył Juliusz Kleiner przed rokiem 1914. Wymienia się obok niego wprawdzie jeszcze Ignacego Chrzanowskiego i germanistę Zygmunta Lempickiego, ale jak zaznaczył Kazimierz Wyka - Chrzanowski w swoim odczycie Charakterystyka $i$ wartości syciowe romantyzmu, wygłoszonym w 1916 r. we Lwowie, wyraźnie pod wpływem Kleinera opracował własna charakterystykę epoki ${ }^{29}$. Natomiast Lempicki w książce Renesans. Oświecenie.

${ }^{29}$ Wyka 1951, s. 192; por. Chrzanowski 1917, ss. 1-69. 
Romantyzm (1923) ograniczył swoje rozważania do romantyczności niemieckiej, a nawet zawęził je do twórczości jedynie Novalisa ${ }^{30}$. W Kleinerowskim ujęciu romantyzmu najważniejszy staje się stosunek jednostki do otaczającego świata, co nieuchronnie prowadzi do konfliktu, ponieważ owa jednostka przerasta otoczenie stopniem wrażliwości, bogactwem życia wewnętrznego, reprezentuje wartości wyższe. Niezgodę na zastaną rzeczywistość $\mathrm{i}$ w rezultacie bunt, który leży u podstaw romantyzmu, manifestuje ona ucieczka, która może przybierać różne kierunki: do krajów Orientu, w historię (do średniowiecza), w fantastykę, w ludowość czy w kontemplacje przyrody. Na takich założeniach Kleiner budował monografie Słowackiego i Mickiewicza (na kolizji kultury i życia - by posłużyć się sformułowaniem Zygmunta Matrackiego ${ }^{31}$ ), z takiej podstawy metodologicznej czerpali w dwudziestoleciu inni liczący się badacze tej epoki.

Monografia Juliusz Stowacki. Dzieje twórczości powstawała w latach 1912-1927. W roku 1919 ukazały się dwa pierwsze tomy, w 1923 wyszedł we Lwowie tom trzeci, natomiast w 1927 najobszerniejszy czwarty (w dwóch dużych woluminach) dotyczący okresu mistycznego w twórczości poety. Największa w Polsce monografia poświęcona jednemu pisarzowi (łącznie 2250 stron) była pisana głównie we Lwowie, który ze względu na paryskie rękopisy Słowackiego zdeponowane w Ossolineum okazał się, zgodnie $z$ określeniem Jerzego Starnawskiego, prawdziwą mekką dla wszystkich badających spuściznę wieszcza.

Jak wskazuje podtytuł Džeje twórczości, osią konstrukcyjna, wokół której Kleiner prowadził narrację, były dzieła literackie. Filolog wyzyskał je w stopniu większym niż w poprzedniej monografii o Krasińskim: na ich podstawie śledził ewolucję możliwości poetyckich autora Kordiana. Odchodził tym samym od metody poetocentrycznej, dominującej ciagle u innych monografistów, na rzecz ergocentryzmu. W rozważaniach o Słowackim widoczne są jeszcze pozostałości młodopolskiego psychologizmu, ale także nowe wpływy popularnych w dwudziestoleciu poglądów Zygmunta Freuda oraz prowadzonych na bazie freudyzmu polskich badań Stefana Baleya (działającego właśnie we Lwowie), który pragnął poznać zakamarki psychiki wieszcza (chodzi o dwa artykuły:

\footnotetext{
30 Janion 1965, ss. 369-370.

31 Matracki 1975, s. 146.
} 
„Psychologiczne uwagi o genezie poematu Słowackiego «W Szwajcarii»” z 1921 r. oraz „Psychoanaliza jednej pomyłki Słowackiego” z 1924 r.).

Monografia Kleinera o Słowackim okazała się rewelacją w ówczesnych badaniach literaturoznawczych. Konrad Górski nazwał ją największym dziełem w polskiej nauce o literaturze.

Ujawniła ona gruntowna znajomość tekstów poety i wszystkich wcześniejszych, nawet najdrobniejszych opracowań. [...] Podążając tropem kolejnych utworów Słowackiego, czytelnik odkrywał nieprzebrane bogactwo romantyzmu polskiego i europejskiego - dzięki znakomitym ujęciom komparatystycznym i częstym skojarzeniom z dziełami malarstwa, rzeźby, architektury, a zwłaszcza muzyki. Dostrzeganie literatury jako syntezy sztuk stanowiło w tamtym czasie o nowatorskich i oryginalnych metodach badawczych. Odbiorców takiej lektury urzekał ponadto piękny, kunsztowny, z lekka archaizowany, literacki styl Kleinera ${ }^{32}$.

Ogromne, niespotykane u innych badaczy, oczytanie w literaturze europejskiej, pieczołowicie wyzyskane w rozległych studiach komparatystycznych, zawdzięczał Kleiner zagranicznym urlopom naukowym: pierwszy (1909-1910) spędził w bibliotekach Berlina i Paryża, kolejny (1823-1824) we Francji i we Włoszech. Rękopisy uczonego, odnalezione w dwóch jego teczkach osobowych zdeponowanych w lwowskim archiwum, oświetlaja powody tych wyjazdów:

O ile by ktoś dziwił się, iż poloniście nie wystarczają biblioteki polskie, to dla wyjaśnienia zaznaczam, [...] że ani monografii o dziejach myśli Krasińskiego, ani monografii o Słowackim nie byłbym mógł napisać bez materiałów, których dostarczył mi przed dwunastu laty pobyt w Paryżu i w Niemczech. Łatwo się przekonać, że znacznej ilości dzieł, przytoczonych w książce o Krasińskim, nie posiada żadna z bibliotek polskich [...]. Szczególnie zbadanie dokładne atmosfery umysłowej paryskiej z lat 1840-1849, nieodzowne dla tomu IV monografii o Słowackim, wymaga wyjazdu do Paryża, którego biblioteki rozporządzaja całą ówczesną literaturą bieżącą ${ }^{33}$.

32 Chrostek 2016, s. 115.

33 Dierżawnyj Archiw Lwiwskoji Obłasti (DALO) fond (dalej: f.) 26, opis (dalej: op.) 5, sprawa (dalej: spr.) 848: druga teczka osobowa Juliusza Kleinera, karta (dalej: k.) 104. 
Wśród wielu entuzjastycznych recenzji pojawiły się również nieliczne i łagodne głosy krytyczne. Bronisław Gubrynowicz wskazał brak polemik podejmowanych z niektórymi cytowanymi poglądami poprzedników. Innym zarzutem był pewien brak proporcji, polegający na uprzywilejowaniu analizy dramatów i poematów, przy drugorzędnym traktowaniu wierszy. Pomimo tych zastrzeżeń monografia Kleinera była uważana jeszcze przez wiele lat po jej ukazaniu się za najważniejsze źródło wiedzy o życiu i twórczości Słowackiego. Współcześnie często bywa cytowana i stanowi ciagle punkt odniesienia dla kolejnych badaczy tego pisarza.

W 1927 r., chociaż jeszcze nie obeschło pióro po monografii o Słowackim, Kleiner zaczął pracować nad Mickiewiczem. Tom I Mickiewič: Drieje Gustawa ukazał się w setną rocznicę wydania Pana Tadeusz̨a w 1934 roku. Autor z benedyktyńska pracowitością przedarł się przez ogromną bibliografię wieszcza, wyzyskując wszelkie ustalenia poprzedników. Do monografii włączył wszystkie teksty poety, nawet bardzo drobne i takie, o których wcześniej nie wiedziano, że istnieją. Drobiazgowo też i sprawiedliwie (inaczej niż w Stowackim) omawiał zarówno dramaty, jak i nieduże utwory liryczne. W centrum zainteresowania znalazły się dzieła literackie. Biografia stanowiła konieczne tło poznawcze (związek poezji z życiem), na którym śledzimy nie tylko twórczość, ale też wszelkie inne formy aktywności Mickiewicza. Opasły tom I, w którym uczony doprowadził wieszcza do pobytu w Rosji (już po Sonetach krymskich), zapowiadał dzieło będące summą dotychczasowej wiedzy o poecie.

Znaczenie monografii o Mickiewiczu trudno doceniać na przykładzie tylko I tomu, gdyż dopiero całość daje wgląd w Kleinerowską koncepcje postaci pierwszego wieszcza. Tom II Mickiewicæ. Drieje Konrada ukazał się dopiero po wojnie w Lublinie w 1948 roku. Znaczna jego część pisał Kleiner w szczególnie trudnych warunkach, we Lwowie pod okupacją sowiecką (1939-1941), a później ukrywając się przed Niemcami w wiejskich domach na Zamojszczyźnie. Twórczość Mickiewicza doprowadził w nim do Pana Tadeusza, dając najszersze i najbardziej wszechstronne omówienie tej epopei (343 strony). Pomimo opinii, jakoby Kleiner pozostawił swoje dzieło niedokończone (w sumie liczace ponad 1600 stron), w przekonaniu uczonego było ono kompletne. Ukazał w nim takiego Mickiewicza, który jako jeden z trzech wieszczów najpełniej wyraził związek między poezją a życiem. Twórczość Słowackiego 
wyrastała z konfliktu między dążeniem artysty do ideału a życiem. Autor Balladyny rozwiązywał go stopniowo, osiagając pojednanie ideału i życia dopiero w dziełach mistycznych. U Mickiewicza czyny idą w parze z twórczościa, ciagły wzrost poety to zarazem wzrost artysty. Rzeczywiste przeżycia zaświadcza on zarówno dziełem, jak i życiem, osiagając jako jedyny z wielkiej trójki pełnię ${ }^{34}$.

Zarówno ogromna monografia o Słowackim, jak i pierwszy tom Mickiewicza ugruntowały pozycję Kleinera jako największego polskiego monografisty i najwybitniejszego badacza romantyzmu w dwudziestoleciu międzywojennym. Ocena ostatniej monografii z perspektywy kilkudziesięciu lat wypada jeszcze korzystniej niż Juliusza Słowackiego: „Analizy są bardziej wszechstronne, bardziej wyczerpujące; poznanie romantyzmu głębokie; inspiracji naukowych, dotąd niewykorzystanych, znacznie więcej" ${ }^{35}$ - uzasadniał Jerzy Starnawski. Jak przekonywał z kolei Henryk Markiewicz, wyczerpujące, niemal zupełne omówienia Farysa, Konrada Wallenroda, III części Dziadów, Ksiag narodu i pielgrzymstwa, nade wszystko zaś Pana Tadeusza wszechstronnościa, poziomem interpretacji „górowały nad wszystkim, co o tych utworach wcześniej napisano" 36 .

Spośród niezbyt licznych monografii wieszczów, które ukazały się w dwudziestoleciu, należy wspomnieć jeszcze o książce Krasiński. Życie i twórczość (1928) Tadeusza Piniego, który przez większość życia byl związany ze Lwowem (m.in. jako nauczyciel gimnazjalny). Lata po odzyskaniu niepodległości zaznaczyły się w badaniach historycznoliterackich jako okres wyraźnego spadku zainteresowań Krasińskim. Filozofujący nad miarę poeta wydawał się młodym pisarzom nieaktualny. Zdaniem Andrzeja Waśki arystokratyczne pochodzenie i konserwatywne poglądy autora Irydiona dodatkowo przyczyniały się do tego, że był lekceważony przez literaturoznawców ${ }^{37}$. Coraz częściej odmawiano mu zaszczytnej pozycji trzeciego wieszcza. Kryzys autorytetu Krasińskiego odcisnął też piętno na monografii Piniego. Autor uwydatnił w niej sprzeczności między poglądami, moralnością poety a kreowanymi przez niego walecznymi, szlachetnymi bohaterami. Zarzucano mu, np. Manfred Kridl

34 Por. Matracki 1975, ss. 160, 164.

35 Starnawski 1999 , s. 20.

36 Markiewicz 2000, s. 349.

37 Waśko 2014, s. VII. 
i Piotr Chmielowski, że nazbyt krytycznie ocenił w niej człowieka, że feruje opinie jednostronne, że nie wniknął w psychikę swojego bohatera i nie starał się zrozumieć powodów jego częstego zagłębiania się w filo$z_{\text {zofię }}{ }^{38}$. Rafał Marceli Blüth oskarżył nawet monografistę, że oczernia Krasińskiego ${ }^{39}$. Panowało natomiast dosyć zgodne przekonanie, że o ile portret człowieka nie jest sprawiedliwy, o tyle omówienie jego twórczości wypadło solidnie, wniosło wiele nowych pomysłów.

Niezwiązany ze Lwowem Stanisław Szpotański swoją monografię Adam Mickiewricz i jego epoka pisał w Paryżu. Ukazała się ona drukiem w trzech tomach w latach 1921-1923 w Warszawie. Ambicja autora było ukazanie życia poety na szerokim tle czasów, w których tworzył. Nie zachowując jednak właściwych proporcji, pozwolił filolog, by nadmiar informacji o ludziach z otoczenia wieszcza, o wydarzeniach, o uwarunkowaniach społecznych i historycznych romantyzmu przytłoczył materiał biograficzny. Ponieważ zaś zrezygnował z porządku chronologicznego na rzecz problemowego, książka straciła oś konstrukcyjną, wokół której byłaby budowana narracja. Fakty z życia poety oraz wybiórcze analizy jego utworów pojawiają się w dosyć dowolnej kolejności i niejako przy okazji charakterystyki romantyzmu, która stała się tutaj dominującym żywiołem.

\subsection{Książki, rozprawy, artykuły o polskim romantyzmie w latach 1918-1939}

Powyższy przegląd obrazuje interesująca tendencję: jakkolwiek obszerne monografie wieszczów nadal uważano za ukoronowanie badań literaturoznawcy, w dwudziestoleciu powstało ich zdecydowanie mniej. Monografie jednego utworu dalej należały do rzadkości. Liczna rzesza badaczy romantyzmu wolała dokumentować własne badania publikacjami o mniejszej objętości. We Lwowie, oprócz przodującego Juliusza Kleinera, nadal sporo pisał Wilhelm Bruchnalski, najlepszy okres twórczy rozpoczął Eugeniusz Kucharski, pomnażali bibliografię romantyzmu Wiktor Hahn, Konstanty Wojciechowski, Kazimierz Kolbuszewski, Jan Gwalbert Pawlikowski. Przygotowywał kolejne edycje dzieł pisarzy romantycznych Tadeusz Pini. Do głosu doszło młodsze

38 Kridl 1928, ss. 340-341.

39 Blüth 1928, s. 5. 
pokolenie filologów: Stefania Skwarczyńska, Stefan Kawyn, Stanisław Łempicki, Ryszard Skulski, Zygmunt Szweykowski, Rafał Marceli Bluth, Władysław Floryan. Wspierał je filolog klasyczny Jerzy Kowalski i okazjonalnie anglista Władysław Tarnawski.

W Krakowie kontynuowali badania nad romantyzmem Stanisław Windakiewicz i Józef Tretiak, jednak publikowali wyraźnie mniej niż przed rokiem 1918. Często sięgał po twórczość tej epoki Ignacy Chrzanowski, ale domena uczonego były studia nad literatura przedrozbiorowa. Marian Szyjkowski badał głównie recepcję polskich romantyków w czeskiej Pradze. Stefan Kołaczkowski sięgał do nich sporadycznie. Dopiero od roku 1931, kiedy do Krakowa przybył z Wilna Stanisław Pigoń, stał się on w tamtym środowisku liderem badań romantyzmu. Wśród reprezentantów polonistyki warszawskiej, prężnie rozwijanej w reaktywowanym polskim uniwersytecie (1915), najwięcej romantyzmem zajmował się Józef Ujejski, po nim Zofia Szmydtowa. Sporo też publikował Tadeusz Makowiecki. Powracali do tej literatury Wacław Borowy i Zygmunt Lubicz-Zaleski, a tylko czasami sięgał po nią Julian Krzyżanowski. W Uniwersytecie Wileńskim w pierwszej dekadzie dwudziestolecia badał spuściznę po Mickiewiczu i innych pisarzach tego czasu wspomniany Stanisław Pigoń, a po jego odejściu najwięcej publikował o nich Stanisław Cywiński. Wartościowe prace w tamtych latach pozostawili po sobie Konrad Górski i Manfred Kridl. Młodą polonistykę lubelska tworzyli uczeni związani z powstałym w 1918 r. w tym mieście uniwersytetem. Niestrudzonym badaczem romantyzmu okazał się tam Henryk Życzyński, niemal osamotniony na tym polu naukowej aktywności (sporadycznie wspierał go Ludwik Kamykowski). Najmniejsze zainteresowanie tą epoka wykazywali przedstawiciele młodej polonistyki poznańskiej: jedynie Tadeusz Grabowski i Stanisław Dobrzycki pozostawili nieliczne publikacje jej poświęcone.

\subsubsection{Bilans lwowskiej polonistyki}

Przegląd najważniejszych dokonań filologicznych związanych z polskim romantyzmem warto zacząć od prac lwowskich uczonych. Część badaczy piszących w dwudziestoleciu doczekała się bardziej szczegółowych zestawień bibliograficznych opublikowanych w Stowniku współczesnych pisaray polskich pod red. Ewy Korzeniewskiej, sylwetki innych znalazły się w dziesięciotomowym Stowniku badaczy literatury polskiej pod red. Jerzego 
Starnawskiego (Łódź 1994-2009). Dlatego uwzględniłem jedynie wybrane pozycji z dorobku filologów.

Pomnikowym osiagnięciem Juliusza Kleinera, kolejnym po monografiach wieszczów, stała się edycja Džieł wszystkich Juliusza Słowackiego. W 1924 r. ukazał się tom I poprzedzony ogromnym wstępem (prawie 200 stron) pod tytułem „O metodach wydania «Dzieł wszystkich» Słowackiego". Uznano go za najwybitniejszy wykład z zakresu edytorstwa (Manfred Kridl nazwal go prawdziwym ,poematem filologicznym”). Kolejne ukazujące się tomy dowodziły, że „takiego przeorania się przez cały materiał autografów poety i takiego wyzyskania nagromadzonych informacji dla tekstologii Słowackiego nie zrobił nikt przed Kleinerem i już chyba nie zrobi”"40. Wydanie zostało zaplanowane na 16 tomów, ale w latach 1924-1933 ukazały się tomy I-VII (utwory wydane za życia poety) oraz tomy IX-XI (z rękopisów). Każdy utwór był opatrzony wzorcowym komentarzem krytycznym. Co najmniej do drugiej wojny światowej to zbiorowe wydanie stanowiło szczytowe osiagnięcie polskiego edytorstwa. Po wojnie, w 1952 r. wznowiono Dzieła wsaystkie i doprowadzono je do końca (w 1975 r.).

Zasługi edytorskie Kleinera widoczne są też w pojedynczych utworach romantyków wydawanych w serii Biblioteka Narodowa, zawsze wzorcowo opracowanych. Należą tu Beniowski (1920), Prz̨edświt (1920), Nie-Boska komedia (1921) i Balladyna (1923). Mistrzowskie opracowanie Beniowskiego uznano za najlepsze w całej przedwojennej serii Biblioteka Narodowa. Wacław Borowy postulował nawet (w 1929 r.), by za Beniowskiego przyznać Kleinerowi buławę edytorską.

Wśród ważniejszych publikacji Kleinera dotyczących Mickiewicza trzeba wymienić popularną rozprawę „O «Panu Tadeuszu» - książce budującej” (1925), „Kompozycja «Dziadów» części III” (1928), „Mickiewicz na tle literatury światowej” (1929), „Imię «czterdzieści i cztery» czy nazwanie czterdziestką i czwórką” (1929), „Mickiewicz et son épopée nationale" (1935). Słowackiemu poświęcił jeszcze jedną książkę - syntetyczne omówienie twórczości pt. Stowacki (1938) oraz studia prezentujące nowe, po wydaniu pięciotomowej monografii, ustalenia: „Her w zaświatach (Z komentarza rapsodu I «Króla-Ducha»”) - w 1928 roku, „Polska mistyka romantyczna wobec koncepcji paralelizmu światów”

\footnotetext{
${ }^{40}$ K. Górski 1961, s. 21.
} 
(1931), „Miltonowski motyw bóstw uchodzących w «Królu-Duchu»” (1934). Z prac o Krasińskim trzeba wspomnieć o szkicu „Z badań nad poezją wielkich romantyków. 1. «Grażyna» jako poemat polityczny. 2. Ojciec i syn w «Irydionie»" (1928). Osobny kierunek filologicznych dociekań uczonego stanowia studia nad twórczościa Aleksandra Fredry (koncentrują się one najczęściej wokół Zemsty i Ślubów panieńskich).

W pracach Kleinera $z$ lat 1927-1939 widać dwie dominujące tendencje: do ukazania wielkiej osobowości twórcy (zwłaszcza w ostatnim, mistycznym tomie Stowackiego i później w tomie I Mickiewicza) i do stworzenia wielkiej syntezy historii literatury. To drugie dążenie odzwierciedlają dwa znacznie różniące się opracowania dziejów naszego piśmiennictwa: po niemiecku i po polsku, a w nich dwa ujęcia romantyzmu. W 1929 r. ukazało się dwutomowe Die polnische Literatur (w wielotomowym podręczniku o literaturze pod redakcją Oskara Walzla pt. Handbuch der Literaturwissenschaft). To eksportowa wersja historii polskiej literatury dla cudzoziemców. Napisana nienaganna, w dodatku kwiecistą niemczyzną (Kleiner znał ten język niemal na równi z ojczystym) do dziś jest uważana za najlepsze opracowanie naszej literatury w języku obcym. W latach 1938-1939 ogłosił dwutomowy Zarys dziejón literatury polskiej, ujęcie syntetyczne, przeznaczone dla zdolniejszych polskich studentów, jako że stanowiło podręcznik trudniejszy od innych tego typu opracowań. Przełomowe dla metodologii badań literackich znaczenie miała rozprawa „Historyczność i pozaczasowość w dziele literackim” (1936), w której Kleiner sformułował teorię arcydzieła. W procesie interpretacji najważniejsza jest ocena, która decyduje, czy utwór jest arcydziełem. Uczony uznał badacza za pośrednika między pisarzem a czytelnikiem. Kontakt z wielkimi dziełami nobilituje uczonego, jednak kontakt duchowy czytelnika z dziełem tworzy sam poeta, nie badacz. Kleiner, obcując ustawicznie z najwybitniejszymi twórcami, nazywał siebie sługą wielkości.

Wilhelm Bruchnalski pogłębiał studia nad Mickiewiczem, wśród których uwage zwracaja prace komparatystyczne, np. wykazujące związki Džiadón i Pana Tadeusza z powieściami René Chateaubrianda („Mickiewicza «Dziady» wileńskie wobec Chateaubrianda powieści «Atala» i «René»” - z 1925 roku, „Paralele niektóre między «Panem Tadeuszem» a «Męczennikami» Chateaubrianda" - z 1936 roku) oraz Konrada Wallenroda z Romeo i Julia Szekspira („«Romeo i Julia» - «Konrad Wallenrod». Motyw pieśni porannej” - z 1928 roku). Znacząco też przyczynił się 
do popularyzacji twórczości poety jako edytor jego dzieł (m.in. w serii Wielka Biblioteka w latach 1922-1925 ukazywały się kolejno Ballady i romanse, Grażyna, Pan Tadeusz, Sonety - Sonety krymskie, Konrad Wallenrod). Kiedy sejm Drugiej Rzeczypospolitej uchwalił wydanie Drieł wszystkich Mickiewicza, to właśnie Bruchnalski ustalił szczegółowo zasady edycji i układ każdego tomu (w rozprawie „Próba kanonu wydawniczego w zastosowaniu do zbiorowej edycji «Dzieł wszystkich» Mickiewicza" z 1923 r. jako pierwszy nakazał włączyć do wydania zbiorowego również listy i luźne notatki). W 1934 r. ustalił brzmienie tekstu Pana Tadeusza, który umieścił w tomie IV.

Eugeniusz Kucharski rozwijał badania poświęcone Fredrze, które w dwudziestoleciu osiagnęły apogeum. Zarówno przed habilitacja, jaki i po jej uzyskaniu na podstawie książki Fredro a komedia obca. Stosunek do komedii wtoskiej (1921) publikował kolejne artykuły i rozprawy, wśród których do ważniejszych należą „«Wychowanka» Fredry a Goldoniego «La Pamela» i «Pamela maritata»” (1919), „Źródła i podstawy niektórych pomysłów i wątków fredrowskich” (1920), „O narodowości Geldhaba” (1921), „Epoka Fredry i jej wizerunek w komedii 1815-1848” (1922) i zwłaszcza „Chronologia komedyj i niektórych pomniejszych utworów Al. Fredry” (1923) oraz „Milczenie Fredry” (1926). Ugruntowywał nimi pozycję najlepszego fredrologa w Polsce. Współpraca z Biblioteką Narodową już na początku dwudziestolecia wydała owoce w postaci edycji trzech komedii Fredry: Śluby panieńskie (1920), Zemsta (1920) i Pan Jowialski (1921). Ponieważ Kucharski równolegle $\mathrm{z}$ historia literatury zajmowal się jej teorią, przeto jego wstępy w wydaniach BN były szczególnie odkrywcze, przynosiły oryginalne interpretacje i odbijały się głośnym echem w środowisku polonistów. „Wydania te należą do najlepszych opracowań literacko-naukowych, jakie posiada nasza literatura" ${ }^{41}$ - z satysfakcja przyznawał Kleiner, oceniając jego dorobek w roku 1921. Największym jednak sukcesem wydawniczym Kucharskiego okazała się edycja Pism wsaystkich Fredry. Z zaplanowanych ośmiu tomów w latach 1926-1927 ukazało się sześć. Otwierający tom I wstęp pt. „Życiorys literacki” „godzi się nazwać arcydziełem biografii i charakterystyki literackiej”" ${ }^{\prime 2}$ - powtarzał za Kleinerem ówczesny dziekan

${ }^{41}$ DALO f. 26, op. 7, spr. 903, k. 55: Rada Wydriału Humanistycznego UJK do Ministerstwa WRiOP w sprawie nominacji Eugeniusza Kucharskiego, 21 lipca 1921 r.

${ }^{42}$ DALO f. 26, op. 5, spr. 1028: teczka osobowa Eugeniusza Kucharskiego, k. 90. 
Wydziału Humanistycznego Uniwersytetu Jana Kazimierza Edmund Bulanda we wniosku w sprawie mianowania Kucharskiego profesorem nadzwyczajnym, skierowanym 27 grudnia 1926 r. do Ministerstwa Wyznań Religijnych i Oświecenia Publicznego. Pomimo że niekompletna, edycja Kucharskiego była uważana za najważniejsze i podstawowe wydanie komedii Fredry aż do opracowania po drugiej wojnie przez Stanisława Pigonia i Krystynę Czajkowską całego dorobku pisarza. Poza Fredrą zajmował się również Kucharski twórczością poetów romantyzmu - Słowackim („Glosy do «Kordiana»” - 1920; „Jabłoń z gwiazd w «Anhellim»” - 1921) i Malczewskim („Kilka uwag o życiu i pismach A. Malczewskiego" - 1923).

Spośród lwowskich filologów kontynuujących po roku 1918 badania nad romantyzmem warto wymienić Wiktora Hahna, Konstantego Wojciechowskiego, Jana Gwalberta Pawlikowskiego i Tadeusza Piniego. Hahn opracował i wydał w serii Biblioteka Narodowa aż siedem utworów - sześć powieści (Karpackich górali Józefa Korzeniowskiego w 1923 i 1928 oraz Józefa Ignacego Kraszewskiego Budnika - 1923, Powrót do gniazda - 1923 i 1928, Driecie Starego Miasta - 1924 i 1928, Historie o Janaszu Korczaku i pieknej miecznikónnie - 1924, Morituri - 1925), a także Mindowego Słowackiego (1921 i 1924). Konstanty Wojciechowski udoskonalał badania komparatystyczne, włączając w nie m.in. twórczość Mickiewicza („Pan Tadeusz”, Adama Mickiewicza a romans Waltera Scotta1919, „Motywy «Wawerleya» W. Scotta w «Grażynie» i w «Konradzie Wallenrodzie»: Halban jako postać kierownicza" - 1919). On również opracował i wydał w serii Biblioteka Narodowa kilka powieści: Spekulanta i Kollokacje Korzeniowskiego (obie w 1921 roku), Stara baśń Kraszewskiego (1922), Listopad Henryka Rzewuskiego (1923). Jan Gwalbert Pawlikowski ogłaszał rezultaty kolejnych badań nad Słowackim mistycznym: „O układzie dialogów genezyjskich Słowackiego” (1921), „Z genezy kompozycji «Króla-Ducha» («Król-Duch»a «Beniowski»») (1922), „Chronologia pism genezyjskich i rozwój genezyjskich pomysłów Słowackiego” (1927), „Na marginesie pism genezyjskich Słowackiego” (1928), ,Społeczno-polityczne idee Słowackiego w dobie mistycyzmu” (1930), „O tzw. «Teogonii» Juliusza Słowackiego” (1932), „, O potrzebie krytycznego wydania pism genezyjskich Słowackiego" (1938). W 1924 r. ukazało się w Ossolineum monumentalne dwutomowe wydanie Króla-Ducha z imponującym komentarzem, przygotowane przez jego syna Michała. Tadeusz Pini oprócz omówionej już monografii nie pozostawił 
wielu publikacji związanych z romantyzmem (warto tu wymienić artykuł „«Dziady» a Maryla” z 1933 r.), ale oddał duże usługi jako edytor Driet czterech wieszczów: Mickiewicza (pięć tomów z lat 1933-1934), Słowackiego (trzy tomy z 1933 r.), Krasińskiego (dwa tomy z 1934-1935 r.), Norwida (z 1934 r.) - wszystkie z własnymi wstępami i komentarzami.

Pokolenie młodszych absolwentów i pracowników lwowskiej polonistyki, debiutujących naukowo w wolnej Polsce, reprezentuje Stefania Skwarczyńska, jedna z najlepszych studentek Kleinera. Już w wieku 23 lat uzyskała doktorat na podstawie ksiazżi Ewolucja obrazón u Stowackiego (1925). Krocząc śladami mistrza, umiała jednak rozwijać własne badania nad Mickiewiczem i Słowackim, wzbogacając je o nowe wattki. Komparatystycznych zainteresowań dowiodła w rozprawach: „Przyczynek do badań nad mistyką Słowackiego” (1925), „"Genezis z Ducha» Słowackiego wobec «Confessiones» św. Augustyna” (1930), „Słowacki i Chateaubriand" (1932). Teoria literatury, z której jako pierwsza kobieta w Polsce habilitowała się (1937), odcisnęła piętno na studium „Struktura tragizmu «W Szwajcarii» Słowackiego" (1939). Wyjątkowo odkrywcza na tle ogromnej dotychczasowej bibliografii przedmiotowej pierwszego wieszcza okazała się jej książka Rozwój watkón i obrazón w twórczości Mickiewicza (1934). Podobnie nowatorski charakter wykazywała rozprawa ujmująca romantyczną syntezę sztuk pt. „Wartość treściowa kolorów w romantyzmie a dzisiaj na tle badania relacji między twórcą a odbiorcą" (1932).

Wierny twórczości romantyków pozostawał Stefan Kawyn, który w dwudziestoleciu międzywojennych opublikował trzy książki: komparatystyczną rozprawę doktorską Stowacki - Heine (,Beniowski” - „Niemcy. Baśn zimowa”) w 1930 r., Ideologie stronnictw politycznych wobec Mickiewicza 1890-1898 (1937) oraz monografię Cyganeria warszanskea (1938), która stała się podstawą jego habilitacji (uzyskanej w 1945 r. na KUL-u w Lublinie). Zygmunt Szweykowski jako najlepszy w międzywojennej Polsce znawca powieści (po śmierci Konstantego Wojciechowskiego) opracowal trzy edycje pisarzy romantycznych w serii biblioteka Narodowa: Murdeliona Zygmunta Kaczkowskiego (1925), Owruczanina Michała Czajkowskiego (1927) i Pamiatki Soplicy Henryka Rzewuskiego (1927). Stanisław Lempicki, kierownik katedry oświaty i szkolnictwa UJK, jako polonista i historyk literatury pozostawił kilka odkrywczych studiów poświęconych dziełom Mickiewicza: „Nieznany najdawniejszy przekład «Dziadów» wileńskich na język niemiecki” (1929), „O «Panu 
Tadeuszu» w stulecie ukazania się arcydzieła” (1934), „Glosy do «Pana Tadeusza»" (1934). W tej ostatniej wykazał liczne analogie między Panem Tadeuszem a Odyseja Homera. Trzydziestokilkustronicową rozprawę poświęcił jednemu z sonetów krymskich („Nowa interpretacja sonetu Mickiewicza «Ajudah»" - 1928). Interesował się też twórczością Słowackiego: „Miłość dantejska w poemacie «W Szwajcarii»” (1925), „Przyjaciel Horsztyńskiego” (1926), „Wigilie Słowackiego” (1928). Ryszard Skulski, należący wśród lwowskich polonistów do metodyków nauczania literatury i języka polskiego, badał dzieje recepcji Mickiewicza (rozprawa „Pierwsze ślady recepcji Mickiewicza w szkole polskiej” z 1934 r. i jubileuszowa monografia „Pan Tadeusz”, jako ksiazka školna z 1934 r.).

Szczególne znaczenie dla badań twórczości Mickiewicza ma dokonanie filologa klasycznego UJK Jerzego Kowalskiego. Chodzi o genialny przekład z francuskiego wykładów lozańskich, które znalazły się w VII tomie Driet wszystkich wieszcza wraz z ogromnym wstępem-monografia oraz ponad stustronicowym dodatkiem krytycznym. Było to zwieńczenie kilku lat drobiazgowych studiów filologicznych, którym towarzyszyły rozprawy publikowane po polsku i po francusku, m.in. „Czy zginie dla Polski? O wykładach lozańskich Mickiewicza” (1926), „Note sur la première édition monographique des leçons de Mickiewicz à Lausanne” (1926), „Adam Mickiewicz à Lausanne (1839-1840)” (1927). Tłumaczenie Kowalskiego wraz z opracowaniem uznano za majstersztyk edytorstwa. Tadeusz Mikulski dowodził, że

Kowalski dokonał przekładu jakby pod szept Mickiewicza z zasobów jego prozy utrwalonej w rozmowie i korespondencji, przerzucając całe złoża dokumentów, by wytropić słuszność lub prawdziwość użytego w przekładzie rzeczownika czy przymiotnika ${ }^{43}$.

Do lwowskich badaczy Mickiewicza należy jeszcze Rafał Marceli Blüth, student Politechniki Lwowskiej, który dziwnym zrządzeniem losu został uczestnikiem seminarium naukowego Juliusza Kleinera ${ }^{44}$. Niezwiązany zawodowo z żadną uczelnią prowadził nowatorskie studia nad Mickiewiczem, Conradem i Dostojewskim oparte na psychoanalizie, przy czym to dzieło literackie, a nie list czy pamiętnik pisarza, stanowiło dla niego dokument psychologiczny. U Mickiewicza interesował go

${ }^{43}$ Mikulski 1976, s. 51.

44 Zob. Chrostek 2016, ss. 208-209. 
rosyjski i drezdeński okres życia i twórczości, czego pokłosiem są m.in. publikacje: „Mickiewicz wobec ruchu literackiego w Rosji w okresie 1826-1829” (1925/1926), „Mickiewicz i Rylejew pod pomnikiem Piotra Wielkiego” (1927), „Do przyjaciół Moskali” (1927), „Adam Mickiewicz a Teodor Tiutczew” (1928), „Chrześcijański Prometeusz. Wpływ Boehmego na koncepcję III cz. «Dziadów»” (1929). Obszerna rozprawa „Psychogeneza «Snu w Dreźnie»” (1925) została uznana przez współczesnych za mistrzostwo psychoanalizy.

\subsubsection{Zasługi innych polonistyk uniwersyteckich (krakowskiej, warszawskiej, wileńskiej, lubelskiej i poznańskiej)}

W krakowskim środowisku polonistycznym badania epoki romantyzmu osiagnęły znacznie skromniejsze rozmiary niż we Lwowie. Niewiele napisał po powrocie do Krakowa w 1920 r. Józef Kallenbach (trzy wstępy do trzech edycji Pism Mickiewicza, Słowackiego i Krasińskiego w 1922 r.), sporadycznie udzielał się na ten temat Józef Tretiak (zmarł w 1923 r.). Nawet aktywny naukowo w ciagu całego dwudziestolecia Stanisław Windakiewicz pozostawił nieliczne artykuły (np. „Próby i pomysły dramatyczne Mickiewicza" z 1933 r.) i dwie obszerniejsze prace popularnonaukowe: Adam Mickiewicz: Życie i dzieła (1935) oraz Romantyzm w Polsce (1937). Zaletą tych publikacji jest próba obiektywnego spojrzenia na romantycznych wieszczów, uczony bowiem nie tolerował brązownictwa w badaniach naukowych. Wadą są płytkie, powierzchowne interpretacje utworów literackich. Windakiewicz po dawnemu (tak jak przed rokiem 1918) zdecydowanie wolał uprawiać komparatystykę, wyszukiwać rozliczne analogie między polskimi i zagranicznymi dziełami, niż zajmować się ich analizą. Nie lubił przeto filologicznych komentarzy ani tekstologicznych dociekań.

Filologiem bardziej płodnym, nie tylko w zakresie prac o romantyzmie, był Ignacy Chrzanowski, który jednak w dwudziestoleciu starał się nie zbaczać z kursu wyznaczonego przez twórczość największych poetów. Pisał zatem o Mickiewiczu: „«Oda do młodości» na tle epoki” (1919), „Mickiewicz wobec Kościoła w ostatnim kursie prelekcji paryskich” (1921), „Wzniosłość w «Panu Tadeuszu»” (1934). Pamiętał o Słowackim: „«Godzina myśli». (Z wykładów o Słowackim)” (1922), „Czy «Lilla Weneda» jest arcydziełem dramatu?” (1924), „Uwagi nad prologiem «Kordiana»” (1925). Powracał też do Krasińskiego: „«Przedświt» 
a prelekcje paryskie” (1920), „Poezja Krasińskiego. Próba syntezy” (1928). W badaniach historycznoliterackich odegral jednak Chrzanowski swoją rolę przede wszystkim jako znawca literatury staropolskiej i oświecenia.

Z Krakowem przejściowo związał swoje losy Marian Szyjkowski, student i doktor wypromowany we Lwowie, który w 1923 r. jako profesor zwyczajny rozpoczął pracę na Uniwersytecie Karola w Pradze. Swoje zainteresowania romantyzmem ograniczył do recepcji pisarzy tego okresu w Czechach, co udokumentował m.in. w rozprawach publikowanych w cyklu Polskie peregrynacje do Pragi i Karlowych Warów: „Kazimierz Brodziński w Czechach” (1935), „Mickiewicz jedzie do Pragi” (1935), „Wileńscy filomaci w Pradze” (1935). Poza tą serią ukazała się jeszcze w 1939 r. „Pierwsza recepcja Mickiewicza w czeskiej literaturze. (Zagadnienie ballady)”. Wyniki badań ogłaszał również w języku czeskim. Pewien wkład w badania romantyzmu wniósł także Stefan Kołaczkowski, głównie jako autor pracy Dwa studia. Fredro-Norwid (1934) zawierającej obszerne rozprawy „Osobowość i postawa poetycka Fredry” oraz „Ironia Norwida”.

W 1931 r., wraz z objęciem w Uniwersytecie Jagiellońskim Katedry Literatury Polskiej przez Stanisława Pigonia, wzrasta rola krakowskiej polonistyki w badaniach romantyzmu. Uczony, związany wcześniej z Uniwersytetem Poznańskim (1919-1921) oraz Uniwersytetem Stefana Batorego w Wilnie (1921-1931), przybywał do Krakowa jako wytrawny znawca twórczości Mickiewicza. Jak wyliczył Jerzy Starnawski, w samym tylko dziesięcioleciu wileńskim napisał on około 120 tekstów - artykułów, małych przyczynków i zupełnych drobiazgów filologicznych (np. bibliograficznych) - dotyczących bardziej lub mniej Mickiewicza ${ }^{45}$. Autorem Driadów zajmował się zresztą przez całe życie (zmarł w 1968 r.), co uprawniało go do zatytułowania jednej z książek Zawsze o Nim (1960). Wychowany i wykształcony w atmosferze kultu romantyzmu, początkowo ulegał Pigoń fascynacji Słowackim, ale szybko wyparł się tego zamiłowania i trwale przywiązał się do Mickiewicza. Jak dowiodła Maria Janion, u źródeł takiej reorientacji leżało chłopskie pochodzenie Pigonia, jego chłopska mentalność, którą eksponował, sygnując swoje wczesne prace pseudonimami „Chłop” i „Helota” oraz bardziej dobitnie

\footnotetext{
45 Starnawski 1997b, ss. 111-112.
} 
wypowiadając się w pamiętniku $Z$ Komborni w świat. Tym należy tłumaczyć jego przywiązanie do opinii gromady, zbiorowości, do przedkładania interesu wspólnoty ponad dobro indywidualne. U Słowackiego raził Pigonia indywidualizm jego bohaterów. Etos zbiorowości odnajdywał u Mickiewicza. W literaturze zawsze poszukiwał wartości etycznych i stawiał je nieporównanie wyżej od jej wartości estetycznych ${ }^{46}$. Szczególnie doceniał nurt patriotyczny w twórczości nie tylko romantyków.

W bogatym dorobku Pigonia przypadającym na dwudziestolecie międzywojenne znajduje się zaledwie jedna monografia - „Pan Tadeusz”. Wrarost, wielkość $i$ sława (1934), ponieważ był on „głównie mistrzem «miniatury» historycznoliterackiej" ${ }^{47}$, jak to trafnie ujął Julian Maślanka. Szereg artykułów i przyczynków pomieścił w kilku książkach zbiorowych: „Z epoki Mickiewicza”. Studia i sqkice (1922), Gtosy sprzed wieku. Szkice z dziejón procesu filareckiego (1924), Z dawnego Wilna. Sqkice obyczajowe i literackie (1929), Na wysynach romantyzmu. Studia bistorycznoliterackie (1936). Sporo uwagi poświęcił Pigoń mistycyzmowi Mickiewicza i jego bliskiej współpracy z Andrzejem Towiańskim. Doktoryzował się na podstawie rozprawy $O$ „Ksiegach narodu i pielgraymstwa polskiego” A. Mickiewricza (1911). Po 1918 r. wracał do tej problematyki: „Idee St. Martina w «Księgach narodu i pielgrzymstwa»” (1920), „Adoracja Towiańskiego” (1926), „Adam Mickiewicz w Kole Sprawy Bożej” (1932), „Towiański na Litwie" (1932). Bardziej niż dociekania biograficzne interesował go tekst utworów literackich. Badania rękopisów wersji pośrednich i ostatecznych tekstu z czasem stały się jego pasja, która ,prowadziła do badań genetycznych, do rekonstrukcji etapów rozwojowych dzieł literackich i odtwarzania procesu twórczego" ${ }^{48}$. Nic dziwnego, że stał się Pigoń jednym z najlepszych polskich edytorów, zwłaszcza jako wydawcza Pana Tadeusza w serii Biblioteka Narodowa (1925) i później jako autor ogromnego, blisko dwustustronicowego dodatku krytycznego do Pana Tadeusza w IV tomie Driet wszystkich Mickiewicza (1934). Pigoń należał do komitetu redakcyjnego wydania sejmowego dzieł. Utworom Mickiewicza poświęcał jednak nierównomierną uwagę, preferując te najbardziej znane, np. „Cela Konrada. Przyczynek do topografii «Dziadów» części III” (1921), „Do źródeł «Dziadów» wileńsko-kowieńskich”

\footnotetext{
46 Janion 1986, ss. 125-126.

47 Maślanka 1985, s. 18.

${ }^{48}$ Ibidem, s. 22.
} 
(1930), „Ze studiów nad tekstem «Pana Tadeusza». Trzy notatki” (1928), „Sąd nad Polską w «Panu Tadeuszu»” (1934).

$Z$ innych poetów romantycznych sporym zainteresowaniem darzył Pigoń Seweryna Goszczyńskiego, czemu wyraz dawał w kolejnych artykułach: „S. Goszczyńskiego nieznana powieść poetycka o Wernyhorze” (1925), „S. Goszczyński w sporze z kołem «Sprawy». Kartka z dziejów towianizmu” (1928), „Uwagi o genezie i zakroju «Kościeliska» S. Goszczyńskiego” (1929), „Oratorium wieszcze S. Goszczyńskiego” (1936). Zdarzało się uczonemu sięgać do twórczości Norwida: „Z niedrukowanej korespondencji Norwida” (1921), „Norwid o «Panu Tadeuszu»” (1925). Słowackim i Krasińskim niewiele się zajmował: „Uwagi o prologu «Kordiana»” (1927), „Krasiński w «Zwolonie» Norwida” (1937).

W Warszawie w 1919 r. rozpoczął wykłady przybyły tu z Krakowa Józef Ujejski, polonista, który szczególnie upodobał sobie romantyzm. Posiadając już na swoim koncie wartościowe prace z zakresu tej epoki, rozwijał badania nad życiem umysłowym i obrazem duchowym pokolenia Mickiewicza. Zajmował się nie tylko twórczością poetów największych. W 1921 r. opublikował monografię Antoni Malczewski. Poeta i poemat - pierwszą tego typu pracę poświęconą autorowi Marii. Książka stanowi solidne opracowanie jego biografii, światopoglądu oraz najważniejszego utworu. Metodologicznie nawiązuje do modernistycznych założeń Wilhelma Diltheya. Z ważniejszych studiów o Mickiewiczu warto przypomnieć „Byronizm i skottyzm w «Konradzie Wallenrodzie»” (1923) oraz przewrotnie zatytułowany artykuł „Zapomniany artysta” (1925), w którym badacz upomina się o zainteresowanie walorami estetycznymi utworów Mickiewicza. Wysoko cenione były jego prace o Słowackim, np. „Słowacki jako poeta dumy” (1927). „Trudno już dzisiaj wyobrazić sobie interpretację Kordiana i Anbellego bez uwzględnienia sądów Ujejskiego"49 - napisze po latach z uznaniem Zdzisław Libera. O Krasińskim wypowiadał się krytycznie, zwłaszcza w rozprawie „W stulecie «Irydiona»" (1937). Doceniał natomiast Norwida, publikując z wnikliwymi komentarzami listy tego poety do Augusta Cieszkowskiego i Zygmunta Krasińskiego (1926). Był też Ujejski najlepszym znawcą polskiego mesjanizmu, któremu poświęcił kilka książek: Król Nowego Izraela. Kartka z. dziejów mistyki wieku oświeconego (1924), O cene absolutu.

\footnotetext{
${ }^{49}$ Libera 1964, s. 286.
} 
Rzeczo o Hoene-Wrońskim (1925) i zwłaszcza Drieje polskiego mesjanizmu do powstania listopadowego wtacznie (1931). Uczony badał ten prąd umysłowy od XVI w., ukazując ewolucję pojęcia narodu wybranego w Polsce jeszcze przed zaborami. Wydał też z własnym opracowaniem wiele dzieł romantycznych, m.in. w serii Biblioteka Narodowa Kordiana (1919), Anbellego (1920), Marie Malczewskiego (1922), Konrada Wallenroda (1924), Marie Stuart Słowackiego (1928).

Cyprian Norwid stał się jednym z najbardziej interesujących poetów dla filologów związanych w dwudziestoleciu z Uniwersytetem Warszawskim. Często pisała o nim Zofia Szmydtowa, studentka Kleinera (z czasu jego kilkuletniego pobytu w Warszawie), która doktoryzowała się (1917) na podstawie rozprawy o Andrzeju Towiańskim. U Norwida badała jego związki z antykiem (np. „Norwida przekład ody Horacego «Ad Pompeium»” - 1923, „Norwid jako tłumacz Homera” - 1929, „Platon w twórczości Norwida” - 1936), z dawniejszymi polskimi pisarzami („Norwid a Kochanowski” - 1925, „Norwid wobec tradycji literackiej" - 1925), ale też analizowała poszczególne jego utwory (,Twórczość dramatyczna Norwida” - 1935, „Nowele Norwida" - 1938). Habilitowała się na podstawie książki O misteriach Norwida (1932). Zajmowała się również twórczością Mickiewicza (m.in. „Idea wyzwolenia narodu w «Wallenrodzie»” - 1919, „Bajka o chłopie i żmii w opracowaniu Mickiewicza” - 1920, „«Dziady» wileńskie w świetle dialogów Platona” - 1933, „Osobowość Mickiewicza” - 1934). Z pomniejszych poetów sporo uwagi poświęciła Teofilowi Lenartowiczowi („Lenartowicz w wykładzie szkolnym” - 1918, „Teofil Lenartowicz. W setną rocznicę urodzin” - 1922, „Mazowsze w poezji Lenartowicza” - 1934). Niekiedy uprawiała też komparatystykę literacką („Dante a romantyzm polski" - 1929).

Wacław Borowy, od 1920 r. pracownik Biblioteki Uniwersytetu Warszawskiego (doszedł tam do stanowiska dyrektora), następnie od 1937 r. (po wczesnej śmierci Józefa Ujejskiego) profesor w Katedrze Historii Literatury Uniwersytetu Warszawskiego, darzył Norwida szczególnym sentymentem. Śledził wszystko, co dotyczyło jego twórczości, recenzował cudze prace o Norwidzie i pisał własne artykuły, z reguły drobne teksty, w których rozpoczynał rozważania od niewielkiego zagadnienia, by dojść do problemów zasadniczych. Zbierał je pod wspólnym tytułem Norwidiana i publikował co kilka lat, oznaczając, jakiego okresu dotycza: Norwidiana 1921-1924 (druk w 1925 r.), następnie za 
lata 1925-1929 (1930), 1930-1935 (1937). Większe teksty publikował oddzielnie, np. „«Anioł woła». Interpretacja czterech zwrotek Norwida” (1935), „Spory o Norwida” (1936). Z romantyków zajmował się także Mickiewiczem: „Zagadkowość w kompozycji «Dziadów» i próba jej wyjaśnienia” (1922), „Nowogródczyzna mickiewiczowska” (1925). Sięgał też do Fredry: „Ze studiów nad Fredrą: O «Pawle i Gawle»; «Trzy po trzy»; Akcja «Zemsty»" (1921).

Kolejnym warszawskim norwidologiem był Tadeusz Makowiecki, który doktoryzował się na podstawie dysertacji Młodzieńncze poglady Norwida na sztuke (druk w 1927 r.). Niezwiązany zawodowo z Uniwersytetem Warszawskim, pracujący w różnych instytucjach kulturalnych stolicy, publikował liczne artykuły i przyczynki o Norwidzie. Zestawiał jego twórczość z dziełami innych pisarzy - staropolskich („«Promethidion» Norwida a «Dworzanin» Górnickiego” - 1928) albo współczesnych wieszczowi („T.T. Jeż a Norwid” - 1928). Z innych znaczniejszych studiów godne uwagi sa „Listy Cypriana Norwida z roku 1863” (1929), „Norwid wobec powstania styczniowego" (1929), „Z batalii o Norwida” (1935/1936). W latach 30. XX w. ,zdradzi1" ulubionego poetę na rzecz Wyspiańskiego, ale po drugiej wojnie światowej chętnie do niego wracał.

Zygmunt Lubicz-Zaleski, pomieszkujący na przemian w Paryżu i Warszawie, zawodowo związany z Uniwersytetem Warszawskim od 1929 r., publikował większość artykułów i rozpraw po francusku. Do najważniejszych należą te o Mickiewiczu i Słowackim: „Michelet, Mickiewicz et la Pologne” (1928), „Adam Mickiewicz, poéte et dictateur moral de Pologne” (1929), „Jules Słowacki, l'Ouvrier de Dieu” (1927). Po polsku ogłosił studium „Wartości żywe mesjanizmu polskiego” (1936).

Julian Krzyżanowski, który w 1934 r. objął Katedrę Historii Literatury Polskiej w Uniwersytecie Warszawskim (wcześniej wykładał za granica), rzadko sięgał do twórczości romantyków. Krasińskiemu poświęcił artykuł „Masynissa i jego rola w «Irydionie»” (1923), po angielsku opublikował studium porównawcze „Mickiewicz and Pushkin” (1928), jednej z powieści Kraszewskiego dotyczy praca „Zagadka «Jermoły» (Kraszewski i George Eliot)" z 1939 r.

W środowisku wileńskim, obok Stanisława Pigonia, a zwłaszcza po jego przejściu do Krakowa, aktywnością naukową wyróżniał się Stanisław Cywiński. Doktoryzowany na podstawie opracowania twórczości Norwida edytowanej w serii Biblioteka Narodowa (1924), habilitowany z rozprawy o Samuelu Zborowskim Słowackiego (1929), prowadził 
od 1929 r. wykłady w Uniwersytecie Stefana Batorego jako docent. Znaczną ich część poświęcił ulubionemu poecie Cyprianowi Norwidowi. Był też autorem licznych artykułów oraz mniejszych przyczynków poświęconych czwartemu wieszczowi. Pisał m.in. o dramatach Norwida („Norwid w szkole dramatycznej” - 1925, „«Kleopatra»” Norwida jako dramat ponadszekspirowski" - 1933), badał stosunek Norwida do innych wielkich romantyków („Norwid o Chopinie” - 1926, „Norwid o Słowackim" - 1927), wykazywał pierwiastki antyromantyczne w jego twórczości („Bezdroża samotnego człowieka” - 1927). Ogłosił wartościowy i aktualny przez wiele lat „Stan badań nad Norwidem oraz postulaty na przyszłość" (1928). W roku 1935 wydał niewielką książkę O gwiaździsty diament Norwida. Recenzował też mnóstwo cudzych prac o Norwidzie. Jako jeden z pierwszych upominał się o wprowadzenie wyboru wierszy Norwida do programu szkolnego („Norwid w kl. 8-ej gimnazjalnej” - 1928). Drugim wysoko cenionym przez Cywińskiego romantykiem był Słowacki. Oprócz wspomnianej habilitacji poświęcił mu m.in. prace: „Symbolika III rapsodu «Króla-Ducha»” (1925), „Słowacki o rewolucji w Rosji” (1925), prekursorską rozprawę „Barokowe tendencje u Słowackiego” (1928). Rzadko sięgał do Mickiewicza (recepcji jego dzieła dotyczy artykuł „Sto lat walki z «Konradem Wallenrodem»" z 1928 r.). Interesował się poezja Władysława Syrokomli („Syrokomla. Człowiek i twórczość” - 1923). Analizował stosunek późniejszych pokoleń do romantyzmu („Walka z romantyzmem” - 1926, „Konwenans romantyczny w literaturze” - 1928). Pracowity, odważny w sądach, nieraz odkrywczych, bezkompromisowy nie potrafil jednak Cywiński zadbać o swój obfity dorobek. „Autor setek pozycji bibliograficznych «rozmywał się» na artykuły drobne, nie koncentrował się na pracach większych, które z trudem w jego dorobku wyławiamy" ${ }^{50}-$ przyznawał Jerzy Starnawski.

Z Uniwersytetem Warszawskim (1922-1932) oraz Uniwersytetem Stefana Batorego (1932-1939) związany był w dwudziestoleciu Manfred Kridl. Romantyzmu dotyczyła jego rozprawa habilitacyjna Antagonizm wieszczóm. Rzeczo stosunku Stowackiego do Mickiewicza (druk w 1925 r.), krzywdząca autora Kordiana. Zasługi filologa widoczne są przede wszystkim w świetnie napisanych wstępach do edycji Dreieł Mickiewicza

\footnotetext{
50 Starnawski 1997b, s. 157.
} 
(2. wydanie z 1929 r.) i Džieł Słowackiego (we współpracy z Leonem Piwińskim - 1930-1931). W serii Biblioteka Narodowa wydał Słowackiego Powieści poetyckie (1921) i Krasińskiego Psalmy praysz̨ości (1928). Rocznicową edycję Pana Tadeusz̧a poprzedził Kridl nowoczesną Pržedmo$w q$, skierowaną w stronę strukturalizmu. $Z$ ważniejszych rozpraw trzeba wymienić dwie: „O lirykach Norwida” (1933) oraz ponad stuczterdziestostronicowa „Poezja polska w latach 1795-1863” (1936).

Konrad Górski, podobnie jak Kridl, najpierw wykładał w Warszawie (1929-1935), a później w Wilnie (1935-1939). Zarówno napisana pod kierunkiem Kleinera praca „Racjonalizm i mistyka Improwizacji Konrada" (wyd. 1922), jak i dysertacja doktorska Poglad na świat młodego Mickienvicza 1815-1823 (druk w 1925 r.) zapowiadały jeden z głównych kierunków badawczych młodego wówczas filologa. Zainteresowanie Mickiewiczem dokumentował on nie tylko artykułami i rozprawami (m.in. „Czym miał być «Pan Tadeusz» dla emigracji” - 1921, „Mickiewicz jako historyk i krytyk literatury czeskiej” - 1926, „«Dziady» drezdeńskie a «Prometeusz» Ajschylosa" - 1934), ale również edycjami opracowanych przez siebie utworów tego poety (m.in. Pana Tadeusza i Konrada Wallenroda).

Polonistykę lubelską w badaniach polskiego romantyzmu reprezentuje do 1939 r. niemal wyłącznie Henryk Życzyński. Absolwent Uniwersytetu Lwowskiego (tam doktorat w 1916 r.) od 1927 r. wykładal w Katolickim Uniwersytecie Lubelskim. Dwie epoki były jego największą naukową pasją: romantyzm i Młoda Polska. Więcej uwagi poświęcił jednak poetom romantycznym. Habilitował się na podstawie zbioru artykułów w książce $Z$ estetyki Mickiewricza (1923). Kolejną książkę Studia estetyczno-literackie (1924) poświęcił wszystkim czterem wieszczom. Do Mickiewicza powracal jeszcze wiele razy: w studium „Rozbiór koncertu Jankiela A. Mickiewicza” (1924), w rozprawie „Kompozycja i styl «Dziadów» wileńskich” (1928), w artykułach „«Dziady» drezdeńskie Mickiewicza w setną rocznicę” (1932), „Mickiewicz w oświetleniu Odyńca” (1934), „Mickiewicz w Odessie. Uwagi w związku z dyskusją zapoczątkowaną przez D. Fiłosofowa” (1934), „Autentyczność ks. Piotra" (1939) - by wymienić tylko ważniejsze prace. Nie szczędził czasu i wysiłku Słowackiemu, przypominając o nim m.in. w publikacjach: „Pojęcie tragizmu u Słowackiego” (1920), „Idea państwowo-twórcza w ujęciu Słowackiego” (1922), „Apolliński i dionizyjski żywioł w poemacie Słowackiego «W Szwajcarii»” (1923), „Słowacki - Wyspiański 
a jutro narodu” (1924), ,J. Słowackiego «Godzina myśli». (Jej geneza i znaczenie w rozwoju twórczości)" (1926). O Krasińskim pamiętał w obszernej rozprawie „Estetyka Zygmunta Krasińskiego” (1920), a o Norwidzie w artykułach „Spór o Norwida” (1935) oraz „Norwida «Zwolon»" (1937). Z poetów pomniejszych zajmował się Kazimierzem Brodzińskim, któremu częściowo poświęcił książkę Brodz̨iński i Mickiewicz, wobec „Laokoona” Lessinga (1922) oraz rozprawy „Charakterystyka poezji K. Brodzińskiego” (1930) i „Brodziński - teoretyk sielanki” (1934). Nie tylko w związku z Mickiewiczem interesował się Antonim Odyńcem, którego Listy zpodró:yy opracowal i wydał w serii Biblioteka Narodowa (1930). W tej samej serii przygotował również edycje Maurycego Mochnackiego O literaturze polskiej w wieku driewietnastym (1923), Mickiewicza Pism estetyczno-krytycznych (1923) oraz we współpracy z Józefem Tretiakiem Grašyny (1924). Odnotował też swój udział w wydaniu sejmowym Driet wszystkich Mickiewicza.

Ludwik Kamykowski, związany na przemian z Krakowem i Lublinem (w 1934 r. uzyskał habilitacje), jako nauczyciel gimnazjalny prowadził badania $z$ historii literatury. Romantyzmu dotyczą dwie duże rozprawy: „«Romantyczność» Mickiewicza” (1926) oraz „Do źródeł mesjanizmu J.P. Woronicza” (1932), a także artykuł „«Ty śpisz Eneaszu». Z dziejów jednego motywu («Podróż do Ziemi Świętej...» Słowackiego)" (1932).

Poloniści związani z Uniwersytetem Poznańskim w latach 1919_ -1939 właściwie nic nie wnieśli do badań polskiego romantyzmu. Zarówno przybyły z Krakowa Tadeusz Grabowski, jak i pozyskany ze Lwowa Stefan Vrtel-Wierczyński zajmowali się przede wszystkim literaturą staropolską. Podzielali takie zainteresowania wykładający tam Roman Pollak i Stanisław Dobrzycki. Ten ostatni wyjątkowo nawiązał do romantyzmu w rocznicowym artykule „Rodowód Telimeny” (1934).

Wyliczając zasługi uczonych różnych uniwersytetów w krzewieniu wiedzy o polskich pisarzach romantycznych, nie sposób przemilczeć roli Tadeusza Boya-Żeleńskiego, mieszkającego w Krakowie, później w Warszawie znakomitego tłumacza, recenzenta i krytyka literackiego oraz teatralnego, który ani nie był filologiem, ani nie związał się zawodowo z żadną uczelnią ${ }^{51}$. Odegrał natomiast istotną rolę jako przeciw-

51 W ostatnich miesiącach życia (od listopada 1939 r. do czerwca 1941 r.) Tadeusz Boy-Żeleński prowadził wykłady z literatury francuskiej w Uniwersytecie Jana Kazi- 
nik idealizacji postaci znanych romantyków, która stanowiła słabość większości ówczesnych monografistów. W książkach Ludzie ṡywi (1929) oraz Brazownicy (1931) obnażał wiele niewygodnych szczegółów przede wszystkim z życia Mickiewicza oraz wyjątkowo tradycjonalistycznie ukazywanego Fredry. Kampania Boya o brązownictwo w nauce o literaturze wywołała jedna z najżywszych dyskusji dwudziestolecia nie tylko w środowisku polonistów.

\section{Zamiast podsumowania}

Skrótowy z konieczności przegląd osiąnnięć polonistyk uniwersyteckich w zakresie badań polskiego romantyzmu do 1939 r. (pełniejszy ich obraz z pewnością rozsadziłby ramy nawet obszernego studium) prowadzi do interesujących wniosków. Do roku 1918 ośrodek lwowski konkurował jedynie z krakowskim. Filolodzy krakowscy napisali w tym czasie co prawda więcej monografii trzech wieszczów, ale były one obarczone biografizmem (postawa poetocentryczna) i nadmiernym subiektywizmem ich autorów. We Lwowie za to powstała najlepsza podówczas monografia Juliusza Kleinera o Krasińskim. Lwów w czasach galicyjskich znacząco też przeważał nad Krakowem pod względem liczby uczonych badających rodzimy romantyzm, w konsekwencji również pod względem liczby publikowanych prac dotyczących tej epoki. Korzystniej wypada polonistyka lwowska od krakowskiej z punktu widzenia metodologii badań literackich. Szkoła krakowska długie lata pozostawała pod przemożnym wpływem konserwatywnego, przede wszystkim ideologicznego stanowiska wobec pisarzy, reprezentowanego przez Stanisława Tarnowskiego i powielanego później przez Józefa Tretiaka, Tadeusza Grabowskiego, częściowo Józefa Kallenbacha, w mniejszym może stopniu Stanisława Windakiewicza. Nie dbając o wartości tekstu dzieła, ferowano subiektywne sądy oceniające przede wszystkim poglądy pisarzy. We Lwowie już w XIX w. Antoni Małecki i Roman Pilat stworzyli lwowską szkołę filologiczną. Daleka była od krakowskiego konserwatyzmu oraz kierowania się ideologicznymi przesłankami w ocenie literatury. Opierała się głównie na językowej i artystycznej analizie tekstu. Odkrywcze na gruncie polskiego literaturoznawstwa ustalenia młodego

mierza (od stycznia 1940 r. Uniwersytecie Iwana Franki) we Lwowie, ale okres drugiej wojny światowej wykracza poza ramy chronologiczne tego artykułu. 
Kleinera przed 1914 r. dotyczace metodologii oraz sformułowane przez niego pojęcie romantyzmu, przejęte później przez innych uczonych, decydująco wpłynęły na sposób badania literatury w dwudziestoleciu międzywojennym.

W latach 1918-1939, kiedy rola Krakowa w badaniach romantyzmu słabła, aktywizowali się filolodzy w kilku innych uniwersytetach. Na tle ich dorobku znowu przodował Lwów i przede wszystkim Juliusz Kleiner ze swoimi znakomitymi, wówczas najlepszymi w Polsce, monografiami o Słowackim i Mickiewiczu. Niedościgłym mistrzem okazał się Kleiner również jako edytor dzieł wielkich romantyków, autor wybitnych opracowań. Kiedy w Wilnie i Krakowie coraz jaśniej świeciła gwiazda Stanisława Pigonia, który stopniowo był uznawany za najlepszego znawcę twórczości Mickiewicza, Kleiner nie ogłosił jeszcze swojej monumentalnej monografii o Mickiewiczu. Jej ukazanie się przypieczętowało prymat lwowianina jako mickiewiczologa. Dzierżył już zresztą palmę pierwszeństwa jako badacz Słowackiego i Krasińskiego. „,W świadomości wykształconych humanistów Kleiner funkcjonuje jako ten, który swoimi badaniami nie tylko zrehabilitował romantyzm, ale wyznaczył mu poczesne miejsce w historii literatury i w nauce w ogóle" ${ }^{52}$ Ale lwowska polonistyka to nie tylko Kleiner. To Edward Kucharski, najlepszy w Polsce znawca Fredry, to Konstanty Wojciechowski i Zygmunt Szweykowski, najwięksi badacze romantycznej powieści (zaniedbanej przez filologów innych środowisk akademickich). Wyjątkowe są też zasługi lwowskich uczonych jako wydawców dzieł romantyków - wielotomowych i kompletnych, ale też pojedynczych, znakomicie opracowanych w serii Biblioteka Narodowa czy w innych popularnych seriach. Przyczyniło się do tego niewattpliwie lwowskie Ossolineum, którego zbiory inspirowały uczonych do pracy i pod którego kopułą odbywały się zebrania Pamiętnika Literackiego, najbardziej zasłużonego czasopisma polonistycznego, organu Towarzystwa Literackiego imienia Adama Mickiewicza, które powstało we Lwowie i tam do roku 1939 znajdowała się jego centrala. Pośród wielu problemów epoki romantyzmu, badanych w dwudziestoleciu, w lwowskim środowisku zabrakło może jedynie większego zainteresowania twórczością Norwida, w poznawaniu którego przodowali wyraźnie literaturoznawcy z Warszawy oraz Stanisław Cywiński z Wilna.

${ }^{52}$ Chrostek 2016, s. 132; Kawyn 1967, s. 50. 
Nie ulega jednak watpliwości, że to lwowscy poloniści najwięcej przyczynili się do poznania tej epoki i jej przedstawicieli w badaniach prowadzonych do roku 1939.

\section{Bibliografia:}

\section{ZBIORY ARCHIWALNE}

Dierżawnyj Archiw Lwiwskoji Obłasti (DALO) fond (dalej: f.) 26, opis (dalej: op.) 5, sprawa (dalej: spr.) 848: druga teczka osobowa Juliusza Kleinera, karta (dalej: k.) 104.

DALO f. 26, op. 5, spr. 1028: teczka osobowa Eugeniusza Kucharskiego, k. 90.

DALO f. 26, op. 7, spr. 903, k. 55-59: Rada Wydziatu Humanistycznego UJK do Ministerstwa WRiOP w sprawie nominacji Eugeniusza Kucharskiego, 21 lipca $1921 r$.

\section{ŹRÓDŁA}

Badecki, Karol 1910: Aleksander Fredro a Zygmunt Krasiński.

Bańkowski, Piotr 1909: Adam Mickiewicz i romantycy warszawscy. (Pierwsze płody poezji romantycznej w świetle krytyki Mickiewicza). Præeglad Narodony, ss. $338-359$

Bańkowski, Piotr 1910: Norwidowe poglądy na sztukę. Przeglad Narodowy, nr 2, ss. 194-215.

Bańkowski, Piotr 1913: Maurycy Mocbnacki jako teoretyk i krytyk romantyzmu polskiego. Kraków

Biegeleisen, Henryk 1884: „Pan Tadeusz” Mickiewicza. Studium estetyczno-literackie. Warszawa.

Biegeleisen, Henryk 1885a: Atak Mickiewicza na obóz klasyków. Dodatek Miesiecrnika Pregeglad Tygodniony, t. 1.

Biegeleisen, Henryk 1885b: Echa walki romantyków z klasykami. Tygodnik Ilustrowany, nr 110-116.

Biegeleisen, Henryk 1885d: Tło ludowe ballady „Ucieczka” A. Mickiewicza. Świt, ss. 75-76, 82-83, 90-91, 99-100, 108-109, 123.

Biegeleisen, Henryk 1885e: Wpływ rodziny na Słowackiego. Muzeum, ss. 169-179, 271-282, 335-344, 445-450.

Biegeleisen, Henryk 1887: Adam Mickiewicz jako rewolucjonista. Ruch, nr 1-3. 


\section{Mariusz Chrostek}

Przełomowe osiągnięcia Iwowskich filologów w badaniach...

Biegeleisen, Henryk 1891a: Motywy ludowe w balladzie Mickiewicza „Lilie”. Wisła 5, ss. 62-103, 393-397.

Bieleleisen, Henryk 1891b: Wrażenia z podróży J. Słowackiego. Biblioteka Warszawska 4, ss. 336-353.

Biegeleisen, Henryk 1892: Z nieznanego pamiętnika A. Fredry. Biblioteka Warszawska 2, ss. 223-247.

Biegeleisen, Henryk 1893: Juliusz Słowacki i Maria Wodzińska. Biblioteka Warszawska 4, ss. 201-220.

Biegeleisen, Henryk 1895a: Juliusz Stowacki, t. 1-2. Lwów.

Biegeleisen, Henryk 1895b: Kobiety w życiu Słowackiego, Præ̨edświt. Dwutygodnik dla kobiet 3(4-9).

Biegeleisen, Henryk 1896: Komedia Nieboska w świetle współczesnej krytyki. Biblioteka Warsqawska 1, ss. 114-150.

Biegeleisen, Henryk 1898: Myśl społeczna „Irydiona”. Stowo Polskie, nr 1.

Biegeleisen, Henryk 1901: Nieznany pamiętnik Wincentego Pola. Świat, ss. 1059-1060, 1092-1095, 1119-1122, 1154-1156, 1182-1183, 1212-1214.

Biegeleisen, Henryk 1906: Nieznany dziennik podróży do Ziemi Świętej J. Słowackiego. Biblioteka Warszawska 4, ss. 466-492.

Biegeleisen, Henryk 1907: Do genezy Nieboskiej. Rocznik Koła Literacko-Artystycznego we Lwowie, ss. 84-128.

Biegeleisen, Henryk 1913: Lirnik mazowiecki. Jego życie $i$ dzieło w swietle nieznanej korespondencji poety. Kraków.

Bluth, Rafał Marceli 1925: Psychogeneza „Snu w Dreźnie”. Przeglad Wspótcresny 13(37), ss. 288-300; 14(39), ss. 97-111.

Blüth, Rafał Marceli 1925/1926: Mickiewicz wobec ruchu literackiego w Rosji w okresie 1826-1829. Pamiętnik Literacki 22/23, ss. 403-417.

Bluth, Rafał Marceli 1927a: Do przyjaciół Moskali. Ruch Literacki 1, ss. 11-15; 2, ss. 39-44.

Bluth, Rafał Marceli 1927b: Mickiewicz i Rylejew pod pomnikiem Piotra Wielkiego. Rocznike Koła Polonistów Stuchaczón Uniwersytetu Warszawskiego, ss. 43-59.

Bluth, Rafał Marceli 1928: Adam Mickiewicz a Teodor Tiutczew. Ruch Literacki nr 6, ss. 163-166.

Bluth, Rafał Marceli 1929: Chrześcijański Prometeusz. Wpływ Boehmego na koncepcję III cz. „Dziadów”. [W:] Z dziejón literatury polskiej XIX wieku. Warszawa: Towarzystwo Naukowe Warszawskie, ss. 178-211. 
Borowy, Wacław 1921: Ze studiów nad Fredrą: O „Pawle i Gawle”; „Trzy po trzy”; Akcja „Zemsty”. Kraków. Z Historii i Literatury, nr 9.

Borowy, Wacław 1922: Zagadkowość w kompozycji „Dziadów” i próba jej wyjaśnienia. Przeglad Współczesny, nr 3, ss. 1-29.

Borowy, Wacław 1925: Nowogródczyzna mickiewiczowska. Ziemia 10/12, ss. 239_ -254 .

Borowy, Wacław 1925: Norwidiana 1921-1924. Pamiętnik Literacki 1924/1924, ss. 474-486.

Borowy, Wacław 1930: Norwidiana 1925-1929. Pamietnik Literacki 1930, ss. 170 -185 .

Borowy, Wacław 1937: Norwidiana 1930-1935. Pamietnik Literacki 1936, ss. 989-1011; 1937, ss. 315-357.

Borowy, Wacław 1936: Spory o Norwida. Życie i Myśl 1952 (7/9), ss. 246-253 [powst. 1936, ale druk 1952].

Boy-Żeleński, Tadeusz 192: Ludżie żymi. Warszawa.

Boy-Żeleński, Tadeusz 1931: Brazownicy. Warszawa.

Bruchnalski, Wilhelm 1889a: „Grażyna”. Według autografu znajdującego się w posiadaniu Konstantego hr. Przezdzieckiego. Pamiętnik Towaraystwa Literackiego im. Adama Mickiewicza, t. 3, ss. 215-256.

Bruchnalski, Wilhelm 1889b: Reminiscencje w „Panu Tadeuszu” z Homera, Wergiliusza i Tassa. Pamiętnik. Towarzystwa Literackiego im. Adama Mickiewicza, R. 2, ss. 95-121.

Bruchnalski, Wilhelm 1889c: Źródła historyczne „Konrada Wallenroda”. Pamiętnik Towarzystwa Literackiego im. Adama Mickiewicza, R. 3, ss. 102-119.

Bruchnalski, Wilhelm 1891a: Mickiewicz a Moore. Przyczynek do genezy „Konrada Wallenroda". Pamietnik Towaryystwa Literackiego im. Adama Mickiewicza, R. 5, ss. 143-164

Bruchnalski, Wilhelm 1891b: Sąd Galicjanina o Mickiewiczu z lat 1822-1824 Pamiętnik Towarzystwa Literackiego im. Adama Mickiewicza, R. 5, ss. 214-219.

Bruchnalski, Wilhelm 1894: Pierwsze utwory Mickiewicza naśladowane w literaturze galicyjskiej 1822-1830. [W:] Sprawozdania z czynności Zakładu Narodowego im. Ossolinskich za r. 1894. Lwów, ss. 45-62.

Bruchnalski, Wilhelm 1898a: Sonety Mickiewicza w literaturze galicyjskiej w latach 1827-1828. Pamiętnik. Towaryystwa Literackiego im. Adama Mickiewicza, ss. 184 $-214$ 


\section{Mariusz Chrostek}

\section{Przełomowe osiągnięcia Iwowskich filologów w badaniach...}

Bruchnalski, Wilhelm 1898b: Z tradycji galicyjskiej o dziełach Mickiewicza. Pamietnik. Towaryystwa Literackiego im. Adama Mickiewicza, ss. 284-288

Bruchnalski, Wilhelm 1907: Mickiewicz - Niemcewicz: Studium historycznoliterackie. 1. Twórczość Mickiewicza do roku 1824. Lwów, ss. 132.

Bruchnalski, Wilhelm 1910: O przyczynki do genezy „Dziadów” wileńskich. Pamiętnike Literacki, ss. 231-250.

Bruchnalski, Wilhelm 1912: Przyczynek do genezy „Upiora” i drugiej części „Dziadów”. Wyimek z większej całości. [W:] Ksiega pamiatkowa ku uczrzeniu 250. Rocznicy założenia Uniwersytetu Lwowskiego, t. 1. Lwów, ss. 1-18.

Bruchnalski, Wilhelm 1925: Mickiewicza „Dziady” wileńskie wobec Chateaubrianda powieści „Atala” i „René”. [W:] Ksiega pamiatkowa ku cz̧ci Oswalda Balzera, t. 1. Lwów, ss. 89-104.

Bruchnalski, Wilhelm 1928: Romeo i Julia” - „Konrad Wallenrod”. Motyw pieśni porannej. [W:] Ksiega pamiatkowa ku uczcreniu 30-letniej pracy nankowej i nauczycielskiej Stanisława Dobrzyckiego. Poznań, ss. 1-17.

Bruchnalski, Wilhelm 1936: Paralele niektóre między „Panem Tadeuszem” a „Męczennikami” Chateaubrianda. [W:] Ksiega pamiqtkowa ku czici Leona Pinińskiego, t. 1. Lwów, ss. 121-131.

Chlebowski, Bronisław 1907: Idea, układ i artyzm „Dziadów” kowieńskich i „Fragmentów” pośmiertnych. Myśl Polska, nr 24-25.

Chlebowski, Bronisław 1908: Słowacki i Szekspir. [W:] Wiek XIX. Sto lat myśli polskiej, t. 4. Warszawa.

Chlebowski, Bronisław 1911: Jak powstawały „Dziady” kowieńskie. Sprawozdania z Posiedzeń Towarzystwa Nankowego Warszawskiego. Wydziat Jezyka i Literatury, R. 4 , z. 4

Chmielowski, Piotr 1873: Kobiety Mickiewicza, Stowackiego i Krasińskiego. Studium literackie. Warszawa, ss. 240.

Chmielowski, Piotr 1876: Zygmunt Kaczkowski. Jego życie i działalność literacka. Niwa, t. 10, nr 45-48, ss. 654-662, 736-756, 821-848, 887-916.

Chmielowski, Piotr 1884: Odczyty Mickiewicza w Lozannie. Wedrowiec, nr 13-27.

Chmielowski, Piotr 1886: Adam Mickiewicz. Zarys biograficzno-literacki, t. 1-2. Warszawa: Wydawnictwo Gebethnera I Wolffa, ss. $466+482$.

Chmielowski, Piotr 1887, 1895: Nasi powieściopisarze. Zarysy literackie. Kraków: Księgarnia J.K. Żupańskiego i K.J. Heumanna.

Chmielowski, Piotr 1888-1898: Estetyczno-krytyczne poglądy Adama Mickiewicza. Pamiętnik. Towaraystwa Literackiego im. Adama Mickiewicza 1888, R. 2, ss. 3-34; 1889, R. 3, ss. 3-40; 1891, R. 5, ss. 3-42; 1898, R. 6, ss. 161-183. 
Chmielowski, Piotr 1890-1892: Józef Korzeniowski. Charakterystyka pisarza i dzieł jego. Tygodnik Ilustrowany 1890, seria V, t. 1; 1891, seria V, t. 4; 1892, seria $\mathrm{V}$, t. 6.

Chmielowski, Piotr 1897-1898: Filozoficzne poglądy Mickiewicza. Przeglad Filozoficzny 1897, ss. 1-43; 1898, ss. 1-71.

Chmielowski, Piotr 1899-1900: Historii literatury polskiej, t. 1-6. Warszawa: Biblioteka Dzieł Wyborowych.

Chmielowski, Piotr 1903a: Album Mickiewicza. Kurier Lwowski, nr 331.

Chmielowski, Piotr 1903b: Kazimierz Brodzinskki. Złoczów: Biblioteka Powszechna.

Chmielowski, Piotr 1903c: Młodość ducha i Mickiewicz. Stowo Polskie, nr 600.

Chrzanowski, Ignacy 1917: O komediach Aleksandra Fredry. Kraków.

Chrzanowski, Ignacy 1918: Z epoki romantyzmu. Studia i szkice. Kraków.

Chrzanowski, Ignacy 1919: „Oda do młodości” na tle epoki. Tygodnik Ilustrowany, nr 1-2.

Chrzanowski, Ignacy 1920: „Przedświt” a prelekcje paryskie. Przeglad Narodowy, nr 3, ss. 354-393.

Chrzanowski, Ignacy 1921: Mickiewicz wobec Kościoła w ostatnim kursie prelekcji paryskich. Przeglad Narodowy, nr 1, ss. 73-103.

Chrzanowski, Ignacy 1922: „Godzina myśli”. (Z wykładów o Słowackim). Præeglad Humanistyczny, ss. 285-297.

Chrzanowski, Ignacy 1924: Czy „Lilla Weneda” jest arcydziełem dramatu? Przeglad Warszawski, nr 36, ss. 263-289.

Chrzanowski, Ignacy 1925: Uwagi nad prologiem „Kordiana”. Sprawozdania Polskiej Akademii Umiejętności, nr 7.

Chrzanowski, Ignacy 1928: Poezja Krasińskiego. Próba syntezy. Pamiętnik Literacki, ss. $10-38,238-251$.

Chrzanowski, Ignacy 1934: Wzniosłość w „Panu Tadeuszu”. Pamiętnik Literacki, ss. 13-28.

Cywiński, Stanisław 1909: O Cyprianie Norwidzie słów kilka. Łan Młodzieży, nr 9-12.

Cywiński, Stanisław 1914a: Ewolucja w literaturze. Kurier Wileński, nr 64, 72.

Cywiński, Stanisław 1914b: Romantyzm a mesjanizm. Towarzystwo Prayjaciót Nauk w Wilnie 1911/1914, t. 5, ss. 238-315.

Cywiński, Stanisław 1923: Syrokomla. Człowiek i twórczość. [W:] W. Syrokomla, Wybórpoezji, t. 1-2. Do druku przygotował, przypisami i posłowiem zaopatrzył S. Cywiński. Wilno. 
Cywiński, Stanisław 1925a: Norwid w szkole dramatycznej. Tygodnik Wileński, nr 1.

Cywiński, Stanisław 1925b: Słowacki o rewolucji w Rosji. Tygodnik Wileński, nr 4, ss. 2-4.

Cywiński, Stanisław 1925c: Psyche - Prometeanka. Symbolika III rapsodu „KrólaDucha”. Tygodnik Wileński, nr 2, ss. 4-5.

Cywiński, Stanisław 1926a: Norwid o Chopinie. Dziennik Wileński, R. 10, nr 263.

Cywiński, Stanisław 1926b: Walka z romantyzmem. Driennik Wileński, z. 2.

Cywiński, Stanisław 1927a: Bezdroża samotnego człowieka. Myśl Narodowa, R. 7, nr 2, ss. 22-25; nr 4, ss. 45-47.

Cywiński, Stanisław 1927b: Norwid o Słowackim. Dziennik Wileński, R. 11, nr 144.

Cywiński, Stanisław 1928a: Barokowe tendencje u Słowackiego. Myśl Narodowa, R. 8, nr 16, ss. 247-249; nr 18, ss. 269-271.

Cywiński, Stanisław 1928b: Konwenans romantyczny w literaturze. Myśl Narodowa, nr 6, ss. 67-69.

Cywiński, Stanisław 1928c: Norwid w kl. 8-ej gimnazjalnej. Przeglad Pedagogiczny, R. 47, nr 26, ss. 641-646.

Cywiński, Stanisław 1928d: Stan badań nad Norwidem oraz postulaty na przyszłość. Ruch Literacki, R. 3, nr 1, ss. 7-13.

Cywiński, Stanisław 1928e: Sto lat walki z „Konradem Wallenrodem”. Źródła Mocy, nr 4, ss. 19-31.

Cywiński, Stanisław 1933: „Kleopatra” Norwida jako dramat ponadszekspirowski. Przeglad Wspótczesny, R. 12, t. 46, ss. 79-94.

Cywiński, Stanisław 1935: O gwiaździsty diament Norwida. Wilno.

Czerny, Zygmunt 1912: Krasiński w literaturze francuskiej. Pamiętnik Literacki, R. 11, ss. 430-453.

Dobrzycki, Stanisław 1934: Rodowód Telimeny. Warszawa: Ultima Thule.

Gostomski, Walery 1894: Arcydzieto poeziji polskiej. A. Mickiewicza „Pan Tadeusz”. Studium krytyczne. Kraków: Księgarnia Spółki Wydawniczej Polskiej.

Górski, Konrad 1921: Czym miał być „Pan Tadeusz” dla emigracji. Przeglad Narodowy, R. 10, nr 2, ss. 191-210; nr 3, ss. 320-346.

Górski, Konrad 1922: Racjonalizm i mistyka Improwizacji Konrada. Przeglad Warszawski, nr 12, ss. 340-361.

Górski, Konrad 1925: Poglad na świat młodego Mickiewicza 1815-1823. Warszawa. Zakłady Drukarskie Wacława Piekarniaka. Drukarz. 
Górski, Konrad 1926: Mickiewicz jako historyk i krytyk literatury czeskiej. Pamiętnik Literacki 1925/1926, ss. 286-316.

Górski, Konrad 1934: „Dziady” drezdeńskie a „Prometeusz” Ajschylosa. [W:] II Międzynarodowy Zjazd Slawistón. Ksiega referatón. Sekcja 2. Warszawa.

Grabowski, Tadeusz 1909-1912: Juliusz. Stowacki. Jego żyot i dzieła na tle wspótczesnej epoki, t. 1-2, Kraków: nakł. autora.

Grabowski, Tadeusz 1912: Zygmunt Krasinski. Jego s̀nwot $i$ dzieła na tle współczesnej epoki. Poznań: nakł. i dr. „Praca”.

Gubrynowicz, Bronisław 1893: Piast Dantyszek. Karta z twórczości poetyckiej J. Słowackiego. Sprawozdanie z. Czynności Zakładu Narodowego im. Ossolinskich za 1893. Lwów, ss. 47-63.

Gubrynowicz, Bronisław 1898: Juliusz Słowacki w świetle najnowszej krytyki. Rec. Ferdynand Hoesick, Życie Juliusza Stowackiego na tle wspótczesnej epoki (1809-1849, t. 1-3). Kraków 1896-1897. Kwartalnik Historyczny, ss. 48-87.

Gubrynowicz, Bronisław 1910: Stan dotychczasowych badań nad Słowackim. [W:] Pamiętnik zjazdu bistorycznoliterackiego im. J. Słowackiego we Lwowie. Lwów: nakł. uczestników Zjazdu, ss. 23-32.

Gubrynowicz, Bronisław 1917: Kazimierz Brodziński. Życie i dzieła. C₹. I. Lwów: Gubrynowicz i Syn.

Hahn, Wiktor 1909a: Cyprian Norwid o Słowackim. Przewodnik Nankowy i Literacki, R. 37, ss. 37-45.

Hahn, Wiktor 1909b: O jyciu i dziełach Juliusza Stowackiego. Brody: nakł. i druk Księgarni F. Westa.

Hahn, Wiktor 1909c: Szkice literackie o Juliusqu Stowackim. Brody: nakł. i druk Księgarni F. Westa.

Hahn, Wiktor 1910a: O tzw. bluszczowatości Słowackiego. [W:] Pamiętnik zjaz̧du historycznoliterackiego im. J. Stowackiego we Lwowie. Lwów: nakł. uczestników Zjazdu, ss. 56-61.

Hahn, Wiktor (red.) 1910b: Pamietnik Zjazdu Historycznoliterackiego im. Juliusza Stowackiego we Lwowie. Lwów: nakł. uczestników Zjazdu.

Hoesick, Ferdynand 1895a: „Anhelli” i „Trzy poematy”. Przyczynki do dziejów twórczości Juliusza Słowackiego. Rozprawy Akademii Umiejetności Wydziału Filologicznego, t. 9, ss. 212-291.

Hoesick, Ferdynand 1895b: O Stowackim, Krasinskim i Mickiewiczu. Studia bistorycznoliterackie. Kraków: G. Gebethner i Spółka, nakł. Autora. 
Hoesick, Ferdynand 1896-1897: Życie Juliusza Stowackiego na tle wspótczesnej epoki (1809-1849). Biografia psychologiczna, t. 1-3. Kraków: G. Gebethner i Spółka.

Hoesick, Ferdynand 1899: Fryderyk Chopin. Zarys biograficzny. Petersburg: nakł. K. Grendyszyńskiego.

Hoesick, Ferdynand 1902-1903a: Nad jeziora wtoskim brzegiem. Wspomnienie z. życia Zygmunta Krasińskiego. Warszawa: nakł. i drukiem M. Arcta.

Hoesick, Ferdynand 1902-1903b: Nad woda wielka i caysta. Z jycia poetów nad Lemanem. Warszawa: nakł. i drukiem M. Arcta.

Hoesick, Ferdynand 1909: Miłość w ṡyciu Zygmunta Krasinskiego. Kraków: Drukarnia Uniwersytetu Jagiellońskiego.

Hoesick, Ferdynand 1918: „Siła fatalna” poezji Słowackiego. Przyczynek do sławy pośmiertnej poety. Præewodnik Naukony i Literacki, z. 1-7.

Jarecki, Kazimierz 1901: Juliusz Słowacki i poemat „W Szwajcarii”. Biblioteka Warsqawska, R. 61, t. 2, ss. 89-117, 317-345.

Jarecki, Kazimierz 1903a: Do genezy „Mazepy”. Biblioteka Warszawska, R. 63, t. 3 , ss. $174-178$.

Jarecki, Kazimierz 1903b: Kiedy powstał „Wacław” Słowackiego?. Pamiętnik Literacki, R. 2, z. 3, ss. 442-445.

Jarecki, Kazimierz 1904a: Idee historiozoficzne Woronicza a mesjanizm polski. Pamietnik Literacki, R. 3, z. 3, ss. 414-427.

Jarecki, Kazimierz 1904b: Słowackiego „Beatrix Cenci”. Biblioteka Warszawska, R. 64, t. 3, ss. 130-165.

Jarecki, Kazimierz 1904c: Śp. Karol Baykowski i towianizm. Stowo Polskie, R. 10, nr 476, 496.

Jarecki, Kazimierz 1909: Testament mój. Kurier Warsqawski, nr 1, s. 16.

Kallenbach, Józef 1897: Adam Mickiewicæ, t. 1-2. Kraków: Spółka Wydawnicza Polska.

Kallenbach, Józef 1904: Zygmunt Krasiński. Życie i twórczosíc lat młodych, t. 1-2. Lwów: Księgarnia Polska B. Połonieckiego.

Kallenbach, Józef 1906: Lata szkolne Zygmunta Krasińskiego. Nowe materiały. Muzeum, t. 2, ss. 345-360.

Kallenbach, Józef 1908: Filologia Adama Mickiewicza. [W:] Stromata in honorem Casimiri Morawski. Kraków, ss. 223-231.

Kallenbach, Józef 1908/1909: Archiwum filomatów. Goniec Wileński 1908, nr 99; 1909, nr 136/137. 
Kallenbach, Józef 1909: O nieznanych utworach młodzieńczych Adama Mickiewicza („Mieszko”, „Pani Aniela”, „Darczanka”, „Kartofla”, „Warcaby”). Pamiętnik Literacki, R. 7 (1908), ss. 75-89, 482-514. Odb. Lwów 1909.

Kallenbach, Józef 1910: Lata uniwersyteckie Adama Mickiewicza (1815-1819). Biblioteka Warszawska, R. 70, t. 1, ss. 228-249, 457-473.

Kallenbach, Józef 1911a: Mickiewicz w Kownie. 1. Pierwszy rok szkolny. Biblioteka Warszawska, t. 1, ss. 68-108.

Kallenbach, Józef 1911b: Tradycja domowa w „Panu Tadeuszu”. Czas, nr 276.

Kallenbach, Józef 1914a: Do genezy „Przedświtu”. Kurier Warszawski, R. 94, nr 1.

Kallenbach, Józef 1914b: Ród filomatów. Na podstawie Archiwum Filomatów. Biblioteka Warsqawska, t. 1, ss. 193-239.

Kallenbach, Józef 1916: „Anhelli” i „Ostatni”. Przeglad Powszechny, t. 130, ss. 172-188 .

Kamykowski, Ludwik 1926: „Romantyczność” Mickiewicza. [W:] Ignacemu Chrz̧anowskiemu uczniowie lubliniacy. Lublin, ss. 43-86.

Kamykowski, Ludwik 1932a: Do źródeł mesjanizmu J.P. Woronicza. Pamiętnik Literacki, R. 29, z. 3/4, ss. 319-348.

Kamykowski, Ludwik 1932b: „Ty śpisz Eneaszu”. Z dziejów jednego motywu („Podróż do Ziemi Świętej...” Słowackiego). Ruch Literacki, R. 7, nr 6, ss. 160-175.

Kasprowicz, Jan 1890: Pojęcia społeczno-polityczne Mickiewicza. Kurier Lwowski, nr 183.

Kasprowicz, Jan 1893: Lirnik mazowiecki. Lwów: Towarzystwo im. S. Staszica we Lwowie

Kasprowicz, Jan 1898a: Pod znakiem Mickiewicza. Kurier Lwowski, nr 1.

Kasprowicz, Jan 1898b: Wieś mazowiecka a poezja Lenartowicza. Tydzień. Dodatek do Kuriera Lwowskiego, nr 24, s. 190.

Kasprowicz, Jan 1899: Słowacki i poezja najnowsza. Goniec Wielkopolski, 1899, nr 293-297; 1900, nr 3-6.

Kasprowicz, Jan 1904: Pod pomnikiem Mickiewicza. Stowo Polskie, R. 9, nr 510.

Kasprowicz, Jan 1905: Liryka Teofila Lenartowicza. Pamiętnik Literacki, R. 4, ss. 149-204.

Kawyn, Stefan 1937: Ideologie stronnictw politycznych wobec Mickiewicza 1890-1898. Lwów: nakł. „Filomaty”. 


\section{Mariusz Chrostek}

\section{Przełomowe osiągnięcia Iwowskich filologów w badaniach...}

Kawyn, Stefan 1938: Cyganeria warszawska. Warszawa. Kasa im. Mianowskiego Instytut Popierania Nauki.

Kleiner, Juliusz 1906a: Bohaterka „Króla-Ducha”. Stowo Polskie, nr 166, ss. 1-2; nr 168, ss. 1-2; nr 170, ss. 1-2.

Kleiner, Juliusz 1906b: Książę Michał Twerski. Czwarte wcielenie Króla-Ducha. Tygodnik Ilustrowany, R. 47, nr 48, ss. 1042-1043.

Kleiner, Juliusz 1912: Zygmunt Krasiński. Drieje myśli, t. 1-2. Lwów: nakł. Towarzystwa Wydawniczego Warszawa - E. Wende i Spółka.

Kleiner, Juliusz 1913: Charakter i przedmiot badań literackich. Biblioteka Warszanska, R. 73 , t. 1, 447-465.

Kleiner, Juliusz 1914: Z Zagadnień metodologii literackiej. Analiza dzieła. Przewodnik Naukowy i Literacki, R. 42, ss. 361-369.

Kleiner, Juliusz 1919-1927: Juliusz Stowacki. Drieje twórczości, t. 1-4. Warszawa: Gebetner i Wolff, Lwów: Zakład Narodowy im. Ossolińskich.

Kleiner, Juliusz 1925: O „Panu Tadeuszu” - książce budującej. Pamiętnik Warszanski, R. 5, t. 1 , nr 42, ss. 259-270.

Kleiner, Juliusz 1928a: Her w zaświatach (Z komentarza rapsodu I „KrólaDucha”). Przeglad Wspótczesny, R. 7, t. 27, nr 79, ss. 205-223.

Kleiner, Juliusz 1928b: Kompozycja „Dziadów” części III. [W:] Księga pamiatkowa ku cz̧ci Stanisława Dobrayckiego. Poznań, ss. 137-144.

Kleiner, Juliusz 1928c: Z badań nad poezją wielkich romantyków. 1. „Grażyna” jako poemat polityczny. 2. Ojciec i syn w „Irydionie”. Tygodnik Ilustrowany, R. 70, nr 52, s. 962. Dostęp online: https://bcul.lib.uni.lodz.pl/dlibra/publication/ 311/edition/180/content.

Kleiner, Juliusz 1929a: Die polnische Literatur. [W:] Handbuch der Literaturwissenschaft, red. Oskar Walzel. Berlin.

Kleiner, Juliusz 1929b: Imię «czterdzieści i cztery» czy nazwanie czterdziestką i czwórka. Ruch Literacki, R. 4, ss. 295-299.

Kleiner, Juliusz 1929c: Mickiewicz na tle literatury światowej. Tygodnik Ilustrowany, R. 71, nr 18, ss. 348-350. Dostęp online: https://bcul.lib.uni.lodz.pl/dlibra/ publication/315/edition/183/content.

Kleiner, Juliusz 1931: Polska mistyka romantyczna wobec koncepcji paralelizmu światów. [W:] Ksiega pamiatkowa Polskiego Towaraystwa Filozoficznego 12 II 1904 12 II 1929. Lwów, ss. 291-301.

Kleiner, Juliusz 1932: Zarys dziejów literatury polskiej, t. 1-2. Lwów: Zakład Narodowy im. Ossolińskich. 
Kleiner, Juliusz 1934a: Mickiewicz, t. 1: Drieje Gustawa. Lwów: Zakład Narodowy im. Ossolińskich.

Kleiner, Juliusz 1934b: Miltonowski motyw bóstw uchodzących w „Królu-Duchu”. Ruch Literacki, R. 9, nr 4, ss. 108-109.

Kleiner, Juliusz 1935: Mickiewicz et son épopée nationale. Revue bimensuelle des cours et conférences, R. 36, nr 11, ss. 103-205.

Kleiner, Juliusz 1938: Stowacki. Lwów: Państwowe Wydawnictwo Książek Szkolnych

Kleiner, Juliusz 1948-1949: Mickiewicz, t. 2: Dzieje Konrada. Lublin: Towarzystwo Naukowe Katolickiego Uniwersytetu Lubelskiego.

Kolbuszewski, Kazimierz 1909a: Czasy barskie w poezji Słowackiego. [W:] Ksiega pamiatkowa ku uczrzeniu setnej rocznicy urodzin Juliusza Stowackiego, t. 2. Lwów, ss. 3-43 [oddzielna paginacja].

Kolbuszewski, Kazimierz 1909b: Ludwika Śniadecka w rzeczywistości i w poezji Słowackiego. [W:] Ksiega pamiatkowa ku ucžz̧eniu setnej rocznicy urodzin Juliusza Stowackiego, t. 2. Lwów, ss. 1-24 [oddzielna paginacja].

Kolbuszewski, Kazimierz 1912a: Napoleonizm w twórczości Krasińskiego. [W:] Ksiega pamiatkowa ku uczereniu setnej rocznicy urodzin Zygmunta Krasińskiego, t. 2. Lwów: Gubrynowicz i Syn, ss. 3-23 [oddzielna paginacja].

Kolbuszewski, Kazimierz 1912b: Zygmunta Krasińskiego twórczość w stosunku do literatury niemieckiej. [W:] Ksiega pamiatkowa ku uczczeniu setnej rocznicy urodzin Zygmunta Krasinskiego, t. 2. Lwów: Gubrynowicz i Syn, ss. 3-73 [oddzielna paginacja].

Kolbuszewski, Kazimierz 1913: Książę Józef w powieści polskiej. Kronika Powszechna, R. 4, nr 43, ss. 715-716.

Kołaczkowski, Stefan 1934: Dwa studia. Fredro-Norwid. Warszawa: Wydawnictwo Droga.

Kowalski, Jerzy 1926a: Czy zginie dla Polski? O wykładach lozańskich Mickiewicza. Ruch Literacki, R. 1, nr 3, ss. 68-75.

Kowalski, Jerzy 1926b : Note sur la première édition monographique des leçons de Mickiewicz à Lausanne. Bulletin de l'Académie Polonaise des Sciences et des Lettres, t. 31, ss. 90-93.

Kowalski, Jerzy 1927 : Adam Mickiewicz à Lausanne (1839-1840). Eos, R. 30, ss. $417-427$

Kridl, Manfred 1909a: Mickiewicz i Lamennais. Studium porównawcz̧e. Warszawa: E. Wende, T. Hiż i A. Turkuł. 
Kridl, Manfred 1909b: Walka Słowackiego z Mickiewiczem. (Próba uzasadnienia końcowego ustępu V pieśni „Beniowskiego”) . [W:] Cieniom Juliusza S towackiego. Lwów: Księgarnia i Skład Nut Gubrynowicza i Schmidta.

Kridl, Manfred 1910a: Mickiewicz w świetle nieznanych pism. Sprawozdania Towarzystwa Naukowego Warszawskiego. Wydział Jezykoznawstwa i Literatury, z. 6, s. $25-72$.

Kridl, Manfred 1910b: Z dziejów stosunku Słowackiego do Mickiewicza. Streszczenie. Sprawozdania Towaryystwa Naukowego Warszawskiego. Wydział Jezykoznawstwa $i$ Literatury, z. 6, ss. 25-72.

Kridl, Manfred 1911: Ustęp z „Kursu literatury polskiej w. XIX”. Wychowanie w Domu i Szkole, z. 4, ss. 344-360; z. 5, ss. 463-473.

Kridl, Manfred 1925: Antagonizm wiesz̨zóm. Rzeczo stosunku Stowackiego do Mickiewicz̧a. Warszawa: Wydawnictwo M. Arcta.

Kridl, Manfred 1933: O lirykach Norwida. Droga, R. 12, nr 11, ss. 1135-1143.

Kridl, Manfred 1936: Poezja polska w latach 1795-1863. [W:] Drieje literatury pięknej w Polsce (PAU. Encyklopedia Polski), cz. 2, wyd. 2. Kraków, ss. 1-44.

Krzyżanowski, Julian 1923: Masynissa i jego rola w „Irydionie”. Przeglad Humanistyczny, z. 2, ss. 176-202.

Krzyżanowski, Julian 1928: Mickiewicz and Pushkin. The Slavonic Review. Londyn, nr 18, ss. 635-645.

Krzyżanowski, Julian 1939: Zagadka „Jermoły” (Kraszewski i George Eliot). [W:] Ksiega ku czci Józefa Ignacego Kraszewskiego. Luck, ss. 141-159.

Kucharski, Eugeniusz 1909a: Strofy osobiste w „Beniowskim”. I. Geneza. [W:] Ksiega pamiatkowa ku uczrzeniu setnej rocznicy urodzin Juliusza Stowackiego, t. 3. Lwów, ss. 3-27 [oddzielna paginacja].

Kucharski, Eugeniusz 1909b: U źródeł duszy” (Słowackiego „Genezis z Ducha”). Kurier Stanisławski, nr 1258; Stowo Polskie, R. 14, nr 425, ss. 7.

Kucharski, Eugeniusz 1911: Romantyzm w komediach Fredry. Biblioteka Warsqawska, t. 1, ss. 252-307.

Kucharski, Eugeniusz 1912: Do genezy „Snu” w I części „Nie-Boskiej” Zygmunta Krasińskiego. Pamiętnike Literacki, R. 11, ss. 157-174.

Kucharski, Eugeniusz 1919: „Wychowanka” Fredry a Goldoniego „La Pamela” i „Pamela maritata”. Przewodnik. Nankony i Literacki, R. 47, ss. 585-604.

Kucharski, Eugeniusz 1920a: Glosy do „Kordiana”. Tygodnik Ilustrowany, R. 67, t. 2 , nr 50, ss. 923; nr 52, ss. 959-960. 
Kucharski, Eugeniusz 1920b: Źródła i podstawy niektórych pomysłów i wątków fredrowskich. Pamiętnik Literacki 1920, R. 17/18, ss. 38-55; 1921, R. 19, ss. 76-106.

Kucharski, Eugeniusz 1921a: Fredro a komedia obca. Stosunek do komedii wtoskiej. Kraków: Krakowska Spółka wydawnicza.

Kucharski, Eugeniusz 1921b: Jabłoń z gwiazd w „Anhellim”. Præeglad Warszawski, R. 1, t. 1, nr 1, ss. 39-51.

Kucharski, Eugeniusz 1921c: O narodowości Geldhaba. Rz̧eczpospolita, nr 189-190.

Kucharski, Eugeniusz 1922: Epoka Fredry i jej wizerunek w komedii 1815-1848. Przeglad Warsqawski, R. 2, t. 1, nr 4, 185-201.

Kucharski, Eugeniusz 1923a: Chronologia komedyj i niektórych pomniejszych utworów Al. Fredry. Rozprawy Wydziału Filologicznego PAU, t. 61, nr 3.

Kucharski, Eugeniusz 1923b: Kilka uwag o życiu i pismach A. Malczewskiego. Pamiętnik Literacki, R. 20, ss. 289-306.

Kucharski, Eugeniusz 1926: Milczenie Fredry. Stowo Polskie, nr 198.

Lubicz-Zaleski, Zygmunt 1910: Kobieta i kobiecość w poezji J. Słowackiego. Przeglad Narodowy, z. 7-9, ss. 88-104, 226-236, 315-348.

Lubicz-Zaleski, Zygmunt 1912: Zygmunt Krasinski. O dziełach $i$ życiu poety w setna rocznice urodżin. Warszawa: Wydawnictwo im. Mieczysława Brzezińskiego.

Lubicz-Zaleski, Zygmunt 1913: Stosunki A. Mickiewicza z E. Quinetem wg nieznanych świadectw i listów. Sprawozdania Towarzystwa Naukowego Warszanskiego, z. 2, ss. 23-26.

Lubicz-Zaleski, Zygmunt 1927: Jules Słowacki, l'Ouvrier de Dieu. Mercure de France (Paryż), nr 695.

Lubicz-Zaleski, Zygmunt 1928: Michelet, Mickiewicz et la Pologne. Revue de Littérature Comparée (Paryż), nr 3, ss. 433-488.

Lubicz-Zaleski, Zygmunt 1929: Adam Mickiewicz, poéte et dictateur moral de Pologne. Revue de Paris, nr 9, ss. 176-189.

Lubicz-Zaleski, Zygmunt 1936: Wartości żywe mesjanizmu polskiego. [W:] Prace historycznoliterackie ku cźci Ignacego Chrzanowskiego. Kraków, ss. 444-455.

Łempicki, Stanisław 1925: Miłość dantejska w poemacie „W Szwajcarii”. Pamiętnik Literacki 1924/1925, R. 21, ss. 155-182.

Lempicki, Stanisław 1926: Przyjaciel Horsztyńskiego. Stowo Polskie, R. 31, nr 72, s. $6 ; \mathrm{nr} 73$, s. $6 ; \mathrm{nr} 76$, s. 6 .

Lempicki, Stanisław 1928a: Nowa interpretacja sonetu Mickiewicza „Ajudah”. Sprawozdania Towarzystwa Nankowego we Lwowie, z. 2, ss. 67-98. 


\section{Mariusz Chrostek}

\section{Przełomowe osiągnięcia Iwowskich filologów w badaniach...}

Łempicki, Stanisław 1928b: Wigilie Słowackiego. Stowo Polskie, R. 33, nr 356, s. 12.

Łempicki, Stanisław 1929: Nieznany najdawniejszy przekład „Dziadów” wileńskich na język niemiecki. Pamiętnik Literacki, R. 20, ss. 194-213.

Łempicki, Stanisław 1934a: „Glosy do „Pana Tadeusza”. Pamietnik Literacki, R. 31, ss. $113-127,408-446$.

Lempicki, Stanisław 1934b: O „Panu Tadeuszu” w stulecie ukarania sie arcydzieła. Lwów: nakładem Macierzy Polskiej.

Makowiecki, Tadeusz 1927: Młodzieńcze poglądy Norwida na sztukę. Pamiętnik Literacki, R. 24, ss. 24-85.

Makowiecki, Tadeusz 1928a: „Promethidion” Norwida a „Dworzanin” Górnickiego. Pamietnik Literacki, R. 3, nr 2, ss. 40-55.

Makowiecki, Tadeusz 1928b: T.T. Jeż a Norwid. Pamiętnik Literacki, R. 3, nr 8, ss. $254-255$.

Makowiecki, Tadeusz 1929a: Listy Cypriana Norwida z roku 1863. Pamiętnik Literacki, R. 26, R. 26, z. 4, ss. 680-724.

Makowiecki, Tadeusz 1929b: Norwid wobec powstania styczniowego. Pamiętnik Literacki, R. 26, z. 4, ss. 564-581.

Makowiecki, Tadeusz 1935/1936: Z batalii o Norwida. Marchołt 1935/1936, R. 2 , z. 2, ss. 331-339.

Małecki, Antoni 1866-1867: Juliusz S towacki. Jego jycie i dzieła w stosunku do wspótczesnej epoki, t. 1-2. Lwów: Zakład Narodowy im. Ossolińskich, nakładem autora.

Matuszewski, Ignacy 1902: Stowacki i nowa sztuka. Warszawa: Gebethner i Wolff.

Pawlikowski, Jan Gwalbert 1899: O mistycyzmie Słowackiego. Przeglad Polityczny, Spoteczny i Literacki, nr 119, 120.

Pawlikowski, Jan Gwalbert 1904: Ze studiów nad „Królem-Duchem”. Popiel. Stowo Polskie, R. 9, nr 68, ss. 1-2; nr 70, ss. 1-2; nr 72, ss. 1-2; nr 79, ss. 1-2; nr 81 , ss. $1-2$.

Pawlikowski, Jan Gwalbert 1906: Z komentarzy do „Króla-Ducha”. Sen anhelliczny Mieczysława o dwunastu aniołach. Pamiętnik Literacki, R. 5, ss. 464-472.

Pawlikowski, Jan Gwalbert 1909: Studiów nad «Królem-Duchem» č. I. Mistyka Stowackiego. Lwów: nakł. księgarni H. Altenberga.

Pawlikowski, Jan Gwalbert 1921: O układzie dialogów genezyjskich Słowackiego. Pamietnik Literacki, R. 19, ss. 64-75.

Pawlikowski, Jan Gwalbert 1922: Z genezy kompozycji „Króla-Ducha” („KrólDuch” a „Beniowski”). Sprawozdania Towarzystwa Naukowego we Lwowie, R. 2, nr 1, ss. 3-8. 
Pawlikowski, Jan Gwalbert 1927: Chronologia pism genezyjskich i rozwój genezyjskich pomysłów Słowackiego. Pamiętnik Literacki 1927, R. 24, z. 3-4, ss. 265-290; 1928 , R. 25, z. 4, s. 523-537.

Pawlikowski, Jan Gwalbert 1928: Na marginesie pism genezyjskich Słowackiego (Zawartość przyrodnicza „Genezis z Ducha”). Rozprawy Towarzystwa Naukowego we Lwowie, R. 28, nr 2.

Pawlikowski, Jan Gwalbert 1930: Społeczno-polityczne idee Słowackiego w dobie mistycyzmu. Mý́l Narodowa, R. 10, nr 28, ss. 434-437; nr 29, ss. 449-452; nr 30, ss. 465-469; nr 31, ss. 479-483; nr 32, ss. 499-501; nr 33, ss. 513-517.

Pawlikowski, Jan Gwalbert 1932: O tzw. „Teogonii” Juliusza Słowackiego. Pamiętnik Literacki, R. 29, ss. 423-448.

Pawlikowski, Jan Gwalbert 1938: O potrzebie krytycznego wydania pism genezyjskich Słowackiego. Sprawozdania Poznańskiego Towaryystwa Prayjaciół Nauk, nr 2, ss. 74-78.

Petzold, Emil 1902a: Motywy Mickiewiczowskie. Pamiętnik Literacki 1902, R. 1, ss. 632-634; 1903, R. 2, ss. 71-83, 618-621.

Petzold, Emil 1902b: Przyczynek do genezy „Romantyczności” Mickiewicza. Pamietnik Literacki, R. 1, ss. 446-448.

Petzold, Emil 1905: O „Czatach” Mickiewicza. Sprawozdania Gimnazjum IV we Lwowie, ss. 3-18.

Petzold, Emil 1906: Reminiscencje z Tiecka w „Dziadach”. Sprawozdania Gimnazjum IV we Lwowie, ss. 3-14.

Petzold, Emil 1910: Ballada Mickiewicza a Goethego. Przewodnik Naukowy i Literacki, R. 38, ss. 289-304, 385-400, 481-495.

Pigoń, Stanisław 1911: O „Ksiegach narodu i pielgrzymstwa polskiego” A. Mickiewicza. Warszawa: Gebethner i Wolff.

Pigoń, Stanisław 1920: Idee St. Martina w „Księgach narodu i pielgrzymstwa”. Preglad Narodowy, nr 6, ss. 917-940.

Pigoń, Stanisław 1921a: Cela Konrada. Przyczynek do topografii „Dziadów” części III. Rzeczpospolita, nr 127-132.

Pigoń, Stanisław 1921b: Z niedrukowanej korespondencji Norwida. Kurier Poznański, nr 33.

Pigoń, Stanisław 1922: „Z epoki Mickiewicza”. Studia i sұkeice. Lwów: Wydawnictwo Zakładu Narodowego im. Ossolińskich.

Pigoń, Stanisław 1924: Gtosy sprzed wieku. Szkice z dziejów procesu filareckiego. Wilno: Wydawnictwo Księgarni Stowarzyszenia Nauczycielstwa Polskiego. 
Pigoń, Stanisław 1925a: Norwid o „Panu Tadeuszu”. Głos Narodu, nr 171.

Pigoń, Stanisław 1925b: S. Goszczyńskiego nieznana powieść poetycka o Wernyhorze. Przeglad Wspótczesny, t. 13, ss. 213-223.

Pigoń, Stanisław 1926: Adoracja Towiańskiego. Przeglad Wspótczesny, t. 16, ss. 213 $-230,353-368$.

Pigoń, Stanisław 1927: Uwagi o prologu „Kordiana”. Præeglad Wspótcæesny, t. 20, ss. 96-107.

Pigoń, Stanisław 1928a: S. Goszczyński w sporze z kołem „Sprawy”. Kartka z dziejów towianizmu. Przeglad Wspótczesny, t. 25, ss. 23-38, 245-269.

Pigoń, Stanisław 1928b: Ze studión nad tekstem „Pana Tadeusza”. Tray notatki. Kraków.

Pigoń, Stanisław 1929a: Uwagi o genezie i zakroju „Kościeliska” S. Goszczyńskiego. Pamiętnik Literacki, ss. 23-43.

Pigoń, Stanisław 1929b: Z dawnego Wilna. Szkice obyczajowe i literackie. Wilno: Wydawnictwo Magistratu Miasta Wilna.

Pigoń, Stanisław 1930: Do źródet „Dziadów” wileńsko-kowieńskich. Wilno: Biblioteka „Źródeł Mocy” nr 3.

Pigoń, Stanisław 1932a: Adam Mickiewicz, w Kole Sprawy Bożej. Warszawa.

Pigoń, Stanisław 1932b: Towiański na Litwie. Przeglad Współczesny, t. 42, ss. 66-77.

Pigoń, Stanisław 1934a: „Pan Tadeusz”. W zrost, wielkosíc i sława. Warszawa: Skład Główny w Kasie im. Mianowskiego.

Pigoń, Stanisław 1934b: Sąd nad Polską w Panu Tadeuszu”. Rocznik Polskiej Akademii Umiejetności 1933/1934, ss. 118-139.

Pigoń, Stanisław 1936a: Na wyżynach romantyzmu. Studia historycznoliterackie. Kraków: Kasa im. Mianowskiego.

Pigoń, Stanisław 1936b: Oratorium wieszcze S. Goszczyńskiego. [W:] Prace bistorycznoliterackie. Ksiega zbiorowa ku czi Ignacego Chrzanowskiego. Kraków, ss. 411-443.

Pigoń, Stanisław 1937: Krasiński w „Zwolonie” Norwida. Myśl Narodowa, nr 6-8.

Pigoń, Stanisław 1947: Z Komborni w śmiat. Kraków: Spółdzielnia Wydawnicza „Wieś”

Pigoń, Stanisław 1960: Zawsze o Nim. Kraków: Wydawnictwo Literackie.

Pilat, Roman 1888: Geneza „Farysa”. Pamietnik Towarzystwa Literackiego im. Adama Mickiewicza, R. 2, ss. 125-134. 
Pilat, Roman 1889: Głosy publicystyki emigracyjnej o pierwszych wykładach Mickiewicza w Collège de France. Pamiętnik. Towaràystwa Literackiego im. Adama Mickiewicza, R. 3, ss. 67-101.

Pilat, Roman 1890a: Nieznana rozprawka Mickiewicza o Karpińskim. Pamiętnik Towaraystwa Literackiego im. Adama Mickiewicza, R. 4, ss. 173-185.

Pilat, Roman 1890b: Opis „matecznika” w trzech redakcjach. Pamiętnik Towarzystwa Literackiego im. Adama Mickiewicza, R. 4, ss. 154-168.

Pilat, Roman 1891: Autografy pierwszych trzech ksiag „Pana Tadeusza”. Pamiętnik Towarzystwa Literackiego im. Adama Mickiewicza, R. 5, ss. 75-140.

Pilat, Roman 1899: Opis gry Wojskiego w „Panu Tadeuszu” według autografu. [W:] Rok Mickiewiczowski. Ksiega pamiatkowa, t. 2. Lwów: księgarnia H. Altenberga, ss. $278-283$

Pini, Tadeusz 1895: Zygmunta Krasińskiego tak zwany „Niedokończony poemat”. Przewodnik. Nankowy i Literacki, ss. 1016-1031, 1091-1112.

Pini, Tadeusz 1898a: Mickiewicz jako wydawca poezji Garczyńskiego. Pamiętnik Towaryystwa Literackiego im. Adama Mickiewicza, R. 6, ss. 435-480.

Pini, Tadeusz 1898b: Stefan Garczyński. Szkic biograficzno-literacki. Przewodnik Nankowy i Literacki, ss. 463-483, 573-593, 676-696.

Pini, Tadeusz 1899a: Garczyński i Krasiński. Szkic literacki. Sprawozdanie Dyrekeji c.k. Lwowskiego Gimnazjum im. Franciszka Józefa za rok 1900, ss. 3-31.

Pini, Tadeusz 1899b: Studium nad geneza „Irydiona” Zygmunta Krasińskiego. Kwartalnik Historyczny, z. 3, rozdz. 2.

Pini, Tadeusz 1901: Władystaw Syrokomla i jego utwory. Lwów: Biblioteka Macierzy Polskiej nr 10.

Pini, Tadeusz 1928: Krasinski. Życie i twórczosíc. Poznań: Wydawnictwo Polskie R. Wegner

Pini, Tadeusz 1933: „Dziady” a Maryla. Pamiętnik Literacki, R. 30, z. 2.

Porębowicz, Edward 1893: Urywek pierwszego brulionu „Pana Tadeusza”. Świat, R. 6 , nr 12, ss. 265-267.

Porębowicz, Edward 1896: Jeszcze „Beatrix Cenci”. Ateneum, t. 2, ss. 466-471.

Porębowicz, Edward 1898a: Gdzie jest źródło wiary Mickiewicza w godność prorocza poety?. Pamietnik Towaraystwa Literackiego im. Adama Mickiewicza, R. 6, ss. 310-315.

Porębowicz, Edward 1898b: Przyczynek do pojęcia „romantyczność” u Mickiewicza. Pamiętnik Towaryystwa Literackiego im. Adama Mickiewicza, R. 6, 276-280. 
Porębowicz, Edward 1898c: Słówko o motywie ballady „Powrót taty”. Pamiętnik Towaryystwa Literackiego im. Adama Mickiewicza, R. 6, 288-290.

Porębowicz, Edward 1900: Triady Zygmunta Krasińskiego. [W:] Ksiega pamiqtkowa Uniwersytetu Lwowskiego ku uczczeniu pię́setnej rocznicy fundacji jagiellonskiej Uniwersytetu Krakowskiego. Lwów: Senat Uniwersytetu Lwowskiego, ss. 1-34 [osobna paginacja].

Porębowicz, Edward 1917: Glosa do „Genezis z Ducha”. Zdrój, t. 1, z. 5, ss. 132-135 .

Skulski, Ryszard 1934a: „Pan Tadeusz” jako ksiał̌ka sæłkolna. Lwów: Okręg lwowski Towarzystwa Nauczycieli Szkół Średnich i Wyższych.

Skulski, Ryszard 1934b: Pierwsze ślady recepcji Mickiewicza w szkole polskiej. Pamietnik Literacki, R. 31, ss. 446-463.

Skwarczyńska, Stefania 1925a: Ewolucja obrazón u Stowackiego. Lwów. Zakład Narodowy im. Ossolińskich.

Skwarczyńska, Stefania 1925b: Przyczynek do badań nad mistyką Słowackiego. Pamiętnik. Literacki 1925/1926, R. 22/23, ss. 460-467.

Skwarczyńska, Stefania 1930: „Genezis z Ducha” Słowackiego wobec „Confessiones” św. Augustyna. Pamiętnik Literacki, ss. 114-121.

Skwarczyńska, Stefania 1932a: Słowacki i Chateaubriand. Ruch Literacki, nr 4.

Skwarczyńska, Stefania 1932b: Wartość treściowa kolorów w romantyzmie a dzisiaj na tle badania relacji między twórcą a odbiorca. Pamiętnik Literacki, R. 29, z. $3 / 4$.

Skwarczyńska, Stefania 1934: Rozwój watków i obrazów w twórczości Mickiewicza. Lwów: nakładem Przegladu Humanistycznego.

Skwarczyńska, Stefania 1939: Struktura tragizmu „W Szwajcarii” Słowackiego. Prace Polonistyczne, S. 3, ss. 89-129.

Szmydtowa, Zofia 1918: Lenartowicz w wykładzie szkolnym. Præeglad Pedagogiczny, R. 37 , nr $7 / 8$, ss. $402-421$.

Szmydtowa, Zofia 1919: Idea wyzwolenia narodu w „Wallenrodzie”. Pochodnia, nr 3, ss. 148-159.

Szmydtowa, Zofia 1920: Bajka o chłopie i żmii w opracowaniu Mickiewicza. Pamiętnik. Literacki, R. 17/18, ss. 142-148.

Szmydtowa, Zofia 1922: Teofil Lenartowicz. W setną rocznicę urodzin. Przeglad Warszawski, t. 2, nr 8, ss. 163-179.

Szmydtowa, Zofia 1923: Norwida przekład ody Horacego „Ad Pompeium”. Pamietnik Literacki, ss. 109-125. 
Szmydtowa, Zofia 1925a: Norwid a Kochanowski. Blusz̨r, R. 58, nr 16.

Szmydtowa, Zofia 1925b: Norwid wobec tradycji literackiej. Sprawozdania Gimnazjum Żeńskiego im. C. Plater-Zyberkówny, ss. 77-111.

Szmydtowa, Zofia 1929a: Dante a romantyzm polski. [Dante and Polish Romanticism]. The Slavonic and East European Review, t. 8, nr 23, ss. 292-304.

Szmydtowa, Zofia 1929b: Norwid jako tłumacz Homera. [W:] Z dziejón literatury polskiej XIX wieku. Warszawa: Towarzystwo Naukowe Warszawskie, ss. 99-115.

Szmydtowa, Zofia 1933: „Dziady” wileńskie w świetle dialogów Platona. Præeglad Humanistyczny, ss. 203-216.

Szmydtowa, Zofia 1934a: Mazowsze w poezji Lenartowicza. Ziemia, R. 24, nr 10, ss. 248-252.

Szmydtowa, Zofia 1934b: Osobowość Mickiewicza. Marchołt 1934/1935, nr 4, ss. $26-33$.

Szmydtowa, Zofia 1935: Twórczość dramatyczna Norwida. Pamiętnik Literacki, ss. 199-208.

Szmydtowa, Zofia 1936: Platon w twórczości Norwida. Prace bistorycznoliterackie. Ksiega zbiorowa ku czci Ignacego Chrzanowskiego. Kraków, ss. 365-386.

Szmydtowa, Zofia 1938: Nowele Norwida. Przeglad Wspótczesny, nr 8/9, ss. 80-97.

Szpotański, Stanisław 1910: Maurycy Mochnacki. Kraków: Akademia Umiejętności.

Szpotański, Stanisław 1921-1923: Adam Mickiewicz i jego epoka, t. 1-3. Warszawa: Towarzystwo Wydawnicze.

Szyjkowski, Marian 1935a: Kazimierz Brodziński w Czechach. Slavia Occidentalis, t. 14 , ss. $1-44$.

Szyjkowski, Marian 1935b: Mickiewicz jedzie do Pragi. Pamietnik Literacki, z. 3/4, ss. 440-480.

Szyjkowski, Marian 1935c: Wileńscy filomaci w Pradze. Pamiętnik Literacki, z. 1/2, ss. 209-223.

Szyjkowski, Marian 1936: Polskie peregrynacje do Pragi i Karlowych Waróm. Od Augusta Mocnego do Adama Mickiewicza. Warszawa: Instytut Wydawniczy Biblioteka Polska.

Szyjkowski, Marian 1939: Pierwsza recepcja Mickiewicza w czeskiej literaturze. (Zagadnienie ballady). Sprawozdania Polskiej Akademii Umiejetności, t. 44, nr 2, ss. 54-56.

Tarnowski, Stanisław 1867: Profesora Małeckiego ,Juliusz Słowacki”. Przeglad Polski, R. 2, t. 2, 3-55, 218-285, 381-430. 


\section{Mariusz Chrostek}

\section{Przełomowe osiągnięcia Iwowskich filologów w badaniach...}

Tarnowski, Stanisław 1876: Komedie Aleksandra Fredry. Biblioteka Warszanska, t. 2, ss. 249-260, 437-455; t. 3, ss. 1-18.

Tarnowski, Stanisław 1887: Henryk Rzemuski: zodczytów publicznych odbytych we Lwowie w roku 1887. Lwów: Księgarnia Seyfartha i Czajkowskiego.

Tarnowski, Stanisław 1895-1896: Studia do bistorii literatury polskiej. Wiek XIX. Rozprawy i sprawozdania, t. 1-4. Kraków: nakładem Księgarni Spółki Wydawniczej Polskiej.

Tarnowski, Stanisław 1903: Cayśsiec Stowackiego. Wiedeń: nakładem Manza cesarskiej i królewskiej nadwornej i uniwersyteckiej księgarni.

Tarnowski, Stanisław 1905: Mickiewicz Adam. „Pan Tadeusz”. Uwagi. Brody: F. West, Arcydzieła Polskich i Obcych Pisarzy, t. 35.

Tretiak, Józef 1884: Mickiewicz, w Wilnie i Kownie. Życie i poęja, t. 1-3. Lwów: Gubrynowicz i Schmidt.

Tretiak, Józef 1893: Kornel Ujejski i jego poezja. Czas, nr 218-220; Gazeta Lwowska, nr 218-220.

Tretiak, Józef 1896: Szkice literackie. Seria I. Kraków: Spółka Wydawnicza Polska.

Tretiak, Józef 1898: Mtodość Mickiewicza (1798-1824). Życie i poezja, t. 1-2. Petersburg: księgarnia K. Grendyszyńskiego.

Tretiak, Józef 1904: Juliusz Stowacki. Kraków: Akademia Umiejętności

Tretiak, Józef 1906: Mickiewicz i Puszkin. Studia i sұkice. Warszawa: E. Wende i Spółka.

Tretiak, Józef 1911-1914: Bohdan Zaleski, t. 1-2. Kraków: nakładem Akademii Umiejętności, księgarnia Spółki Wydawniczej Polskiej.

Tyszyński, Aleksander 1871: Dwie Świtezianki, czyli rzut oka na ostatni okres poezji polskiej. Biblioteka Warszawska 1870, t. 2, ss. 1-30 [odb. 1871. Warszawa].

Tyszyński, Aleksander 1875: Wiz̨erunki polskie. Zbiór słkiców literackich. Warszawa: nakład i druk S. Lewentala.

Tyszyński, Aleksander 1877: Józef Ignacy Kraszewski i jego powieści historyczne. Ateneum, R. 2, t. 3, s. 1-21.

Ujejski, Józef 1909: Juliusza Słowackiego „Kordian”. Sprawozdania Gimnazjum sw. Jacka w Krakowie, ss. 1-63.

Ujejski, Józef 1915: Ogólny rzut oka na prądy religijno-społeczne wśród emigracji po r. 1831. Sprawozdania Akademii Umiejetności, nr 4, ss. 2-13.

Ujejski, Józef 1916: Gtówne idee w „Anhellim” Stowackiego. Kraków: nakładem Akademii Umiejętności 
Ujejski, Józef 1921: Antoni Malczewski. Poeta i poemat. Warszawa: Trzaska, Evert i Michalski.

Ujejski, Józef 1923: Byronizm i skottyzm w „Konradzie Wallenrodzie”. Kraków: Krakowska Spółka Wydawnicza.

Ujejski, Józef 1924: Król Nowego Izraela. Kartka z dziejów mistyki wieku ó́wieconego. Warszawa: Kasa im. J. Mianowskiego: Instytut Popierania Polskiej twórczości Naukowej.

Ujejski, Józef 1925: O cene absolutu. Rzecz. o Hoene-Wrońskim. Warszawa: Gebethner i Wolff.

Ujejski, Józef 1927: Słowacki jako poeta dumy. Przemówienie na Akademii zorganizowanej w Warszawie dla uczczenia uroczystości sprowadzenia zwłok Juliusza Słowackiego z Paryża przez Warszawę do Krakowa na Wawel w roku 1927. Warszawa [druk ulotny].

Ujejski, Józef 1931: Dzieje polskiego mesjanizmu do powstania listopadowego wtacznie. Lwów: Zakład Narodowy im. Ossolińskich.

Ujejski, Józef 1937: W stulecie „Irydiona”. Kultura i Nauka, ss. 231-247.

Vrtel-Wierczyński, Stefan 1912: Przyroda w warszawskim okeresie twórczości Zygmunta Krasińskiego. Lwów: nakładem c.k. Rady Szkolnej Krajowej: Gubrynowicz i Syn.

Vrtel-Wierczyński, Stefan 1914: Do dziejów satyry na Emigracji po r. 1831. Pamiętnik Literacki, ss. 188-205.

Vrtel-Wierczyński, Stefan 1916: „Rycerz Lud” Słowackiego. Pamiętnik Literacki, ss. 5-32.

Wasylewski, Stanisław (red.) 1909: Cieniom Juliusza Słowackiego. Ksiażka zbiorowa ucznión W szechnicy Lwowskiej. Lwów: Księgarnia i Skład Nut Gubrynowicza i Schmidta.

Werner, Richard Maria 1887a: Wiersz Uhlanda do Mickiewicza. Pamiętnik Towaryystwa Literackiego im. Adama Mickiewicza, R. 1, ss. 138-139.

Werner, Richard Maria 1887b: Wspomnienie Alfreda Meissnera o Mickiewiczu. Pamiętnik Towarzystwa Literackiego im. Adama Mickiewicza, R. 1, ss. 192-193.

Werner, Richard Maria 1891: Niemiecki nekrolog Mickiewicza. Pamiętnik Towaraystwa Literackiego im. Adama Mickiewicza, R. 5, ss. 201-202.

Werner, Richard Maria 1898: Parę uwag o motywie zasadniczym „Alpuhary”. Pamiętnik Towarsystwa Literackiego im. Adama Mickiewicza, R. 6, ss. 257-261.

Windakiewicz, Stanisław 1910: Badania źródtowe nad twórczościa Stowackiego. Kraków: nakładem autora. 
Windakiewicz, Stanisław 1914: Walter Scott i Lord Byron w odniesieniu do polskiej poezji romantycznej. Kraków: G. Gebethner i Spółka.

Windakiewicz, Stanisław 1918: Prolegomena do „Pana Tadeusz̨a”. Kraków: księgarnia G. Gebethnera i Spółki; Warszawa: Gebethner i Wolff.

Windakiewicz, Stanisław 1933: Próby i pomysły dramatyczne Mickiewicza. Pamietnik Literacki, R. 30, z. 1, ss. 61-69.

Windakiewicz, Stanisław 1935: Adam Mickiewicz. Życie i dzieła. Kraków: Gebethner i Wolff.

Windakiewicz, Stanisław 1937: Romantyzm w Polsce. Kraków: Gebethner i Wolff.

Wojciechowski, Konstanty 1900: Hrabia w „Panu Tadeuszu” a „Don Kichot”. Sprawozdanie Gimnazjum w Stryju za rok 1900.

Wojciechowski, Konstanty 1919a: Motywy „Wawerleya” W. Scotta w „Grażynie” i w „Konradzie Wallenrodzie”: Halban jako postać kierownicza. Pamiętnik Literacki, R. 17, ss. 289-301.

Wojciechowski, Konstanty 1919b: „Pan Tadeusz” Adama Mickiewicza a romans Waltera Scotta. Kraków: nakładem Akademii Umiejętności.

Zdziechowski, Marian 1912: Wirja Krasińskiego. Ze studiów nad literatura i filozofia polske. Kraków: S.A. Krzyżanowski.

Zdziechowski, Marian 1916: Mesjanizm polski a mesjanizm włoski. Kłosy Ukrainskie, nr 19-20.

Życzyński, Henryk 1920a: Estetyka Zygmunta Krasińskiego. Pamiętnik Literacki, R. $17 / 18$, ss. $56-92$.

Życzyński, Henryk 1920b: Pojęcie tragizmu u Słowackiego. Kurier Lwowski, R. 38, nr 89-91.

Życzyński, Henryk 1922a: Brodziniski i Mickiewicz. wobec „Laokoona” Lessinga. Lwów: nakładem Towarzystwa Naukowego.

Życzyński, Henryk 1922b: Idea państwowo-twórcza w ujęciu Słowackiego. Słowo Polskie, R. 28, nr 299.

Życzyński, Henryk 1923a: Apolliński i dionizyjski żywioł w poemacie Słowackiego W Szwajcarii”. Dziennik Cieszyńnki, nr 169

Życzyński, Henryk 1923b: Z estetyki Mickiewicza. Cieszyn: nakładem Księgarni „Kresy”

Życzyński, Henryk 1924a: Rozbiór koncertu Jankiela A. Mickiewicza. Miesięcznik Pedagogiczny, R. 33, ss. 168-185.

Życzyński, Henryk 1924b: Słowacki - Wyspiański a jutro narodu. Džiennik Cieszyński, nr 22. 
Życzyński, Henryk 1924c: Studia estetyczno-literackie. Cieszyn: nakładem Księgarni „Kresy”.

Życzyński, Henryk 1926: J. Słowackiego „Godzina myśli”. (Jej geneza i znaczenie w rozwoju twórczości). Pamiętnik Literacki 1925/1926, R. 22/23, ss. 241-251.

Życzyński, Henryk 1928: Kompozycja i styl „Dziadów” wileńskich. [W:] Ksiega pamiatkowa ku czici Stanisława Dobrzyckiego. Poznań, ss. 368379.

Życzyński, Henryk 1930: Charakterystyka poezji K. Brodzińskiego. Pamiętnik Lubelski, t. 1, ss. 215-239.

Życzyński, Henryk 1932: „Dzৃiady” drezdeńskie Mickiewicza w setnq rocznice: Lublin, Warszawa: Dom Książki Polskiej.

Życzyński, Henryk 1934a: Brodziński - teoretyk sielanki. Prad, R. 21, z. 12, ss. $224-233$.

Życzyński, Henryk 1934b: Mickiewicz w Odessie. Uwagi w związku z dyskusją zapoczątkowana przez D. Fiłosofowa. Głos Lubelski, nr 109-111.

Życzyński, Henryk 1934c: Mickiewicz w oświetleniu Odyńca. Pamiętnik Lubelski, t. 2 , ss. $24-44$.

Życzyński, Henryk 1935: Spór o Norwida. Prad, R. 22, t. 28, z. 4, ss. 205-210.

Życzyński, Henryk 1937: Norwida „Zwolon”. Prad, R. 24, t. 33, z. 2, ss. 115-126.

Życzyński, Henryk 1939: Autentyczność ks. Piotra. Prad, R. 26, z. 5/6, ss. 263-282.

\section{OPRACOWANIA}

Aleksandrowska, Elżbieta et al. (red.) 1969: Bibliografia literatury polskiej „Nowy Korbut”, t. 8: Romantyzm. Oprac. zespół pod kierownictwem Irminy Śliwińskiej i Stanisława Stupkiewicza. Warszawa: Państwowy Instytut Wydawniczy.

Aleksandrowska, Elżbieta et al. (red.) 1970-1983: Bibliografia literatury polskiej „Nowy Korbut”, t. 13-16: Literatura pozytywizmu i Młodej Polski. Oprac. zespół pod kierownictwem Zygmunta Szweykowskiego i Jarosława Maciejewskiego. Warszawa: Państwowy Instytut Wydawniczy. ISBN 83-06-00104-4.

Araszkiewicz, Feliks (red.) 1961: Juliusz Kleiner. Ksiega zbiorowa o życiu i działalności. Lublin: Wydawnictwo Towarzystwa Naukowego Katolickiego Uniwersytetu Lubelskiego.

Blüth, Rafał Marceli 1928: Niesprawiedliwa monografia. Polska Zbrojna nr 251, s. 5.

Całek, Anita 2012: Adam Mickiewicz - Juliusz Stowacki. Psychobiografia naukowa. Kraków: Wydawnictwo Uniwersytetu Jagiellońskiego. ISBN 978-83-233$-3248-0$. 


\section{Mariusz Chrostek}

Przełomowe osiągnięcia Iwowskich filologów w badaniach...

Chrostek, Mariusz 2016: Złote lata polonistyki lwowskiej (1919-1939). Rzeszów: Wydawnictwo Uniwersytetu Rzeszowskiego. ISBN 978-83-7996-274-7.

Chrzanowski, Ignacy 1917: Charakterystyka romantyzmu. (Dwa odczyty publiczne, wygłoszone we Lwowie w r. 1916). [W:] idem, Z epoki romantyzmu. Studia i sұkice. Kraków, ss. 1-69.

Dybiec, Julian 2000: Uniwersytet Jagielloński 1918-1939. Kraków: Wydawnictwo Polskiej Akademii Umiejętności.

Finkel, Ludwik; Starzyński, Stanisław 1894: Historia Uniwersytetu Lwowskiego, cz. I-II. Lwów.

Finkel, Ludwik; Chlamtacz, Marceli (oprac.) 1899: Kronika Uniwersytetu Lwowskiego, cz. I (1894/95-1897/98). Lwów.

Górski, Konrad 1961: Juliusz Kleiner jako historyk literatury. [W:] Juliusz Kleiner. Ksiega abiorowa o jyciu i džiałalności, red. Feliks Araszkiewicz. Lublin: Wydawnictwo Towarzystwa Naukowego Katolickiego Uniwersytetu Lubelskiego, ss. 11-38.

Hahn, Wiktor (oprac.) 1912: Kronika Uniwersytetu Lwowskiego, cz. II (1898/99_ 1909/10). Lwów.

Janion, Maria 1965: Rozwój marksistowskiej koncepcji romantyzmu w Polsce. [W:] Z problemów literatury polskiej XX wieku, red. Stefan Żółkiewski et al., t. 3: Literatura Polski Ludowej, red. tomu Alina Brodzka, Zbigniew Żabicki. Warszawa: Państwowy Instytut Wydawniczy, ss. 366- 398.

Janion, Maria 1986: Badania nad romantyzmem polskim. [W:] Roźwój wiedzy o literaturze polskiej po 1918 roku. Opracowal i wstępem opatrzył Janusz Maciejewski. Warszawa: Spółdzielnia Wydawnicza „Czytelnik”. ISBN 83-07-01340-2, ss. 116-147.

Kamiński, Leszek 1981: Romantyzm i polityka dwudziestolecia. [W:] Problemy polskiego romantyzmu. Seria trzecia. Praca zbiorowa pod red. Marii Żmigrodzkiej. Wrocław: Zakład Narodowy im. Ossolińskich. ISBN 83-04-00745-2, ss. 353-383.

Kawyn, Stefan 1967: Juliusz Kleiner (1886-1957). Roczniki Biblioteczne, R. XI, z. 1-2, ss. 47-54.

Kijas, Juliusz 1966: Dzieje Katedry Historii Literatury Polskiej UJ w okresie Stanisława Tarnowskiego (1871-1909). [W:] Drieje Katedry Historii Literatury Polskiej w Uniwersytecie Jagiellonskim. Zarys monograficzny, red. Tadeusz Ulewicz. Kraków: Wydawnictwo Literackie, ss. 111-163.

Kleiner, Juliusz 1912: rec. Tadeusz Grabowski, Juliusz stowacki. Jego śywot i dzieła na tle wspótczesnej epoki, t. 1-2. Kraków 1909-1912. Pamiętnik Literacki, z. 1, ss. 631-636. 
Korzeniewska, Ewa (red). 1963-1964: Stownik wspótczesnych pisarzy polskich, t. 1-3. Warszawa: Państwowe Wydawnictwo Naukowe.

Kridl, Manfred 1928: rec. Tadeusz Pini, Krasiński. Życie i twórczość. Poznań 1928, ss. 323. Pamiętnik Literacki R. XXV, z. 2, ss. 338-344.

Kulczycka-Saloni, Janina 1964: Piotr Chmielowski (1848-1904). [W:] Z diiejów polonistyki warszawskiej, red. Janina Kulczycka-Saloni et al. Warszawa: Państwowe Wydawnictwo Naukowe, ss. 209-231.

Kulczycka-Saloni, Janina et al. (red.) 1964: Z dziejów polonistyki warszawskiej. Warszawa: Państwowe Wydawnictwo Naukowe.

Libera, Zdzisław 1964: Józef Ujejski (1883-1937). [W:] Z dziejów polonistyki warszawskiej, red. Janina Kulczycka-Saloni et al. Warszawa: Państwowe Wydawnictwo Naukowe, ss. 281-295.

Maciejewski, Jarosław 1992: Drieje poznańskiej polonistyki uniwersyteckiej 1842-1988. Poznań: Wydawnictwo Naukowe Uniwersytetu im. Adama Mickiewicza. ISBN 83-232-0415-2.

Markiewicz, Henryk 1977: Słowo wstępne. [W:] Stanisław Tarnowski, O literaturze polskiej XIX wieku, wybór i opracowanie Henryk Markiewicz. Warszawa: Państwowe Wydawnictwo Naukowe (Biblioteka Filologii Polskiej. Seria B: Literaturoznawstwo pod red. Tadeusza Ulewicza), ss. 5-39.

Markiewicz, Henryk 1987: Nauka o literaturze. [W:] Historia nanki polskiej, red. Bogdan Suchodolski, t. IV: 1863-1918, cæ. III, red. tomu Zofia SkubałaTokarska. Wrocław: Zakład Narodowy im. Ossolińskich, Wydawnictwo Polskiej Akademii Nauk. ISBN 83-04-02800-X, ss. 703-725.

Markiewicz, Henryk 2000: Juliusz Kleiner (1886-1857). [W:] Uniwersytet Jagielloński. Ztota Ksiega Wydziatu Filologicznego, red. J. Michalik, W. Walecki. Kraków: Księgarnia Akademicka. ISBN 83-7188-298-X; 978-83-7188-298-2 (seria Złote Księgi Uniwersytetu Jagiellońskiego), ss. 343-353.

Maślanka, Julian 1985: Słowo wstępne. [W:] Stanisław Pigoń, Popržez stulecia. Studia z dziejów literatury i kultury, wybór i opracowanie Julian Maślanka. Warszawa: Państwowe Wydawnictwo Naukowe. ISBN 83-01-04990-1 (Biblioteka Filologii Polskiej. Seria B: Literaturoznawstwo pod red. Tadeusza Ulewicza), ss. 6-28.

Matracki, Zygmunt 1975: Biografistyka literacka Kleinera. [W:] Biografia-geografiakultura literacka, red. Jerzy Ziomek. Warszawa: Wydawnictwo Instytutu Badań Literackich PAN (Z Dziejów Form Artystycznych w Literaturze Polskiej, t. XL), ss. 139-169.

Mikulski, Tadeusz 1976: Miniatury krytyczne, przedmowa Wiktor Weintraub. Warszawa Państwowy Instytut Wydawniczy. 
Skwarczyńska, Stefania 1961: Juliusz Kleiner jako metodolog i teoretyk literatury. [W:] Juliusz Kleiner. Ksiega zbiorowa o życiu i działalności, red. Feliks Araszkiewicz. Lublin: Wydawnictwo Towarzystwa Naukowego Katolickiego Uniwersytetu Lubelskiego, ss. 39-95.

Starnawski, Jerzy (red) 1994-2009: Stownik badaczy literatury polskiej, t. 1-10. Lódź: Łódzkie Towarzystwo Naukowe. ISBN 978-83-60655-23-8.

Starnawski, Jerzy 1997a: Sylwetki lwowskich historyków literatury. Łódź: Wydawnictwo Uniwersytetu Lódzkiego. ISBN 83-7171-037-2.

Starnawski, Jerzy 1997b: Sylwetki wilenskich historyków literatury. Bydgoszcz: Towarzystwo Miłośników Wilna i Ziemi Wileńskiej. Oddział w Bydgoszczy. ISBN 83-907732-3-6 (Biblioteka Wileńskich Rozmaitości, seria B, nr 15).

Starnawski, Jerzy 1999: Juliusz Kleiner jako badacz i wydawca Słowackiego. [W:] Juliusz Kleiner, Juliusz Stowacki. Dzieje twórczości, t. 1: Twórczość mtodzieńcza, wstęp i oprac. Jerzy Starnawski. Kraków: Wydawnictwo Literackie. ISBN 83-08-03423-3, ss. 5-34.

Starnawski, Jerzy 2009: Biegeleisen Henryk. [W:] Stownik badaczy literatury polskiej, t. 10, red. Jerzy Starnawski. Łódź: Lódzkie Towarzystwo Naukowe. ISBN 978-83-60655-23-8, ss. 27-32.

Ulewicz, Tadeusz (red.) 1966: Drieje Katedry Historii Literatury Polskiej w Uniwersytecie Jagiellońskim. Zarys monograficzny. Kraków: Wydawnictwo Literackie.

Waśko, Andrzej 2014: Wstęp. [W:] Stanisław Tarnowski, Zygmunt Krasiński. Kraków: Ośrodek Myśli Politycznej. ISBN 978-83-62628-50-6, ss. VII-XXVI.

Wyka, Kazimierz 1951: Stan badań i potrzeby nauki o literaturze romantyzmu polskiego. [W:] O sytuacii w historii literatury polskiej. Wybór referatów wygtoszonych na zjeździe polonistów w dniach od 8 do 12 maja 1950 r., red. Jan Baculewski. Warszawa: Państwowy Instytut Wydawniczy, ss. 186-211. 